1980

\title{
Papers of the Archaeology of the Texas Coast
}

\section{Lynn Highley}

Center for Archaeological Research

Thomas R. Hester

Center for Archaeological Research

Follow this and additional works at: https://scholarworks.sfasu.edu/ita

Part of the American Material Culture Commons, Archaeological Anthropology Commons, Environmental Studies Commons, Other American Studies Commons, Other Arts and Humanities Commons, Other History of Art, Architecture, and Archaeology Commons, and the United States History Commons

Tell us how this article helped you.

This Article is brought to you for free and open access by the Center for Regional Heritage Research at SFA ScholarWorks. It has been accepted for inclusion in Index of Texas Archaeology: Open Access Gray Literature from the Lone Star State by an authorized editor of SFA ScholarWorks. For more information, please contact cdsscholarworks@sfasu.edu. 


\section{Papers of the Archaeology of the Texas Coast}

Creative Commons License

(c) (i) (9)

This work is licensed under a Creative Commons Attribution-NonCommercial 4.0 International License 
THE TEXAS COAST

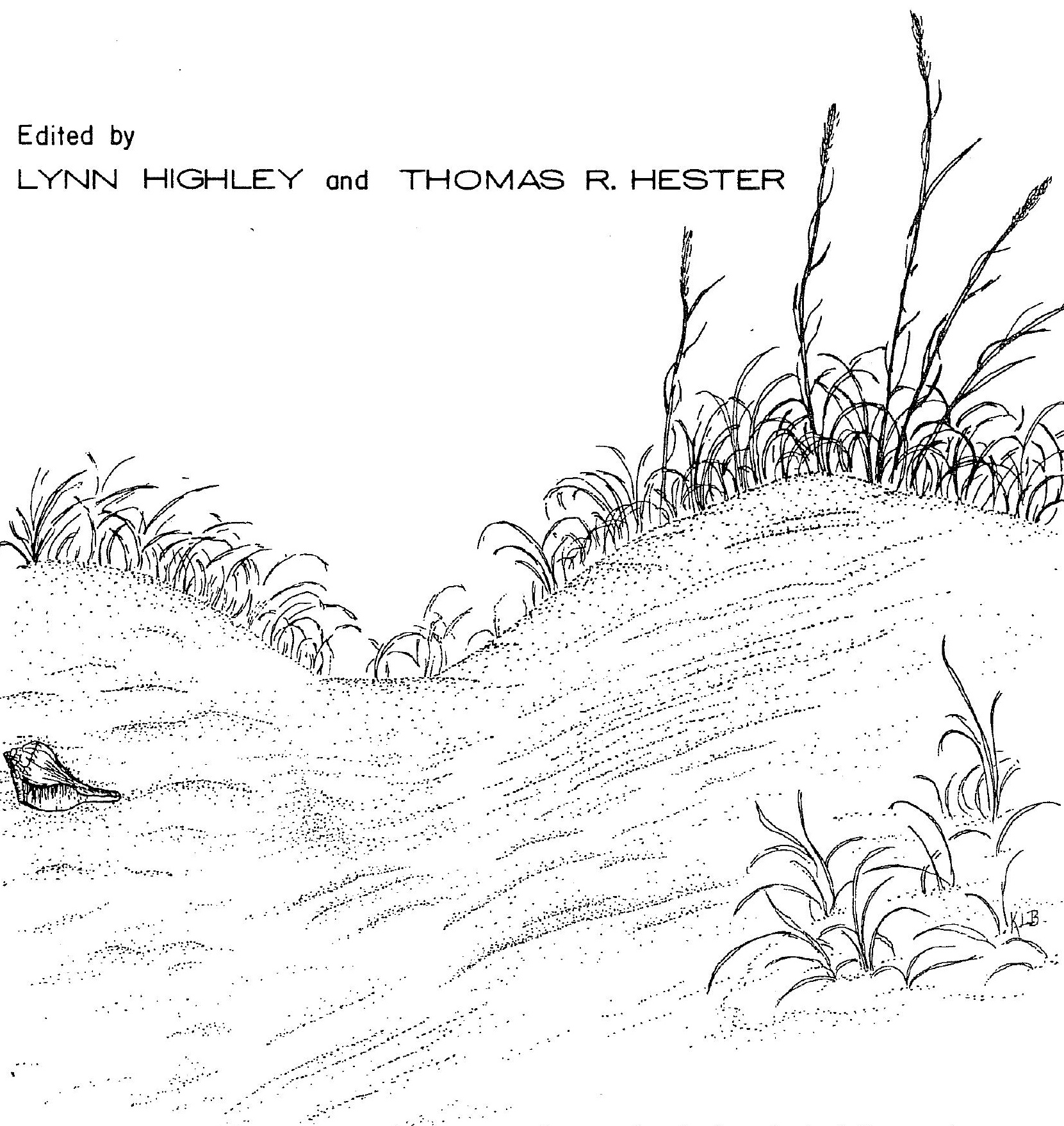

Center for Archaeological Research The University of Texas at San Antonio SPECIAL REPORT, NO.II 


\section{Center for Archaeological Research \\ The University of Texas at San Antonio}

78285

Thomas R. Hester, Director

\section{Special Reports}

Publications dealing with the archaeology of Texas and Mesoamerica.

No. 1 (1975) Some Aspects of Late Prehistoric and Protohistoric Archaeology in Southern Texas. By Thomas R. Hester and T. C. Hill, Jur. Photocopy reprints available. $\$ 2.00+.11$ tax for Texas residents.

No. 2 (1976) The Texas Archaic: A Symposium. Edited by Thomas R. Hester. Photocopy reprints available. $\$ 4.00+.22$ tax for Texas residents.

No. 3 (1976) Papers on Paleo-Indian Archaeology in Texas. Papers by $T$. R. Hester and W. W. Birmingham. Photocopy reprints available. $\$ 2.00+.11$ tax for Texas residents.

No. 4 (1976) Maya Lithic Studies: Papers from the 1976 Belize Field Symposium. Edited by $T$. R. Hester and Norman Hammond. Reprinted 1979. $\$ 9.00+.50$ tax for Texas residents.

No. 5 (1977) Hop Hill: Culture and Climatic Change in Central Texas. By Joel Gunn and Royce Mahula. Out of print.

No. 6 (1978) Volume 1; Background to the Archaeology of Chaparrosa Ranch, Southern Texas. Studies in the Archaeology of Chaparrosa Ranch. By Thomas R. Hester. $\$ 4.00+.22$ tax for Texas residents.

Volume 2; The Mariposa Site: A Late Prehistoric Site on the Rio Grande Plain of Texas. Studies in the Archaeology of Chaparrosa Ranch. By John Montgomery. $\$ 8.00+.44$ tax for Texas residents.

No. 7

The Study of Biosilica: Reconstructing the Paleoenvironment of the Central Coastal Plain of Texas. By Ralph L. Robinson. In press.

No. 8 (1979) The Lithic Artifacts of Indians at the Spanish Colonial Missions, San Antonio, Texas. By Daniel E. Fox. $\$ 5.00+$ .28 tax for Texas residents.

No. 9 (1980) Papers on the Prehistory of Northeastern Mexico and Texas: Edited by Jeremiah F. Epstein, Thomas R. Hester, and Carol Graves. $\$ 7.00+.39$ tax for Texas residents.

No. 10 Excavations at the Alamo Shrine (San Antonio de Valero), 1977. By Jack D. Eaton. In press.

No. 11 (1980) Papers on the Archaeology of the Texas Coast. Edited by Lynn Highley and Thomas R. Hester. $\$ 6.00+.33$ tax for Texas residents. 


\title{
PAPERS ON THE ARCHAEOLOGY OF THE TEXAS COAST
}

\author{
edited by \\ Lynn Highley and Thomas R. Hester
}

Center for Archaeological Research The University of Texas at San Antonio Special Report, No. 11 
TABLE OF CONTENTS

Page

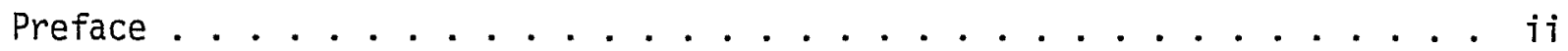

A Survey of Paleo-Indian Archaeological Remains Along the Texas Coast

(Thomas R. Hester).................. 1

41 HR 206, A Major Site in Harris County, Texas (L. W. Patterson) . . . . . 13

A Preliminary Study of the Shel1 Ornaments of the Texas Coast Between Galveston Bay and the Nueces River (Beverly Janota) . . . . . . . 29

Notes on Conch She11 Adze Technology, Texas Coast (E. R. Mokry, Jr.). . . . 51

Archaeological Materials from the Alazan Bay Area, Kleberg County, Texas (Lynn Highley). . ................. 61

The La Paloma Mammoth Site, Kenedy County, Texas (Raymond W. Suhm) with notes on the archaeology (Thomas R. Hester). . . . . . . 79

Changing Salinity in Baffin Bay, Texas, and its Possible Effects on Prehistoric Occupation (Thomas R. Hester) . . . . . . . . 105 


\section{PREFACE}

The papers published in this volume represent contributions from professional archaeologists, avocational archaeologists, and students. Many aspects of coastal archaeology are unknown, and there is a great need for data-oriented papers, site reports, reviews of specific aboriginal technologies, and for other papers dealing with certain facets of the prehistoric and historic archaeology of the coastat zone.

We hope that this volume will be followed by others also concerned with the archaeology of the Texas coast and adjacent or related coastal areas. We urge you to send papers or ideas for contributions to such future volumes to the Center.

The cover for this volume was designed by Kathy Bareiss of the Center. The manuscript was typed by Elizabeth Goode, Mary Lou Ellis, and Frieda Barefield.

Lynn Highley

Thomas R. Hester

October 1980 


\title{
A SURVEY OF PALEO-INDIAN ARCHAEOLOGICAL REMAINS
}

\author{
ALONG THE TEXAS COAST
}

Thomas R. Hester

\section{Introduction}

Although there has been a tremendous increase in archaeological activity along the Texas Gulf coast in the past few years, there remains very little in the literature pertaining to the earliest human occupations of the region. As a small step toward remedying this situation, I have attempted in this brief paper to compile many of the scattered occurrences of Paleo-Indian sites and materials in the coastal zone. No substantive contributions are offered here in the realms of paleoenvironment or geomorphology (the reader is referred to the detailed studies published by Coastal Environments [1977]), and I am of the opinion. that our almost nonexistent data base for this period also precludes any speculation regarding subsistence orientations, settlement patterns or other behavioral aspects of these early populations. Thus, the goal of this paper is to call attention to known Paleo-Indian manifestations in the coastal strip, a narrow 55-75 mile wide band characterized by Quaternary formations known as the Houston group (cf。Oetking 1959), along the Texas side of the Gulf of Mexico (Fig. 1).

I shall not attempt to review either the archaeological background or the environmental characteristics of the coastal zone; the reader may consult Aten (1971), Briggs (1971), Campbe11 (1960), LeB1anc and Hodgson (1959), Scurlock, Lynn and Ray (1974), and Coastal Environments (1977), among others, for data of this sort. Also of relevance are studies of Paleo-Indian occupations along the Gulf coast of Louisiana, especially the papers of Gagliano (1963), Gagliano and Gregory (1964) and Gibson and Miller (1973)。

Very little is known about the coastal zone of 10,000-12,000 years ago; Aten (1971) is of the opinion that a tall-grass prairie vegetational pattern was dominant, with moisture exceeding that of today. It is, however, firmly established that there were significant changes in sea level during the Pleistocene, and into the early Holocene (this problem has been discussed at length for the Atlantic coast; cf. Bullen 1969; Emery and Edwards 1966; Solecki 1961; Coastal Environments 1977).

Most students of the problem believe that the late Pleistocene shoreline was at a considerably lower elevation than the modern one, and that the present configuration of the coastal strip was not achieved until 3000-4000 years ago. For example, LeBlanc and Hodgson (1959:58) have written:

During the last Pleistocene glacial stage when sea level was lowered approximately 450 feet, the coastal Texas streams deeply entrenched their valleys and the Gulf shoreline was probably 50 to 140 miles seaward of the present shoreline.

At least nine major Texas river systems of the late Pleistocene cut valleys out to the Gulf. Given the presence of major valley systems and a shoreline 


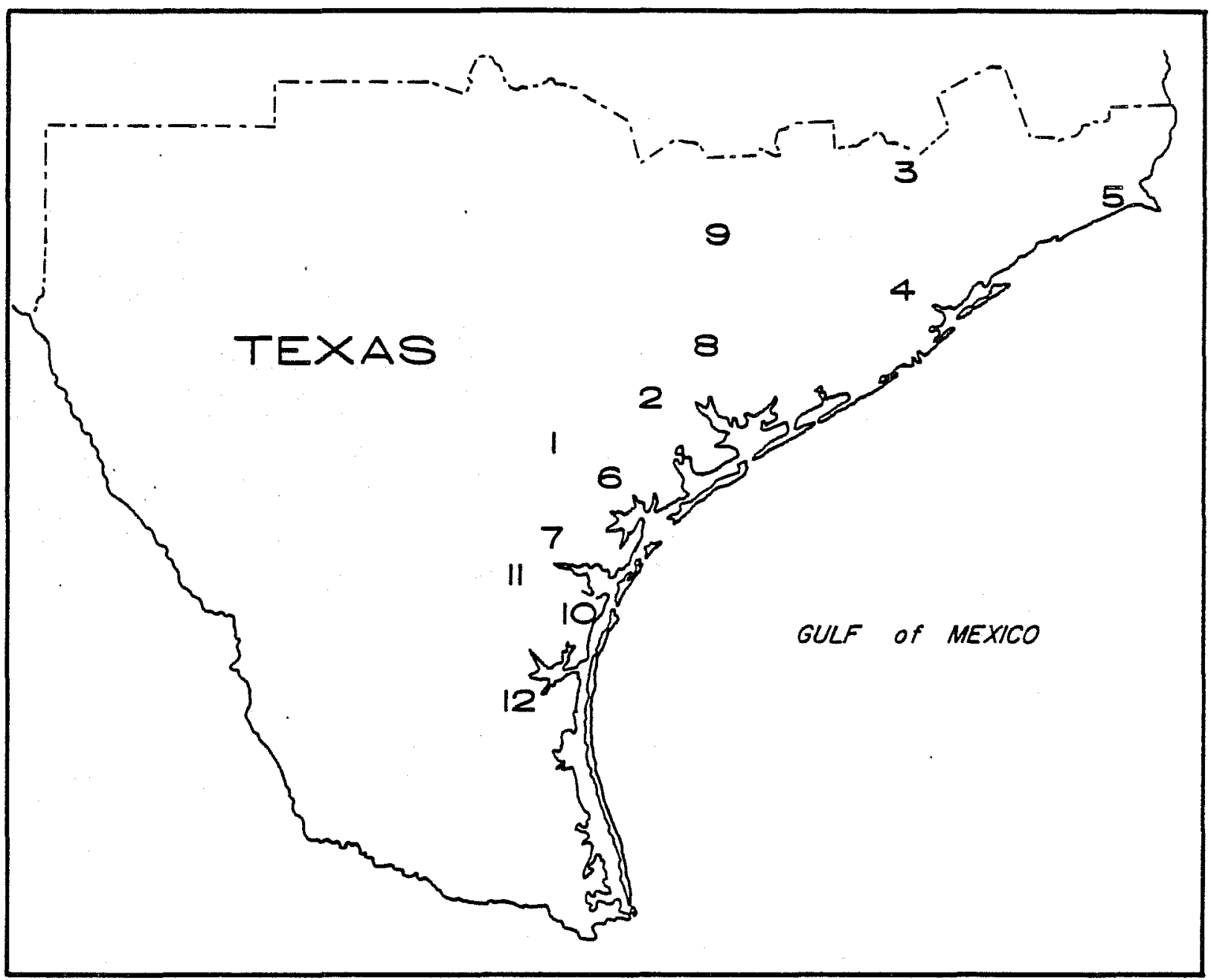

Figure 1. Location of Paleo-Indian Sites Along the Texas Coast.

1 Buckner Ranch

2 Victoria and Goliad Counties

(41 VT 15, J-2, Miller, Willeke, 41 GD 30, Morhiss)

3 Harris County (Addicks, Galena)

4 Damon Mound Area (41 BO 21, 41 BO 25)

5 McFaddin Beach
6 St. Nicolas and Willow Lakes

7 Jackson County (41 JK 147)

8 San Patricio County (41 SP 99)

9 Colorado County (4T CD 39)

10 Oso Creek Sites

11 Petronilla Creek

12 Kenedy County (La Paloma) 
that extended up to 140 miles from the present one, it is obvious that we will probably always have to deal with a partial sample of the possible Paleo-Indian data, and that most such data are going to be forever inaccessible.

\section{The Archaeological Evidence}

As far as I know, only two possible Paleo-Indian occupational localities have been documented within the coastal zone.* One of these is Buckner Ranch in Bee County, reported by Sellards (1940). At a depth of about 15 feet in terrace deposits at Site 1 at Buckner Ranch, Sellards excavated a number of artifacts, burned rocks (some hearth-like clusters) and associated fossil mammals. A varied series of projectile points were recovered, including specimens resembling Plainview, Scottsbluff. Angostura and Folsom. Also present were two side-notched points. The mixture of types has suggested to some that the materials occurred in a secondary (redeposited) context. However, Sellards carefully plotted the vertical and horizontal positions of all artifacts and fossils (ibid.:Fig. 4) and made the following comments:

The ground plan... shows that the artifacts and associated man-made objects at Site 1 were not uniform1y distributed in the area excavated but tend to occur in groups either in camp sites, hearths, or at the place of chipping (Sellards 1940:1638).

Sellards also observed the close association of a core and several flakes detached from it. It may well be that some specimens in the Site 1 "lower horizon" had been stream-carried. On the other hand, Sellards' careful recording and observations make it clear that much of the material was in situ. I would suggest that it was a late Pleistocene-early Holocene campsite which had been repeatedly occupied by a series of Paleo-Indian groups.

A second site of Paleo-Indian age is the Johnston site (41 VT 15) in Victoria County (Birmingham and Hester 1976). Gully action has exposed a deeply buried occupation zone in a terrace of the Guadalupe River. Several Clear Fork tools have been found in place in the zone; these are of the bifacial variety linked to the Late Paleo-Indian period by Epstein (1969) and Hester (1978). Collected from the gully floor, immediately below the zone, were several Paleo-Indian points. These are presumed to have eroded from this buried stratum. The specimens are primarily of the Golondrina and Plainview types. However, a Clovis point and several shouldered lanceolate points were also found. Test excavations at the site have revealed a series of Archaic occupations in the 13 feet of alluvium overlying the deeply buried zone.

Scattered throughout the coastal zone are numerous surface occurrences of PaleoIndian artifacts. I have selected a number of significant examples and these are discussed below.

* A third site, Berger Bluff (41 GD 30), has been excavated by The University of Texas at San Antonio, directed by D. and K. Brown, along Coleto Creek, Goliad County. A radiocarbon date of ca. 9600 B.C. has been obtained from a deeply buried hearth at the site. 
UPPER COAST. Wheat (1953) noted several Paleo-Indian projectile points in his survey of the Addicks Reservoir basin. These included Plainview (ibid.:P1. 39, f), a lanceolate form, Scottsbluf́f (Wheat 1953:P1. 38,a,b) and a possible clovis fragment (ibid.:240).

A Clovis point has been reported from the Galena site in Harris County (Ray Ring collection, Texas Archeological Research Laboratory, Austin; see also Suhm, Krieger and Jelks 1954:121). Plainview and Golondrina points (as we11 as some examples of Meserve) have been found on the upper coast, particularly in Harris County (cf. Suhm, Krieger and Jelks 1954:121) and in the Damon Mound area of Brazoria County (41 B0 21 and 41 BO 25; Cole and McMichael 1968). Lanceolate points resembling Angostura are known from several Harris County sites, including $41 \mathrm{HR} 1$ and 41 HR 50. Scottsblufo points were collected from the Galena site (Ray Ring collection, Texas Archeological Research Laboratory, Austin) and from the vicinity of Red Bluff in southeast Harris County (Alan Duke, personal communication).

More recentiy, a locality that has produced numerous surface finds of PaleoIndian points has been reported from McFaddin Beach in Jefferson County (Long 1977). The Paleo-Indian artifacts have been collected from wave-eroded areas along the beach; they include examples of clovis (and other fluted specimens resembling Clovis), Scottsblufo and San Patrice, and a variety of probable Late Paleo-Indian poinis (lanceolate and stemmed or notched forms) similar to forms reported from the southeastern United States. There are also examples of the shouldered lanceolate projectile point form mentioned earlier. Flake and blade tools, perhaps of Paleo-Indian age, are reported. In addition, a number of Archaic artifacts have also come from surface contexts at this locality.

A variety of Pleistocene and post-Pleistocene fauna are briefly noted by Long $(1977: 6,7)$ and he reports a radiocarbon date of $9150 \pm 750 \mathrm{~B}$.C. from a piece of elephant tusk (either mammoth or mastodon) found at McFaddin Beach. At this writing, there is not yet any clear-cut evidence for the association of the Paleo-Indian materials and Pleistocene fauna, but further studies are underway (Curtis Tunne11, personal communication) and the results are awaited with great interest.

CENTRAL COAST. Abundant evidence of early occupations is to be found on the central coast, particularly in Victoria County. E. H. Schmiedlin and W. W. Birmingham (Victoria) have recorded a number of sites in that county, and several of these have yielded early point styles. These include the J-2 Ranch site and the Miller site. The latter site (41 VT 5) was buried in a high terrace rimming the Guadalupe River valley, about 40 miles upstream from San Antonio Bay. A wide array of artifacts have been obtained from surface contexts. Most of the site was originally buried in a one-foot stratum overlying a gravel formation. Most, if not all, of the site has been destroyed by gravel-quarrying operations. Artifacts are consistently heavily patinated Late Paleo-Indian and Pre-Archaic forms, including Plainview, Golondrina, Angostura, shouldered lanceolate, Gower, Bell and "Early Triangular" (cf. Hester 1971). Other artifacts include bifacial clear Fork tools, Guadalupe tools and pebble-sized core-choppers. 
Also in Victoria County is the deep, multi-component Willeke site. Near the base of its 6-meter deposit, single examples of Gower and Golondrina have been found (Fox and Hester 1976). It is hoped that additional excavations will be carried out at the site in the future. It has the potential for yielding a long chronological sequence for this portion of the coastal zone.

Other occurrences of Paleo-Indian artifacts in the central coastal area can be summarized as follows:

Clovis: Buckner Ranch, Bee County (described earlier); Calhoun County (Suhm, Krieger and Jelks 1954:P1. 85,Q); San Patricio County, near Rockport (R. B. Worthington Collection, Texas Archeological Research Laboratory); and Victoria County, Johnston site (Birmingham and Hester 1976).

Folsom: Except for the Folsom specimen from Buckner Ranch, Bee County (described earlier in the paper), I am not aware of other clearly-documented examples from this region.

Plainview and Golondrina: Both forms occur commonly. Buckner Ranch, Bee County (described earlier); St. Nicolas and Willow Lakes sites in Refugio County (Enlow and Campbe11 1955); a number of sites in Victoria County (mentioned above), including Morhiss (Suhm, Krieger and Jelks 1954:P1. 116,E); and 41 SP 99, San Patricio County (Holliday and Grombacher n.d.:Fig. 3,b).

Angostura and other lanceolate forms: Again, these Late Paleo-Indian styles are found frequently. Sites include Buckner Ranch (Bee County) and several sites in Victoria County; Refugio County (St. Nicolas and Willow Lakes area; Enlow and Campbel1 1955); 41 SP 99 in San Patricio County (Holliday and Grombacher n.d.:Fig. 3,i); and 41 JK 146, along the Navidad River in Jackson County (Birmingham, Schmied1 in and Hester 1976).

Scottsbluff: Several have been documented by Hester and Hill (1971). Scattered examples are known from: Buckner Ranch, Bee County; several Victoria County sites and localities; 41 CD 39 in Colorado County; near Berclair in Goliad County; and 41 SP 99, San Patricio County (Holliday and Grombacher n.d.:Fig. 3,f).

LOWER COAST. An area of particular importance is the Oso Creek drainage, a major stream south of Corpus Christi. Numerous prehistoric and historic occupation loci have been documented along the 0so, most dating from Archaic and Late Prehistoric times (Patterson and Ford 1974; Hester notes). However, a series of Paleo-Indian projectile points are known from the locality and several occurrences of elephant remains (primarily mammoth) have been reported. Many examples of the latter have been recorded by $W$. Armstrong Price (Corpus Christi); however, a number of the fossil elephant materials date to the middle Pleistocene.

Price has told me of a site on upper Oso Creek where he and Kirk Bryan observed elephant skeletal remains in the 1940s. Flint objects in apparent association with those remains were thought to be derived, via soil cracks, from overlying Holocene (presumably Archaic) occupations. In 1954, A. D. Krieger and E. H. Sellards visited another locality on the 0so, in the vicinity of Mud Bridge. 
On the T. M. Bertlet property, they observed eroded and scattered mammoth remains. Near one of the mammoth teeth lay the basal fragment of a lanceolate point, somewhat resembling Golondrina. A similar situation has been reported to me by Mrs. Elwood Hess (Corpus Christi). She discovered a long, pointed bone artifact, in a surface context, in close proximity to eroding elephant remains. There is, of course, no clear association, but the specimen does resemble the large bone artifacts found at some Clovis period sites (cf. Sellards 1952 for examples from Blackwater Draw, New Mexico).

Occurrences of scattered Paleo-Indian points (all from eroded surface sites) in the Oso drainage include the following: a Folsom point collected by Elwood Hess near Flour Bluff (Hester 1970), a Folsom-like fluted specimen found by Jerry Bauman (Corpus Christi) at his site B-10 and a series of fragmentary, possible Late Paleo-Indian points reported by Stanton and Hester (1968).

Petronilla Creek, in western Nueces County, runs almost parallel to the Oso Creek system. Patterson and Ford (1974:43) have reported site 41 NU 110, on the upper part of Petronilla Creek. This eroded open campsite has yielded several PaleoIndian projectile points, including Angostura (three specimens), a perforator made on an Angostura and the basal fragment of a Scottsblufi. This latter specimen fits morphologically within the group of Scottsblufo points described for the coastal plain by Hester and Hi17 (1971). Also found at 41 NU 110 were a number of Archaic dart points, artifacts of shell and a ground stone plummet.

Of possible significance to Paleo-Indian studies on the lower coast is the discovery of several mammoth skeletons in alluvial deposits at the La Paloma locality in Kenedy County. Raymond Suhm (Texas A\&I University) has been excavating these remains, buried at depths of four to six feet in what Suhm terms the "ancestral Palo Blanco River." Although no evidence of human association had been uncovered at the time this paper was prepared, Suhm has obtained four radiocarbon dates of ca. 6130-7880 B.C., which, if correct, would indicate the very late survival of mammoth populations on the coastal plain (Suhm 1978).

\section{Concluding Remarks}

The purpose of this overview has been to illustrate the nature and variety of Paleo-Indian cultural remains in the coastal zone of Texas. The data assembled here demonstrates man's presence on the coast at least as early as Clovis times (ca. 9,200 B.C.). While there are few recorded clovis or Folsom artifacts in the region, a number of projectile point types assignable to late Paleo-Indian times (Plainview, Golondrina, Angostura, Scottsbluff) occur with surprising frequency. Continuing distributional studies will no doubt amplify the sample discussed here, and, hopefully, reveal meaningful patterns of Paleo-Indian utilization of the littoral. Demonstrable associations of artifacts and late Pleistocene fauna occur only at the Buckner Ranch locality reported by Sellards (1940). The excavation techniques used at Buckner Ranch in 19381939 perhaps obscured vertical relationships. However, the careful horizontal recording done at the time of those excavations strongly suggests that in situ occupations were present. I do not know what the situation is today in the vicinity of the Buckner sites in Bee County; one would hope, however, that further excavations will eventually be carried out in order to clarify the archaeological picture. The sites certainly seem to hold great potential for 
Paleo-Indian research, as well as for geomorphological and paleoenvironmental studies.

There are several other sites in the coastal zone which also hold great promise for producing information on early man. The Johnston site in Victoria County (Birmingham and Hester 1976) is one of these. Excavations in the thick terrace deposits at that site are needed to place the early materials in context. The Willeke site, also in Victoria County, has deep deposits containing abundant cultural debris. A controlled test pit by Victoria amateur archaeologists revealed 4-6 meters of Archaic materials, with late Paleo-Indian and Pre-Archaic artifacts near the base. The maximum depth of human occupation was apparently never reached. Future excavations are planned, and these should help to elucidate the poorly known chronological framework of that area (cf. Fox and Hester 1976).

There are, of course, a myriad of problems that need to be investigated in the development of late Pleistocene research along the coast. Much of the area is still inadequately known geologically; that is, the kinds of geomorphological and paleoenvironmental interpretations needed by archaeologists are lacking. We know, for example, that there have been changes in sea level, and that sea level has risen substantially in the Holocene. A good many PaleoIndian sites must lie submerged off shore. But, what is known about the development of those drainage systems--such as the San Antonio, Guadalupe, Brazos and Nueces Rivers--which are sti11 accessible in large part to archaeological research? Geologist Rex Wayland (personal communication) of Corpus Christi believes that as late as 5000 B.C., the Nueces River of the lower coast was a much larger stream system than at present. He is also of the opinion that the Oso drainage was a highly significant and active system as late as 8000 B.C. Similarly, there is abundant evidence that the mouths of the streams were altered by rising sea level (Coastal Environments 1977). As W. Armstrong Price has written (letter to T. R. Hester, November 24, 1969): "Corpus Christi Bay was enlarged to its 10-mile width as the sea rose. There is a submerged terrace at about -20 feet, but whether level or sloping gulfward I do not know."

Has the changing character of these stream valleys and bays obliterated much of the evidence of early man along the coast? Certainly many occupational loci and ki11-sites were submerged; others were probably eroded and redeposited. With the succession of floodplains and periods of terrace formation in many of the drainages, many of the early sites must have been deeply buried under alluvial mantles. (such as the Johnston and Willeke sites). Sellards (1941:2008) has noted that "man has been present in Texas through at least three stages of terrace building by the streams . . . the rivers present an impressive demonstration of work accomplished during the time that man has inhabited the region."

Undoubtedly the key to obtaining more data on the Paleo-Indian of the Texas coast is knowing where to 10ok. Recent decades have seen coastal archaeologists concentrating on Archaic and Late Prehistoric manifestations, found in locales which are quite new in geological terms. Geomorphological research will no doubt be of great value in delimiting those formations of sufficient antiquity to contain the remains of early occupations. The publications of W. Armstrong Price (cf. Price 1958) and the volume published by Coastal Environments (1977) on the lower coast will also be of assistance to archaeologists working in that sector. 
However, the gaps in our archaeological data base are as severe as those in the areas of geomorphology and paleoenvironment. Studies of artifact distribution seem to be no longer in vogue, yet the essential research leads that we will need in order to accelerate Paleo-Indian investigations on the coast will have to rely heavily on such work. I would strongly urge amateur archaeologists in the coastal area to publish occurrences of Paleo-Indian artifacts in the various state and regional archaeological publications. I would also urge those professional archaeologists who work on the coast--often in problem-oriented salvage programs--to take the time to examine local artifact collections and to record (at least in accessible institutional files) data on early man sites and materials. Perhaps it is the shift in archaeological trends; or the pressing demands of contract research, but it seems to me that some professional colleagues tend to ignore the resources available through the examination of private collections and the materials and records of amateur archaeologists. The above statements are not intended as critical; certainly there is nothing wrong with a rigorously designed and stringently executed research program concentrating on a particular site or the impact of a local flood-control project. However, one need only to look back at A. D. Krieger's classic study, Culture Complexes and chronology in Northern Texas--compiled from years of contacts with collectors and amateurs, and the analysis (or re-analysis) of previously-excavated collections--to see the value of maintaining a broad data-gathering perspective in the course of conducting research. My concluding points are these: (1) there is a great need for more geomorphological and paleoenvironmental data; unless a professional archaeologist finds the funding for a major late Pleistocene research project on the Texas coast, we will have to await the results of such studies by scientists in other disciplines; (2) amateur archaeologists must work more actively in recording known Paleo-Indian sites and artifacts, and occurrences of late Pleistocene fauna; it is probably the amateur with his/her knowledge of the local topography, who will provide the leads necessary for major Paleo-Indian discoveries on the coast; the work of W. W. Birmingham and E. H. Schmiedlin on the central coast and Lee Patterson and Alan Duke on the upper coast serve as examples; (3) professional archaeologists also need to be more active in terms of examining local collections, following up reports of fossil occurrences and, hopefully, beginning to formulate plans for investigations of this badly neglected phase of human occupation on the Texas coast.

\section{Acknowledgments}

I would like to thank the following persons for their help and assistance during the preparation of this paper: Alan R. Duke (Pasadena, Texas), Leland W. Patterson (Houston, Texas) and Brent Smith (formerly of Houston, Texas). 


\section{REFERENCES CITED}

Aten, L. E.

1971 A Review and Synthesis of the Archeology of the Upper Texas Coast. Paper presented at the 74th annual meeting of the Texas Academy of Science, Nacogdoches.

Birmingham, W. W. and T. R. Hester

1976 Late Pleistocene Archaeological Remains From the JohnstonHeller Site, Texas Coastal Plain. In Papers on Paleo-Indian Archaeology in Texas: 1:15-33. Center for Archaeological Research, The University of Texas at San Antonio, Special Report 3.

Birmingham, W. W., E. H. Schmied Tin and T. R. Hester

1976 Archaeology at the Wells Site (41 JK 146), Jackson County, Texas. La Tierra 3(4):29-33.

Briggs, A. K.

1971 Archeological Resources in the Texas Coastal Lowlands and Littoral. Texas Historical Survey Committee and Texas Water Development Board, Austin.

Bullen, R. P.

1969 Further Comments on Emery and Edwards "Archeological Potential of the Atlantic She1f". American Antiquity 34(3):331-332.

Campbe11, T. N.

1960 Archeology of the Central and Southern Sections of the Texas Coast. Bulletin of the Texas Archeological Society 29:145-175.

Coastal Environments, Inc.

1977 Cultural Resources Evaluation of the Northern Gulf of Mexico Continental Shelf, Volume 1. Prehistoric Cultural Resource Potential. Cultural Resource Management Studies, National Park Service, Washington.

Cole, B. and J. McMichael

1968 Archeological Investigations in the Damon Mound Area, Brazoria County, Texas. Manuscript on file, Texas Archeological Research Laboratory, Austin. 
Emery, K. O. and R. L. Edwards

1966 Archaeological Potential of the Atlantic Continental Shelf. American Antiquity 31(5):733-737.

Enlow, D. H. and T. N. Campbel1

1955 Some Paleo-Indian Projectile Points from the Southeastern Periphery of the Great Plains. Panhandle-Plains Historical Review 28:29-37.

Epstein, J. F.

1969 The San Isidro Site, An Early Man Campsite in Nuevo Leon, Mexico. Department of Anthropology, University of Texas at Austin, Anthropology Series 7.

Fox, A. A. and T. R. Hester

1976 An Archaeological Survey of Coleto Creek, Victoria and Goliad Counties, Texas. Center for Archaeological Research. The University of Texas at San Antonio, Archaeological Survey Report 18.

Gagliano, S. M.

1963 A Survey of Preceramic Occupations in Portions of South Louisiana and South Mississippi. Florida Anthropologist 16(4):105-132.

Gagliano, S. M. and J. L. Gregory

1964 A Preliminary Survey of Paleo-Indian Points from Louisiana. Louisiana Studies 4(1):62-77.

Gibson, J. L. and L. J. Miller

1973 The Trappey Mastodon. University of Southwestern Louisiana, Lafayette. Hester, T. R.

1970 A Folsom Point from the Lower Texas Coast. Newsletter, Houston Archeological Society 32:5-6.

1971 Archeological Investigations at the La Jita Site, Uvalde County, Texas. Bulletin of the Texas Archeological Society 42:51-148.

1978 Early Human Occupations in South Central and Southwestern Texas: Preliminary Papers on the Baker Cave and St. Mary's Hall Sites. Center for Archaeological Research, The University of Texas at San Antonio. 
Hester, T. R. and T. C. Hi11, Jr.

1971 Notes on Scottsbluff Points from Southern Texas. Southwestern Lore $37(7): 27-32$.

Holliday, V. T. and K. A. Grombacher

n.d. An Assessment of the Archeological and Historical Resources to be Affected by the Proposed Chiltipin Flood Control Project, San Patricio County, Texas. Texas Archeological Survey, Research Report 29.

Krieger, A. D.

1946 Culture Complexes and Chronology in Northern Texas. University of Texas, Austin.

LeBlanc, R. J. and W. D. Hodgson

1959 Origin and Development of the Texas Shoreline. In R. J. Russe11, ed., Second Coastal Geography Conference:57-102. Washington.

Long, R. J.

1977 McFaddin Beach. The Patillo Higgins Series of Natural History and Anthropology 1. Spindletop Museum, Lamar University, Beaumont.

Oetking, P. F.

1959 Geological Highway Map of Texas. Dallas Geological Society.

Patterson, P. E. and M. M. Ford

1974 Oso Creek Flood Control Project Area, Nueces County, Texas: A Report on the Archeological and Historical Resources. Texas Archeological Survey, Research Report 35.

Price, W. A.

1958 Sedimentology and Quaternary Geomorphology of South Texas. Transactions, Gulf Coast Association of Geological Societies VIII $41-75$.

Scurlock, D., W. F. Lynn, and R. T. Ray

1974 An Assessment of the Archeological Resources of Padre Island National Seashore, Texas. Texas Historical Commission, office of the State Archeologist, Special Report 11. 
Sellards, E. H.

1940 Pleistocene Artifacts and Associated Fossils from Bee County, Texas. Bulletin of the Geological Society of America 51:16271658.

1941 Terrace Deposits as an Aid to Age Determination of Early Man. Bulletin of the Geological Society of America 52(4):2007-2008 (abstract).

1952 Early Man in America: A Study in Prehistory. University of Texas Press, Austin.

Solecki, R. S.

1961 Early Man and Changing Sea Levels: Poplar Island, Maryland. American Antiquity 27(2):234-236.

Stanton, W. and T. R. Hester

1968 Paleo-Indian Materials from a Site on Oso Creek, Nueces County, Texas. Newselter, Houston Archeological Society 25:5-8.

Suhm, D. A., A. D. Krieger and E. B. Jelks

1954 An Introductory Handbook of Texas Archeology. Bulletin of the Texas Archeological Society 25.

Suhm, R. W.

1978 Preliminary Investigation of the La Paloma Mammoth Site (Late Pleistocene), Kenedy County, Texas. TAIUS, Journal of Texas A\&I University $X I(1): 13-36$.

Wheat, J. B.

1953 The Addicks Dam Site: An Archeological Survey of the Addicks Dam Basin, Southeast Texas. River Basin Surveys Papers, Bureau of American Ethnology, Bulletin 154:143-252. 
41 HR 206, A MAJOR SITE IN HARRIS COUNTY, TEXAS

L. W. Patterson

Introduction

This report describes a multi-component prehistoric site, 41 HR 206, in Harris County, Texas. Occupations occurred from the Middle Archaic through the Late Prehistoric periods, with the additional possibility of Early Archaic use. It is a large site for this general area in terms of both physical size and number of artifacts. The artifact collection is especially large when considering that it is the result of surface collection only, with soil disturbance due to rainwater erosion. Artifacts summarized in this report were collected until the spring of 1979.

The location is adjacent to an old stream bed in inland Harris County, on fairly flat ground having mixed sand and clay soils. Overall site dimensions are approximately 300 by 500 feet. There is a distinct concentration of Late Prehistoric materials on the southeast side of this site, nearest to a stream bank. Artifacts from other time periods are scattered throughout the site. This is a mixed coniferous and deciduous wooded area, typical of this region.

Site 41 HR 206 is judged to be an a11-purpose hunting and gathering campsite, probably used seasonally by nomadic peoples over a long time period. There is evidence of hunting activity (projectile points), cooking (fired clayballs and a firehearth), lithic tool manufacture (flint debitage) and lithic tool use (retouch and wear patterns on flakes). Few bones have been recovered. There is no evidence of plant food preparation, such as manos and metates, al though these occur at nearby archaeological sites in small numbers. Some of the available animals would have included deer, turtle, bear, wolf, rabbit, squirrel, raccoon and occasionaliy buffalo. There are a number of plant foods available seasonally, but no remains have been preserved.

\section{Occupation Sequence}

Since no precise dating is available here, chronology is estimated based on projectile point types and the presence of ceramics, including comparison with Wheat's (1953) data. Occupation could occur as early as the Early Archaic period of 6000 to 4000 B.C. based on one possible Angostura point (Suhm and Jelks 1962:167). The Middle Archaic period of approximately 4000 to 2000 B.C. is represented by carrollton, Trinity and Williams dart point types. These point types have ground bases and stem edges, and characterize the Midd7e Archaic farther north in the Dallas area (Smith 1969). The Late Archaic is well represented by typical dart point types, such as Gary, Kent, Ellis, yarbrough and Refugio. These point types are known to continue into postceramic time (Wheat 1953).

The next time period found on this site is the Woodland, defined here as the start of pottery to the start of general use of small bifacial arrow points. It is difficult to separate the Late Archaic from the Woodland, except by the 
arbitrary definition of the start of pottery (Shafer 1975; Jennings 1974:213). The Woodland period can be placed at approximately A.D. 100 to 600 , based on chronology given by Aten (1971:Fig. 10) and Aten et al. (1976:Fig. 16). There appears to be little change in lifeway from earlier time during the Woodland period. The Elam point type found here seems to have been added sometime during the Woodland period or shortly before (Suhm and Jelks 1962:185).

There are indications that the Woodland period may not be a very important component of this site. The ratio of potsherds over $15 \mathrm{~mm}$ square to flint flakes over $15 \mathrm{~mm}$ square is 0.03 . This is fairly low compared to other Woodland sites in this area which have an average sherd to flake ratio of 0.2 (Patterson 1976a). The relatively small number of small dart points is a possible indication of low site use in the Late Woodland period. Dart points tend to become smaller in the Late Woodland, compared to similar dart points in the Late Archaic and Early Woodland (ibid.). This trend to smaller dart points appears to be confirmed by excavations at site 41 HR 315 (Patterson 1978).

The Late Prehistoric is represented here by Catahoula (Patterson 1976b), Bonham and Perdiz arrow points. A11 of these points were found at or near the southeast portion of the creek bank edge, away from the main concentration of artifacts. The Perdiz specimen is larger than most examples, and might represent an early arrow point type, transitional from the Gary dart point, as I have previously proposed (Patterson 1973b, 1976a). Wheat (1953:Table 5) shows that a few Perdiz points were present in the Woodland period.

The occupation sequence here appears to represent roughly 6000 to 8000 years. There is no evidence of historic European contact.

\section{Projectile Point Summary}

A summary of projectile points found on this site is shown in Table 1. Points are illustrated in Figures 1 and 2. As mentioned above, Carrollton, Trinity and Williams points have ground bases and stem edges. So do several dart point stem fragments. The lateral edges of the Wells point stem are ground. Blade edges on Yarbrough and Bonham specimens are serrated. The projectile point types on this site are typical of this general area (Patterson 1976a: Table 4). Many sites in Harris County are characterized by having a large variety of projectile point types, due to long time sequences and the far ranging activities of nomadic people.

\section{Ceramics}

A summary of potsherds found is as follows:

\begin{tabular}{lcc} 
& Over $15 \mathrm{~mm} \mathrm{sq.}$ & Under $15 \mathrm{~mm} \mathrm{sq.}$ \\
\cline { 2 - 3 } Goose Creek Plain & 71 & 81 \\
Conway Plain & 6 & 3 \\
Bone Tempered & 0 & $\frac{2}{86}$
\end{tabular}


TABLE 1. PROJECTILE POINT SUMMARY

Type

Number of

Specimens

Angostura (?)

1

Bonham

1

Bulverde

4

Carrollton

Catahoula

Elam

Ellis

Gary

Kent

Lerma-1ike

Pedernales stem

Perdiz, large

Trinity

Refugio

Travis-like

wells

Williams

Yarbrough

Dart point blade fragments

Dart point stem fragments

Expanding

Contracting

7

Rounded

2

Square

7

Miscellaneous

11 


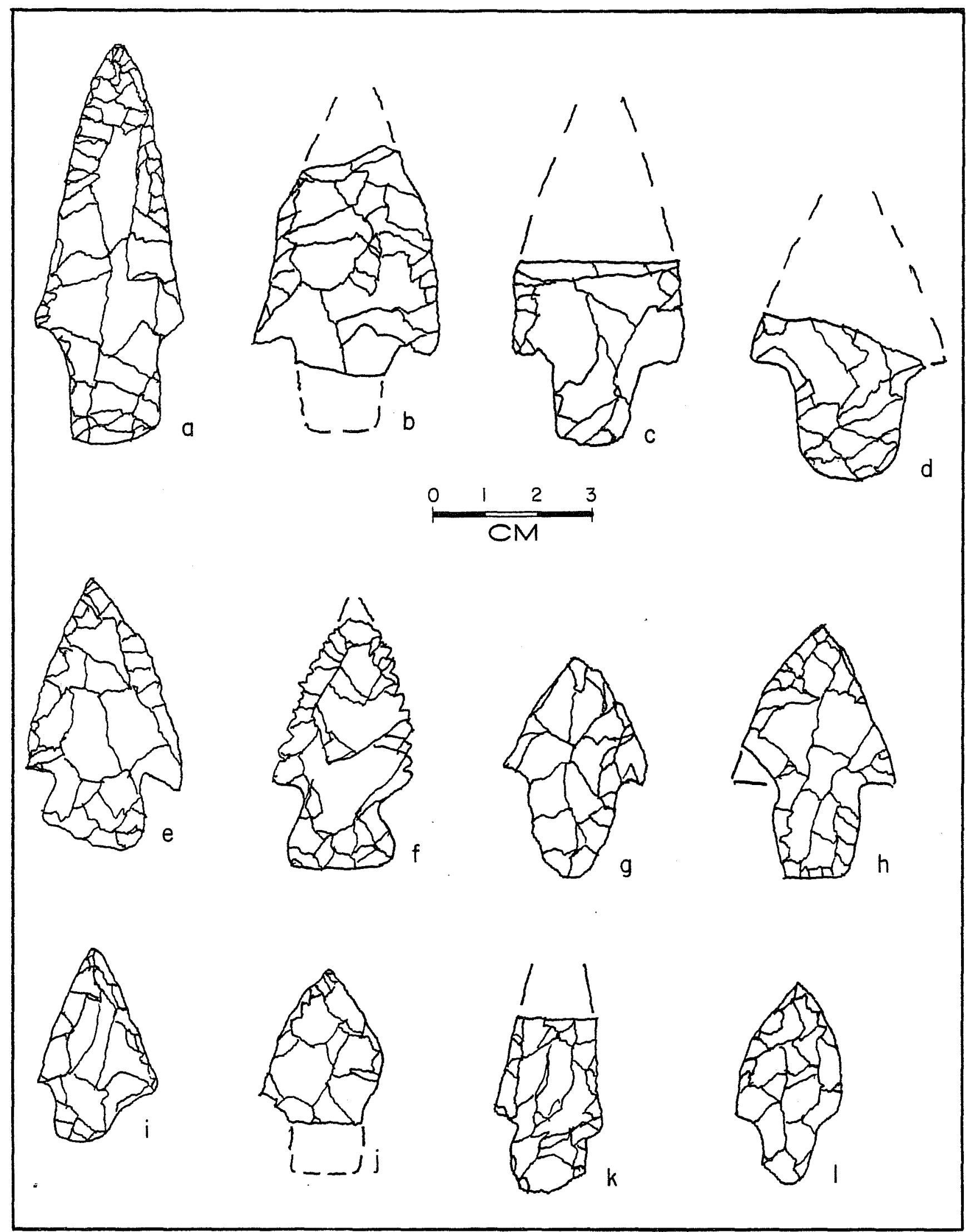

Figure 1. Site 41 HR 206 Projectile Points. a-d, Bulverde; e, Williams; $f$, Yarbrough; $g$, Wells; $h$, carrollton; $i-1$, Kent. 


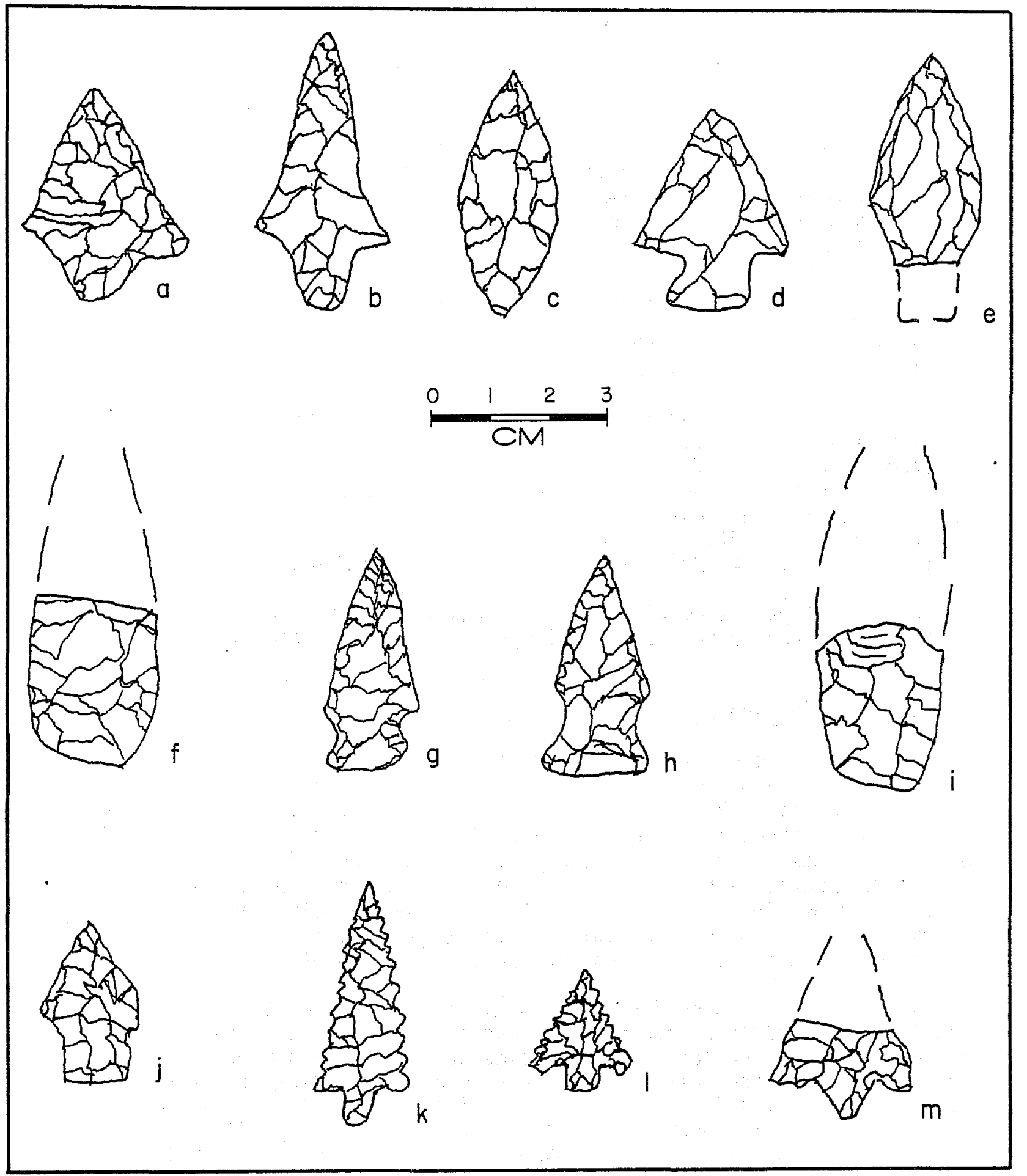

Figure 2. Site 41 HR 206 Projectile Points. a-b, Gary; $c$, Lerma-like; d, Ellis; $e$, Travis-1ike; f, Refugio; g-h, Trinity; $i$, Angostura (?); j, Elam; k, Bonham; 1, Catahoula; m, large Perdiz. 
Inland sites in Harris County do not seem to have the variety of ceramic types found on the coastal margin, such as the Galveston Bay ceramic sequence shown by Aten et al. (1976:Fig. 16). C. N. Bollich (personal communication) is not surprised by this difference between inland and coastal sites. Goose creek is a sandy paste pottery. Conway plain is characterized by an abundance of large sand grains and is placed as one of the earliest ceramic types (ibid.). Bone tempered pottery was identified here by lack of reaction to hydrochloric acid, as compared to shell tempered pottery which does react with acid. Bone tempered pottery has been excavated from the Woodland period in inland Harris County (Patterson 1978), earlier than the Galveston Bay sequence given by Aten et al. (1976:Fig. 16). Sites in inland Harris County do not have much total pottery compared to sites on the coastal margin. Another difference is the lack of sherd tempered pottery on many late inland sites. After having surveyed over 50 inland sites in Harris County, I have yet to find the first sherd with sherd (grog) tempering.

Only two rimsherds and no incised sherds were found. One Goose creek sherd had a neatly drilled hole. Pottery thicknesses ranged from 4 to $9 \mathrm{~mm}$, with an average thickness of $7 \mathrm{~mm}$. Only a small number of sherds were found on the Late Prehistoric portion of this site, which seems to be consistent with my previous conclusion (Patterson 1976a:175) that use of pottery on inland sites declines somewhat after the Woodland period. This is also supported by formal excavation of site 41 HR 315, located within a few miles.

One flat chert pebble of $30 \mathrm{~mm}$ diameter was found with one side highly polished. This may have been used for smoothing in pottery manufacture.

\section{Prismatic Blade Technology}

Industries for the manufacture of smal1 prismatic blades are definitely represented here. Six microblade core fragments were found, along with 14 blade core facial trim flakes and one blade core edge trim flake. There were a total of 345 small prismatic blades and 35 blade-like flakes recovered. If prismatic blades are added to the collection of irregularly shaped flint flakes over $15 \mathrm{~mm}$ square, prismatic blades are $12 \%$ of the flake collection. Blade width distribution is shown in Table 2. This data represents a fairly smooth bell-shaped normal distribution, with a median blade width of $11 \mathrm{~mm}$. This may represent a goal of producing a fairly narrow range of blade widths.

I have previously proposed (Patterson 1973a, 1976a) that the bow and arrow was introduced earlier than normally accepted, concurrent with the arrival of small blade technology. Small blades would have been used to manufacture unifacial points and unifacial hafted side-blades as elements of arrow points, similar to the Eurasian Mesolithic. This technology could be ultimately derived from the far north (Patterson 1973a). There were 24 unifacial points, with varying degrees of retouch found on this site. Most are small and weigh under $1 \mathrm{gram}$, which is an ideal arrow point size. Seventy-two retouched side-blades were found. While these have purposeful retouch, none show wear patterns that would be associated with hafted side-blades used as knives, such as the example illustrated for a prehistoric site in the state of Washington (Kirk and Daugherty 1978:50). There are also 29 examples of snapped blade 
TABLE 2. PRISMATIC BLADE WIDTHS

\begin{tabular}{ccc} 
Width & $\begin{array}{c}\text { Number of } \\
\text { Specimens }\end{array}$ & $\frac{\text { Percent }}{2}$ \\
\hline 5 & 7 & 2.0 \\
6 & 18 & 5.2 \\
7 & 21 & 6.1 \\
8 & 28 & 8.1 \\
9 & 34 & 9.9 \\
10 & 42 & 12.2 \\
11 & 37 & 10.7 \\
12 & 48 & 13.8 \\
13 & 33 & 9.6 \\
14 & 27 & 7.8 \\
15 & 21 & 6.1 \\
16 & 8 & 2.3 \\
17 & 11 & 3.2 \\
18 & 4 & 1.2 \\
19 & 345 & 0 \\
20 & 0 & 1.2 \\
21 & 4 & 0.6 \\
\hline & 27 & 100.0
\end{tabular}


segments that would have been ideal side-blades. While some of these could be due to fortuitous breakage, MacNeish, Nelken-Terner and Johnson (1967:25) recognize this type of artifact, especially when also having some retouch on edges, as perhaps having an Asiatic derivation. Some of the retouch patterns on the unifacial microliths discussed here has been previously described by Patterson and Sol1berger (1974).

\section{General Lithic Technology}

The most common lithic tools on this site are utilized flakes. There are few formal tool types that can be classified relative to the large collection of flint flakes. Shafer (1974) has noted that all-purpose flake tools are the most important elements of lithic collections in east Texas. Formal types of unifacial tools include: 11 flake gravers, 1 graver on a blade, 5 perforators, 2 notched tools, 2 denticulates and 8 end scrapers on smal1 retouched blades (Fig. 3). One possible burin was found, but as I have previously noted (Patterson 1976a:185), burins do not seem to be important in thin flake industries that are typical of Harris County. One large side scraper on a retouched thick cortex flake was found.

Other than projectile points and preforms, only two bifaces were recovered. One is a possible knife or all-purpose tool made from petrified wood. The other is a well-made biface of $\tan$ chert (Fig. 3,a) that may be another preform. It is unusual in that it has a pronounced longitudinal twist.

Flint types used here are typical of those previously described for this area (Patterson 1974). The predominant material is a tan alluvial chert which can be found as close as 25 miles. While most cherts come from nearby alluvial deposits, a few specimens of flint seem to come from the Edwards Plateau. One very good specimen of Georgetown, Texas type flint was found on this site, and this is not unusual for inland Harris County. A detailed discussion of 1ithic procurement patterns in Harris County is being published separately (Patterson n.d.).

Some specific lithic manufacturing techniques are apparent on site 41 HR 206 . Heat treating of flint was widely used over the entire time period represented, as observed by reddish coloration and glossy luster of many specimens. Heat treating is essential for many tough alluvial cherts, as I have observed experimentally (Patterson 1979). Edge grinding of striking platform edges can also be detected. One force application method used was hard percussion. The collection includes 8 whole quartzite hammerstones, ranging from 40 to 150 grams, and 8 quartzite fragments from broken hammerstones.

The collection of irregularly shaped flakes is as follows:

$\begin{array}{lcc} & \text { Number } & \text { Percent } \\ & & \\ \text { Under } 15 \mathrm{~mm} \text { square } & 5103 & 67.4 \\ 15 \text { to } 20 \mathrm{~mm} \text { square } & 1434 & 19.0 \\ 20 \text { to } 25 \mathrm{~mm} \text { square } & 597 & 7.9 \\ 25 \text { to } 30 \mathrm{~mm} \text { square } & 253 & 3.3\end{array}$



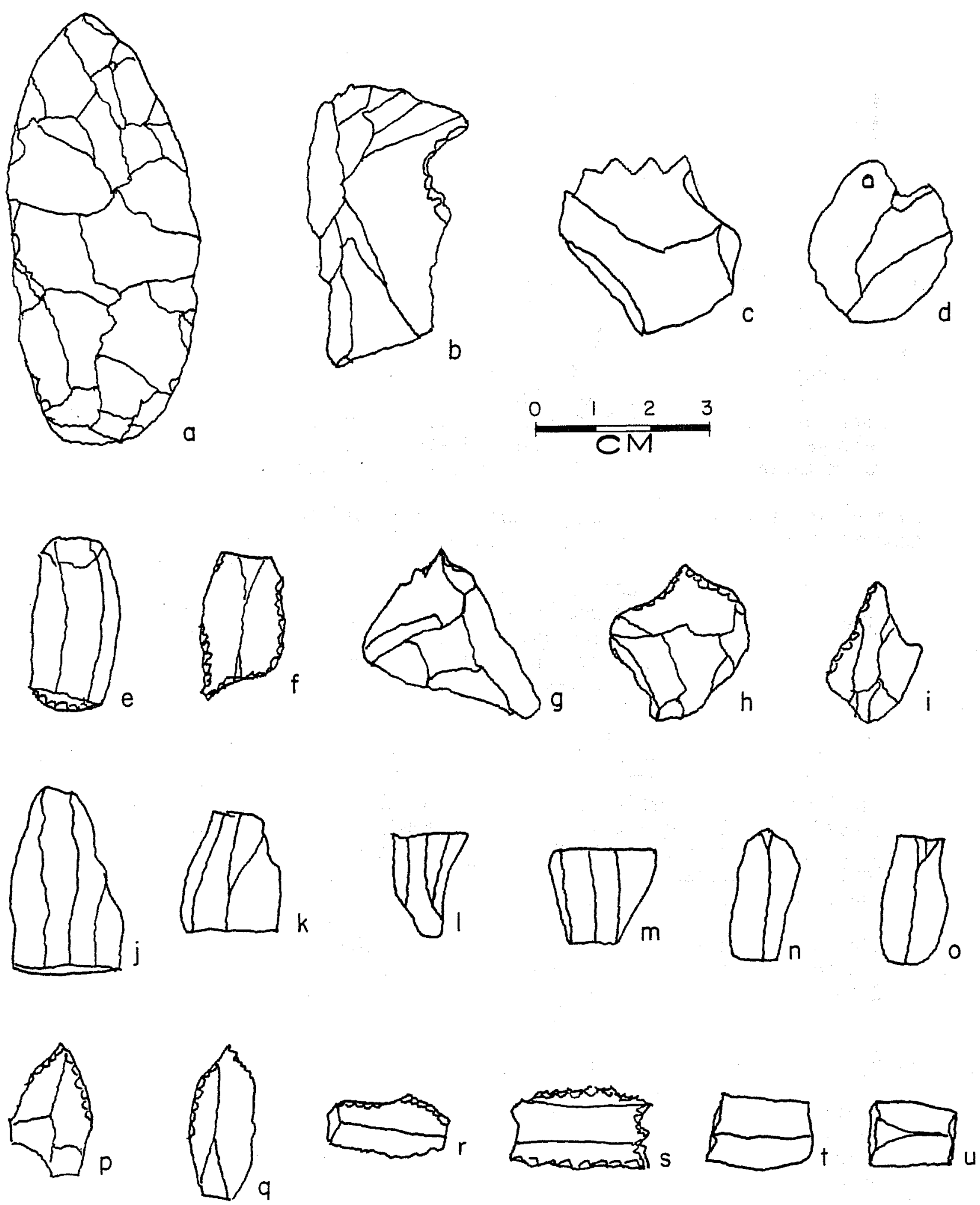

Figure 3. Site 41 HR 206 Artifacts. a, biface; b, notched too 1; c, denticulate; $d$, pendant; e, end scraper on blade; $f$, graver on blade; $g-h$; flake gravers;

$i$, perforator; $j-k$, blade core trim flakes; $1-m$, blade core fragments; $n-0$, prismatic blades; $p-q$, unifacial points; $r-s$, unifacial side blades; $t-u$, snapped blades. 


\begin{tabular}{cc} 
Number & Percent \\
123 & 1.6 \\
36 & 0.5 \\
19 & 0.3 \\
1 & $\quad 0$ \\
\hline 7566 & 100.0
\end{tabular}

This flake size distribution is skewed toward a larger number of smal1 flakes, and is characteristic of systematic bifacial reduction (Patterson and Sollberger 1978). Few flakes above $20 \mathrm{~mm}$ square come from the Late Prehistoric portion of this site, as would be expected by other work in this area (Patterson 1976a, 1978). A random batch of 645 irregular flakes had $11 \%$ primary cortex flakes, $36 \%$ secondary flakes and $53 \%$ internal flakes with no remaining cortex. This is a high enough proportion of flakes with remaining cortex to propose that a significant amount of the lithic collection was made from primary raw materials or only partially trimmed materials. Flake sizes here may indicate limitations in raw material sizes or preferred sizes for transport from lithic sources.

In addition to a large number of very small flint flakes, there is the following general evidence of lithic manufacturing activity:

$\begin{array}{lr}\text { Miscellaneous flint cores } & 19 \\ \text { Petrified wood pieces } & 3 \\ \text { Split pebbles and cobbles } & 14 \\ \text { Miscellaneous thick flint pieces } & 22 \\ \text { Sandstone abrading stones } & 2\end{array}$

It is difficult to demonstrate specific functional uses of stone tools. Utilized flakes at this site have wear patterns typical of experimental patterns for cutting and scraping (Tringham et al. 1974). This perhaps indicates butchering, hide preparation and woodworking activities. Denticulates and notched tools were perhaps used for notching and miscellaneous sawing of wood. Contrary to popular opinion, experiments by J. B. Sollberger (personal communication) and the author indicate that notched tools do not make good "spokeshaves, "but do serve well for sawing functions.

Lithic industries in Harris County typically produce fairly thin flakes. While some thick flakes and chips are found, the majority of flakes have thicknesses of 2 to $6 \mathrm{~mm}$.

Firehearth and Fired Clayballs

The only archaeological feature on this site is a firehearth weathering out of the stream bank. It is farther west than the Late Prehistoric concentration area, and a Refugio dart point was found nearby. This firehearth has burnt clay lumps, burnt wood and land turtle she11. 
As with many sites in this area with Archaic and Woodland components, several fired clay and caliche balls have been found on this site. There are 113 clay balls and 11 caliche balls with an approximate range of diameters from 15 to $55 \mathrm{~mm}$. Clay balls, with possible use for cooking, have been reported in this region by Ambler (1967), Shafer (1968:74), Aten (1967:39) and Patterson (1975a). 0'Brien (1974:66) has described the presence of caliche balls. Caliche balls can be distinguished from clay balls by appearance and by contact with strong acids. Caliche evolves gas upon contact with strong acids because of a carbonate chemical composition. There were also 33 heavily burnt rock fragments, ranging in size from 12 to $45 \mathrm{~mm}$ square, that may have been used for cooking, although this material may represent failures in heat treating, or fortuitous exposure to heat.

\section{Non-Utilitarian Items}

Little evidence of non-utilitarian activities can be found on campsites in Harris County. This may be due in part to poor preservation of wood, she11 and bone. This site yielded 94 small smooth stones of 5 to $20 \mathrm{~mm}$ diameters that might have been used in rattles, as in the Kentucky Archaic (Webb 1974, Aten et al. 1976:41). Four sma11 pieces of red ochre (bright red iron oxide) may have been used as pigments. One flint flake pendant with a single drilled hole was found. The few stone pendants that I have found in Harris County show no great lapidary skill, and the drilled holes are generally where there was already an imperfection in the chert flake. It would not be expected that many non-utilitarian items would be found at campsites such as this, because nomadic people would have difficulty in transport of many possessions.

\section{Conclusions}

Site 41 HR 206 is typical of archaeological sites in inland Harris County which have long occupation periods of several thousand years. Some other sites of this general nature in Harris County include 41 HR 182 (Patterson 1975b), 184 and 315 (Patterson 1978). This is also consistent with Wheat's (1953) previous work, and similar to published sites further inland (Shafer 1968; McClurken 1968). An Archaic hunting and gathering lifeway of a nomadic nature is indicated over the entire time span, although some technological changes did take place here (Patterson 1976a). The Early and Middle Archaic periods remain relatively undefined in Harris County while a large amount of data is now available for later time periods. Future new data will be 1 imited by the continuing destruction of archaeological sites by pothunters and urban development.

Marine oriented sites in this region are generally somewhat different than inland sites. Inland sites are characterized by large lithic collections, small amounts of pottery and not much variety in pottery types. In contrast, marine oriented sites where shellfish use was important have small lithic collections, much pottery and more pottery types. I feel that coastal margin sites may reflect marine oriented subsistence patterns with cultural influences from the east, while inland sites are oriented to the generalized hunting and 
gathering pattern of even farther inland. There is also little data to indicate many important occupations of the coastal margin before the Late Archaic, with the exception of one site published by Duke (1971). It may be that the Late Archaic in this area represents a transitional period leading to more emphasis on seasonal subsistence from marine food sources at littoral sites or more use of the coastal margin by cultural groups from the east. In any event, there was probably some contact between inland and coastal margin Indians, but the specific relations remain largely undefined.

I feel that this report is another demonstration of the value of intensive surface collecting in obtaining detailed data for regional archaeology. When integrated with information on occupation sequences from formal excavations, surface collection allows efficient expansion of the overall data base. 


\section{REFERENCES CITED}

Ambler, J. R.

1967 Three Prehistoric Sites Near Cedar Bayou, Galveston Area. State Building Commission Archeology Program Report 8.

Aten, L. E.

1967 Excavations at the Jameson Site, Liberty Co., Texas. Houston Archeological Society, Report 1.

1971 Archeological Excavations at the Dow-Cleaver Site, Brazoria Co., Texas. Texas Archeological Salvage Project, Technical Bulletin 1.

Aten, L. E., C. K. Chandler, A. B. Wesolowsky and R. M. Malina

1976 Excavations at the Harris County Boys' School Cemetery. Texas Archeological Society, Special Publication 3.

Duke, A. R.

1971 Analysis of Lithic Material from 41 HR 73. Newsletter, Houston Archeological Society 36:3-6.

Jennings, J. D.

1974 Prehistory of North America, Second Edition. McGraw-Hill, New York.

Kirk, R. and R. D. Daugherty

1978 Exploring Washington Archaeology. University of Washington Press, Seattle.

MacNeish, R. S., A. Nelken-Terner and I. W. Johnson

1967 The Prehistory of the Tehuacan Valley: Volume 2, The Non-Ceramic Artifacts. University of Texas Press, Austin.

McClurkan, B.

1968 Livingston Reservoir, 1967-66: Late Archaic and Neo-American Occupations. Papers of the Texas Archeological Salvage Project 12.

O'Brien, M. J.

1974 The Armand Bayou Survey and Excavations. In Frank Hole, ed., Archaeological Investigations Along Armand Bayou, Harris Co., Texas. Houston Archeological Society Report 2. 
Patterson, L. W.

1973a Some Texas Blade Technology. Bulletin of the Texas Archeological Society $44: 89-171$.

1973b A Possible Arrow Point Development Example (41 HR 182). Texas Archeology $17(3): 8-9$.

1974 Harris County Flint Sources. Newsletter, Houston Archeological Society 46:3-4.

1975a A Two Component Site, 41 HR 185. Newsletter, Houston Archeological Society 48:13-14.

1975b Harris County, Texas Site 41 HR 182. Newsletter, Houston Archeological Society 50:6-8.

1976a Technological Changes in Harris County, Texas. Bulletin of the Texas Archeological Society 47:171-188.

1976b The Catahoula Projectile Point: A Distributional Study. Louisiana Archaeology 3:217-223.

1978 Preliminary Report on Site 41 HR 315, Harris Co., Texas. Newsletter, Houston Archeological Society 59:2-4.

1979 Experimental Heat Treating of Flint. La Tierra 6(1):11-13.

n.d. Lithic Procurement Strategies in Harris County, Texas. Submitted to Newsletter, Houston Archeological Society.

Patterson, L. W. and J. B. Sollberger

1974 Lithic Shaping Retouch. Texas Archeology 18(3):13-16.

1978 Replication and Classification of Small Size Lithic Debitage. Plains Anthropologist 23(80):103-112.

Shafer, H. J.

1968 Archeological Investigations in the San Jacinto River Basin, Montgomery Co., Texas. Papers of the Texas Archeological Salvage Project 13.

1974 Archeology and Indians of Southeast Texas. In Participants Handbook, The Big Thicket, Contemporary Service Seminar. University of Houston and Houston Museum of Natural History.

1975 Comments on Woodland Cultures in East Texas. Bulletin of the Texas Archeological Society 46:249-254. 
Smith, C. A.

1969 Archeology of the Upper Trinity Watershed. The Record 26(1):1-14.

Suhm, D. A. and E. G. Jelks

1962 Handbook of Texas Archeology: Type Descriptions. Texas Archeological Society, Special Publication 1.

Tringham, R., G. Cooper, G. Ode11, B. Voytek and A. Whitman

1974 Experimentation in the Formation of Edge Damage: A New Approach. Journal of Field Archaeology 1:171-196.

Webb, W. S.

1974 Indian Knoll. University of Tennessee Press, Knoxville.

Wheat, J.B.

1953 The Addicks Dam Site. Bureau of American Ethnology, Bulletin 154: 143-252. 


\section{A PRELIMINARY STUDY OF THE SHELL ORNAMENTS OF THE \\ TEXAS COAST BETWEEN GALVESTON BAY AND THE NUECES RIVER}

Beverly Janota

Introduction

Along the coast of Texas, between Galveston Bay and the Nueces River, numerous shel1 artifacts have been discovered. These artifacts may be classified into two basic types--ornaments and tools. It will be the purpose of this paper to discuss the various types of ornaments, using examples from private collections, as well as to give some insight into the lives of the people who manufactured and wore them.

Most of the shell ornaments that are presently in collections have been found in burial sites and in middens. Shells that are left exposed on the surface deteriorate quickly, but those that are buried survive longer. Even those that are buried are not always well-preserved. Often all that remains is a chalky substance in the soil. Many times they are so delicate that they crumble into powder after they are exposed to the air (Martin 1930:13). Nevertheless, there are many ornaments that were wel1-preserved and we can study them to learn more about the indigenous people of the Texas coast and areas immediately inland.

Land and Climate

The land along the coast between Galveston Bay and the Nueces River is generally referred to as the Gulf coastal prairie. This area falls within the Texan biotic province described by Blair (1950:100-102). He describes the area as a transitional zone between the forests of East Texas and the grasslands of the western part of the state. The prairies were previously covered with tall grass. Most of the fauna found here also extend into adjacent biotic provinces. Those which are found in the Austroriparian zone to the east tend to be concentrated in the forest regions of the Texan zone, while those which are found in the grasslands to the west tend to be concentrated in the prairie region of the Texan zone. The area has a moist, subhumid climate with rainfall barely in excess of water need.

From Galveston Bay to the Nueces River is approximately two hundred miles. The actual number of miles of coastline is much greater because there are many small bays and numerous offshore islands.

The major rivers which flow into the Gulf between Galveston Bay and the Nueces River are the Brazos, Colorado, Guadalupe and San Antonio. There are also many sma11 tributaries. It is a land of generally flat plains interspersed with forests of oak and hickory. The wooded areas are mainly along the streams which flow through the area (Newcomb 1961:60). This was also true several centuries ago. The diary of an expedition in 1718-19 by Alarcón across Texas describes in detail the forests which were encountered along each river that was crossed. In between were plains of ta11 grass. The forests were evidently much more extensive than they are today (Cêliz 1935:53-72). 
The landscape has been greatly changed by modern man. Forests have been cleared and farmland has been plowed. There has been an invasion of thorny brush, which may have been partially caused by the cessation of aboriginal burning of the savannahs (Hester 1976:3). There has been a decrease in animal populations due to shrinkage of their natural habitat and excessive killing.

Some change in the environment has probably been caused by the weather. Before 1850 the climate was evidently considerably wetter and colder than it is at the present time. Each biotic zone probably had its boundaries slightly farther to the west than they are now. As Texas became hotter and drier, the edges of the biotic zones may have become transitional and moved slightly eastward to their present position. Plants and animals which were adapted to moister, cooler climates either died out or were forced to move farther east to find an environment more to their liking (Janota 1977:9).

\section{The People}

The earliest defined archaeological remains along the central Texas coast are represented by an Archaic complex known as the Aransas Phase. The sites are she 11 middens. There was extensive use of shell for making tools and utensils. It is also distinguished by an absence of pottery. The type site for the Aransas Phase is the Johnson site; others are the Kent-Crane and Live Oak Point sites (Campbe11 1947:63). The dating of these sites is uncertain; but Campbel1 (ibid.: 68) suggests that they occurred before 1500 A.D. because there were no European objects found in the sites at the Aransas levels. Corbin (1974:29) suggests that the sites date from about 2000-3000 B.C. to ca. 1200 A.D. The only good radiocarbon date is for the end of the Archaic, so the earlier dates are only guesses.

Later archaeological remains are represented by an archaeological complex known as the Rockport Phase. The area of the Rockport Phase is along the Texas coast from the Brazos River to Baffin Bay. In most respects, the Rockport Phase is very much like the earlier Aransas Phase (Newcomb 1961:61). The Rockport Phase is almost certainly associated with the Karankawa Indians (Campbel1 1947:71). The Rockport Phase has European materials associated with it. The estimated time span for this phase is from 1700 to 1830 (Campbe11 1958:441).

The indigenous people of the Texas coast at the time of the discovery of the New World were of a group that is generally known as Karankawas. They were not a single tribe, but a series of separate bands which are grouped together because of similar language and cultural attributes (Newcomb 1961:61). The bands were sma11 and were composed of closely-knit groups of kinsmen (ibid.:71).

There were at least five groups of Karankawas. The Capoques and the Hans occupied the area from Galveston Bay to the Brazos River (Newcomb 1961:59). These were the Indians mentioned by Cabeza de Vaca as the first to greet him when he was cast upon the shores of Texas (Bandelier 1973:72-73). The Kohanis lived at the mouth of the Colorado River. The area in and around Matagorda Bay was occupied by the Karankawa proper. On St. Joseph Island and along Copano Bay dwelt the Kopanos (Newcomb 1961:60). 
Cabeza de Vaca described the Indians as a kind people who had compassion for the Spaniards and wept for them upon seeing their misery and distress (Bandelier 1973:59-60). The Indians were horrified that the Spaniards ate some of their own companions who had died. Regarding this, De Vaca said, "The Indians were so startled, and there was such an uproar among them, that I verily believe if they had seen this at the beginning they would have killed them, and we all would have been in great danger" (ibid.:63-64). He mentions that the coastal Indians had greater love for their children than any of the other Indians that he encountered (Bandelier 1973:66).

Others did not have such a benevolent view of the coastal Indians, however. Berlandier (1969:77-78) described them as cannibals and said that "storm-driven or shipwrecked travelers whom chance may lead to these island dwellers are completely at their mercy and many have lost their lives among this inhospitable people (ibid.: 148).

The Karankawa Indians, because of their subsistence pattern, practiced a nomadic lifestyle between the offshore islands and the mainland. They used dugout canoes to get back and forth. They were al so excellent swimmers (Newcomb 1961:67). Cabeza de Vaca gave a good description of the nomadic lifestyle of the Indians. They stayed on the islands from October to February eating fish and roots which they got from under the water (Bandelier 1973:65). From February to the end of Apri1, they went to the mainland and subsisted on oysters. For a month after that, they went to the seashore and Tived on blackberries alone (ibid.:68). For another three months of the year, they went inland and subsisted on "tunas," the fruit of the prickly pear (Bandelier 1973:81).

Hallenbeck (1940:147-149), who traced the route taken by Cabeza de Vaca, believes that the prickly pear thickets were just to the south and southeast of San Antonio, in the present counties of Bexar, Atascosa, Wilson and Karnes. Whether or not the coastal Indians actually came that far inland is doubtful, but shell artifacts have been found as far inland as the San Antonio area. Greer (1977:17) mentions a conch columella ornament found at a San Antonio area site. 01 iva shell beads have been found at site 41 BX 300 recently excavated in northern Bexar County (Paul Katz, personal communication).

It is likely that trade accounted for artifacts being found so far inland. Cabeza de Vaca spent several years as a trader. He gave the following description of his trading between the coast and the interior:
So, trading along with my wares, I penetrated inland as far as I cared to go and along the coast as much as forty or fifty leagues. My stock consisted mainly of pieces of seashells and cockles, and shells with which they cut a fruit which is like a bean, used by them for healing and in their dances and feasts. This is of greatest value among them, besides she11-beads and other objects (Bandelier 1973:74-75).

According to Hester (1972:101), evidence of extensive travel or trade relationships existed between south Texas groups and people of other areas. His observations are based on the presence of exotic specimens of ceramics, obsidian and marine shell from distant places which were found in sites in the interior of Texas. 
Cabeza de Vaca mentioned that the Indians built their houses of mats, which were set up on masses of oyster shel1s (Smith 1966:77). The Indians returned to their favorite campsites year after year, so that in the course of time, great quantities of oyster she11s accumulated. Hallenbeck (1940:128) writes, "I have seen two such beds of decayed shells on the shores of Galveston Bay; one on the 'East Bay' and the other on the 'West Bay' and I am informed that there are other deposits of decayed and partly-decayed oyster-shells about these bays."

Martin (1930:7-8) told of finding heaps of conch shells on the Oso Creek sites. The shells usually had holes broken through one side so that the meat could be removed. Stanton (n.d.:3) mentions that great quantities of conch, oyster and snail shells are still found on many of the sites along Oso Creek, as well as other areas. Obviously, the Indians had great quantities of shells to use in manufacturing their tools and ornaments.

We know how the Indians used the ornaments by studying descriptions that were written by people who actually saw them. Gatschet (1891:125) said that the Karankawa males were more fond of ornaments than were the females who appeared to disdain them. He said that the males wore small shells, glass beads, fruits of the pistachio tree, and 1ittle discs of tin, brass, or other metal on the throat (not the chest). He said that mother-of-pearl was not used for this purpose. This was after contact with the Spaniards, of course. He said that they also wore rings when they were available and that they made bracelets of deerskin.

Berlandier (1969:51-52) says that the coastal people wore necklaces made of she11. He mentions that the use of ornaments in the ears was very widespread, with many individuals having holes pierced all around the edge of the ear in order to attach dangling pendants.

Another way to learn how the Indians used ornaments is to study their burials. In many cases, the bodies were buried wearing ornaments. If the graves have not been disturbed, the skeletons are often found with the ornaments in the positions in which they were worn. Martin (1930:13) describes a burial in which small squares of mother-of-pearl were found around each wrist. Each square had been drilled with two holes. Around the neck and down on the chest were numerous small pendants of the same material, each bored with one hole. Sixty-four of these ornaments were in good enough condition that they could be removed and preserved. Martin's account contradicts Gatschet's statement that the Indians did not use mother-of-pearl. It is possible that after Spanish contact, the Indians began to use other objects in place of shell.

Campbe11 (1957:451-455) describes a number of burials at the Caplen site in Galveston County, Texas. In one burial, there were 46 cylindrical shell beads of conch columella encircling the pelvic region. Another burial had nine large beads of conch columella (three without longitudinal perforation) which lay between the right humerous and the thorax. Other burials had various numbers of shel1 beads (some 1 or 2, others 22 and 32) in the neck region. One burial had 90 small beads on the neck vertebrae and 13 large beads, some undrilled, concentrated in a small area near the center of the chest. 
The She11s

The shells which were used as raw material for the manufacture of ornaments were various types of conches, clams and olive shells. The most common of the conches were the Lightning Whelk, the Fighting Conch, the Pear Whelk, the Horse Conch and the Banded Tulip She11. The clams most commonly used were the Sunray Venus and the Common Jingle Shell. The most common olive shell was the Lettered 0live. A short description of each of the above follows:

Lightning Whelk (Busycon perversum pulleyi). A pyriform (pear-shaped) gastropod with left-handed, or counter-clockwise, aperture. Its color is pale fawn to light yellowish gray, with long axial, wavy brown streaks. Color is usually lost by large adults. The body whorl is large. The spire is turreted and is one-fifth the height of the shell. It is common along the entire Texas coast. Its habitat is intertidal, offshore and in bays (Andrews 1971:114).

Fighting Conch (Strombus alatus). A conical shaped gastropod of dark reddish brown color to a lighter brown with either mottled or with zigzag markings. Its length is three to four inches. Its spire has eight whorls. The body whorl is four-fifths of the total length. It is fairly common along the entire Texas coast. Its habitat is intertidal to about ten fathoms (ibid: : 93-94).

Pear Whelk (Busycon spiratum plagosus). A gastropod, creamy-colored with irregular brown axial lines. It is pyriform in shape (pear-shaped). It is three to four inches in length. The spire whorls are turreted, producing a step at each suture. It is fairly common along the entire Texas coast, living. offshore in sandy bottoms to four fathoms (Andrews 1971:115).

Horse Conch (Pleuropleca gigantea). The largest gastropod that lives in the Gulf of Mexico. Attains a length of two feet. It is easily identifiable because of its size. They range in color from dirty white to chalky salmon. Young ones are bright orange. They are fusiform in shape (spindle-shaped with a long canal and an equally long spire, tapering from the middle toward each end) with about eight convex whorls. It is fairly common along the entire Texas coast in inlet areas and offshore (ibid.:117-118).

Banded Tulip She11 (Fasciolaria hunteria; Fasciolaria lilium). An elongated fusiform univalve. The shell has a cream-colored background with irregular purplish-brown and orange-brown mottlings. There are brown spiral bands which are widely spaced and rarely broken. There are seven to nine rounded whorls. The length is two to four inches. The interior is glazed and white. F. hunteria is fairly common along inlet areas and offshore along the Gulf Coast westward to Mobile Bay. From there west along the Texas coast occurs the species F. lilium (Andrews 1971:117).

Sunray Venus (Macrocallista nimbosa). An elongated, oval bivalve (clam she11) of a pale salmon color with broken, brownish radial lines. They are from four to five inches in length. The exterior is polished with inconspicuous radial and concentric sculptured lines. It is now uncommon along the Texas coast, but must have been more abundant in the past since artifacts made from it are found in Indian middens along the bays (ibid.:207). 
Common Jingle Shell (Anomia simplex). A shiny, translucent bivalve varying in color from pale yellow to dull orange. They are from one to two inches in length. It is subcircular in shape with the upper valve more convex than the flat attached valve. The exterior of the shell is wavy and undulating. The lower valve has a natural perforation. The interior is nacreous. It is common along the entire Texas coast (Andrews 1971:168). They are called Jingle Shel1s because when strung on a necklace, they make a jingling noise as they rub against each other (Jim Markey, personal communication).

Lettered 01 ive (Oliva sayana). An elongated oval gastropod having a polished, cream-colored background with numerous brownish zigzag markings which resemble cuneiform characters or "letters." The interior is purplish in color. It is two to two and one-half inches in length. The shell has five to six whorls and a short spire. It is common along the entire Texas coast, both along the inlets and offshore (ibid.:118).

The Technology

When making ornaments from conch shells, the Indians used either the outer whorl or the columella. Before the outer whorl could be used, it first had to be removed from the rest of the she11. Along the Texas coast, this was usually done by breaking it off in some manner. At the Kent-Crane site, according to Campbel1 (1952:47-48), there is no evidence that the whorl sections were removed by cutting or sawing. They were evidently just broken off in some way. However, in the Brownsvilie area there is evidence of cutting or sawing by making a deep

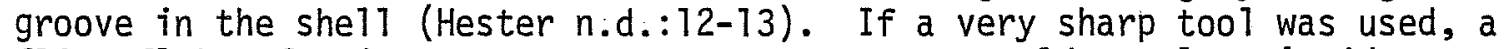
flint flake, for instance, a very narrow groove would result. A wider groove could be produced by abrasion. Along Oso Creek in Nueces County, and at sites in Kleberg County, wedge-shaped pieces of sandstone have been found which could have been used as abraders. The cutting or abrading method of removing the whorl has recently been documented at sites along the central coast of Texas (see Mokry, this volume).

After the whorl was removed, pieces of the desired size and shape were cut from it. This was probably done by using a sharp flint flake or graver to cut a groove in the desired place. When the groove was deep enough, the piece could be snapped along the line. The piece was smoothed along the edges and then perhaps perforated or decorated in some manner.

The columella was removed and used to manufacture ornaments. If the whole columella was to be used, the ends were smoothed off where they had been attached to the rest of the she11. Then other smoothing, perforating or decorating was done. Sometimes only a part of the columella was used. Smal1 cross-sections were cut off, then smoothed and often perforated longitudinaliy to make beads of various types.

Clam shells were used for various types of ornaments. Some were used as beads, simply being strung on a necklace or bracelet. Some, such as the Common Jingle She11, had natural perforations; others had to be perforated by the Indians. Clam shells were also cut into various shapes and sizes and made into gorgets arid other ornaments. 
01 ive she11s were used for at least two types of ornaments. The first type was a bead. The spire was cut off and the remaining shell could be strung on a necklace. The second type is known as a "tinkler." To make these, the posterior half of the shel1, which included the spire, was cut off. The remaining part was smoothed, decorated and often had a coyote canine suspended inside it, like a bell clapper. The small end was perforated and strung on a necklace (Collins, Hester and Weir 1969:141).

Generally, shell was worked by the same methods that were used to work stone. It was hammered, chipped, sawed, perforated, ground, pecked, engraved and polished. The tools used to work the she11 were usually made of stone (Mason 1895:150-151). Since stone was not plentiful in this area, the stone tools were certainly held in high regard and were well taken care of. They were used over and over again; the cutting edges were resharpened when they became du11. Often when a stone tool became too worn to use for its original purpose, it was modified into another type; for instance, a worn projectile point or knife might be modified into a drill.

Shells were also worked with tools made of shell, wood, bone and antler (Spier 1970:58).

Hammering or pounding was usually the first step in preparing a shell for use as an ornament. The hammering was usually done with a "hammerstone" which was a stone small enough to hold in the hand but large enough to be able to break off a section of the she11. The "hammerstone" was used only in the initial stages of the work to prepare a blank for further use. The results of hammering necessarily produced a rough product.

Chipping was done with smaller stone hammers or with pieces of bone or antler (Mason 1895:129). These tools allowed pressure to be directed at a smaller area so that the shape of the blank could be more refined.

Sawing or cutting was also used for this same purpose. The tools for cutting were chise1-1ike, or gravers, which were used to make a deep groove. With much patience, the Indian was able to make the groove deeper and deeper until the she11 was cut through. Sawing was done with pieces of sandstone, which also cut through the she11, but made a wider groove. This process was explained in the previous section. Cutting was used not only to shape the ornament, but also for making large perforations.

Drilling was used to make various types of perforations. The perforations were either utilitarian, usually in order to string the ornaments on some type of cord to be worn around the neck or wrists, or decorative, simply to enhance their aesthetic value.

Drilling could be done by two basic methods--by using a hard drill on the softer she11, or by using a soft drill on the harder shell (Spier 1970:57). In the hard drill method, the drill was made of stone or other very hard material. Sometimes the perforator was made of stone which had been worked so that the working end was somewhat in the shape of an ordinary nail. In order to grip it more easily, a broader handle was left at the butt-end. It was held in the hand and rotated with a twist of the wrist, applying pressure at the same time (Mason 1895: 147). 
Composite drills were also used. These were usually shafts of wood which had a stone or other hard point inserted into the lower end. This drill was used by twirling the shaft between the palms of the hands while applying downward pressure (ibid.).

The above drills were effective, but not efficient. A great deal of time and much patience were necessary. More efficiency was gained by using a bow drill or pump dri11. In a bow dril1, the shaft is steadied by a cap-piece which fits over the top end and is also used to apply downward pressure. The lower end rests on the piece to be drilled. The shaft is rotated by means of a bow string which is wrapped once or twice around it, then attached to a lightweight bow. As the bow is sawed back and forth, the shaft rotates (Spier 1970:47).

The pump drill is a similar arrangement, except that the shaft passes through a crosspiece. The ends of the crosspiece are attached to the top of the shaft by cords. A flywheel is commonly mounted on the shaft which is rotated by hand to wind up the cords. This raises the crosspiece. As the crosspiece is pushed down, the cords unwind and rotate the shaft, which continues turning until the cords are wound in the other direction. The downward pumping is repeated over and over until the drilling is complete (ibid.:48). The pump drill was introduced by the Spanish (Driver 1969:513).

Drilling with a soft drill upon the harder shell is the second basic method. This is done by using a soft drill such as bone, antler or reed, which is rotated between the palms. The actual cutting involved is done by using an abrasive, usually sand, which was plentiful (Spier 1970:58). This method was especially useful for drilling deep holes, such as those made in long, tubular beads.

When drilling shell by any method, the drill usually tapers to a point, and the hole which is made shows a corresponding taper. Because of this, it is possible to tell from which side of an ornament the hole has been drilled. Because the depth of the hole is limited by the shortness of the drill point, it is often necessary to backdrill the hole from the opposite side. This is called biconical drilling. It results in a double taper of the hole, with the widest edges on the outside of the hole and the smallest point in the center where the two holes meet. Occasionally, the two holes are misaligned, which is definite evidence of backdrilling (ibid.:57-58).

Grinding was done to alter the shape of the piece and to smooth rough edges. It was accomplished by much rubbing with smal1 pieces of sandstone. 0ccasionally, the inside rough edges of drilled or cut holes were smoothed by grinding. Grinding is a very slow process, requiring hours, days, or even weeks of work, depending on the degree of finish desired (Spier 1970:56-57).

Pecking and engraving were techniques which were mainly used for decoration. Pecking involves indirect percussion, using a flint flake or antler tip which is hit with a larger stone so that more precise control may be had. With each blow, a small bit of the shell is abraded away (ibid.:57). Engraving was done with a sharp object, such as a graver of flint or a piece of hard shell. Small lines and striations were scratched on the ornaments, on the front or reverse sides, and also along the edges (Mason 1895:50). 
The final step in making an ornament is to polish it. This smooths out any imperfections and gives it a glossy finish. Polishing is done by rubbing the ornament with fine sand or with some other type of fine powder. This was done by putting the sand in a piece of buckskin and then rubbing the shell with it. Some polishing also came from use, as it rubbed against other objects or against the body of the wearer. The greasy hands of the Indians would give a beautiful lustre to the shells (ibid.:149).

It is possible that asphaltum was used to fill in engraved lines on the ornaments, or to glue the ornaments to other objects, though there is no evidence of asphaltum on any of the ornaments I have studied, nor have I found reference to this use of asphaltum in articles by other people. However, asphaltum is found in small pieces in many coastal sites and was used to fill in engraved lines on pottery and possibly to cement projectile points into their shaft sockets (Campbe11 1958:434).

Corbin (1963:29) tells of finding asphaltum in various sites along Corpus Christi Bay and says:

Asphaltum was probably picked up by prehistoric people in its natural state on the local Gulf shores. Today natural asphaltum can still be collected on the beaches, sometimes in very large quantities. Authorities working with the problem of keeping Padre Island beaches free of asphaltum believe that it floats across the Gulf from tar pits and seeps on the coast of the Yucatan Peninsula. It arrives on the Texas beaches in a soft enough state to have been applied directly to the pottery, or it could have been collected, allowed to harden, and then remelted when later use was necessary.

The Ornaments

Several private collections of shell ornaments from various sites in the Victoria, Texas area were made available for study through the courtesy of William Birmingham. Most of the ornaments are in excellent condition. They are typical of the various types of ornaments that have been found at sites in the coastal area. The collection does not include every type that has been found but the basic types are represented. The ornaments come from four different areas.

The first area is a site west of the Guadalupe River along McDonald Bayou in Victoria County approximately seven miles west of Bloomington. The official site number is unknown. The majority of the site has been bulldozed.

The second area is a site west of the Guadalupe River on Dry Creek in Victoria County south of the city of Victoria. This is a burial site excavated by. E. A. Vogt. The official site number is unknown.

The third area is a series of four sites along a creek to the west of the Guadalupe River in Victoria County approximately ten miles northwest of the city of Victoria. These are designated 41 VT 26, 41 VT 29, 42 VT 31 and 42 VT 34. A11 the sites have been cultivated. 
The fourth area is a series of sites known as the Wedemeier sites. These are five sites located east of the Guadalupe River about five miles southeast of Nursery in Victoria County. The official site numbers are unknown.

A description of each ornament follows, along with comments regarding its possible use. The species designation of each of the shells was done by Jim Markey who has spent many years collecting and studying sea she11s.

\section{CONCH COLLMELLA ORNAMENTS}

There are four long ornaments which were manufactured from the columella of large specimens of conch shel1, probably the Lightning Whelk (Busycon perversum pulleyi). The columel1a was removed from the body of the shell and was smoothed and rounded, though not enough to obliterate its natural twisting character. The ends were smoothed and perforated (Hall n.d.:no page number). Ornaments of this type have been described as beads by Greer (1977:17). However, Hudgeons and Hester (1977:11) are inclined to believe that they formed a breastplate. Ha11 (n.d.:no page number) describes several of these ornaments from site 41 AU 36 in Austin County.

Long pointed pieces of conch columel1a, but without perforations in the ends, have been described by Holmes (1883:213-217) as pins, with the suggestion that they were worn in the hair. Campbel1 (1947:54-55) describes them as awls and suggests that they may have been naturally formed by wave action on the beach. He says:

On a sloping sandy beach today one can see columellae being rolled back and forth by the waves. Inasmuch as one end is heavier than the other, differential wear will eventually form a pointed end. Even if formed in this natural manner, their presence in such numbers in the shell midden indicates that they were transported there by human agency.

Several of these columella sections with no perforations are found in the George C. Martin Coastal Collection at the Witte Museum in San Antonio. They range in length from 31 to $77 \mathrm{~mm}$.

One ornament (Fig. 1,a) is $109 \mathrm{~mm}$ long and has a maximum diameter of $9 \mathrm{~mm}$. It is biconically drilled at both ends. The top hole is drilled at a $45^{\circ}$ angle and the bottom hole at a $90^{\circ}$ angle. The columella was smoothed and the ends flattened before it was drilled. There are pits and scratches from wear and weathering. It was also found at the McDonald Bayou site.

Another ornament (Fig. 1,C) is $78 \mathrm{~mm}$ in length with a maximum diameter of $6.5 \mathrm{~mm}$. It was biconically drilled through both ends through the swirl at $45^{\circ}$. The columella was smoothed and the ends flattened before drilling. The ornament is deeply pitted from weathering and is darkly colored, suggesting mineralization. It was found at the Dry Creek site.

The fourth ornament (Fig. 1,d) is a lower fragment with an incomplete length of $43 \mathrm{~mm}$ and a maximum diameter of $9 \mathrm{~mm}$. The colume1la has been smoothed, 


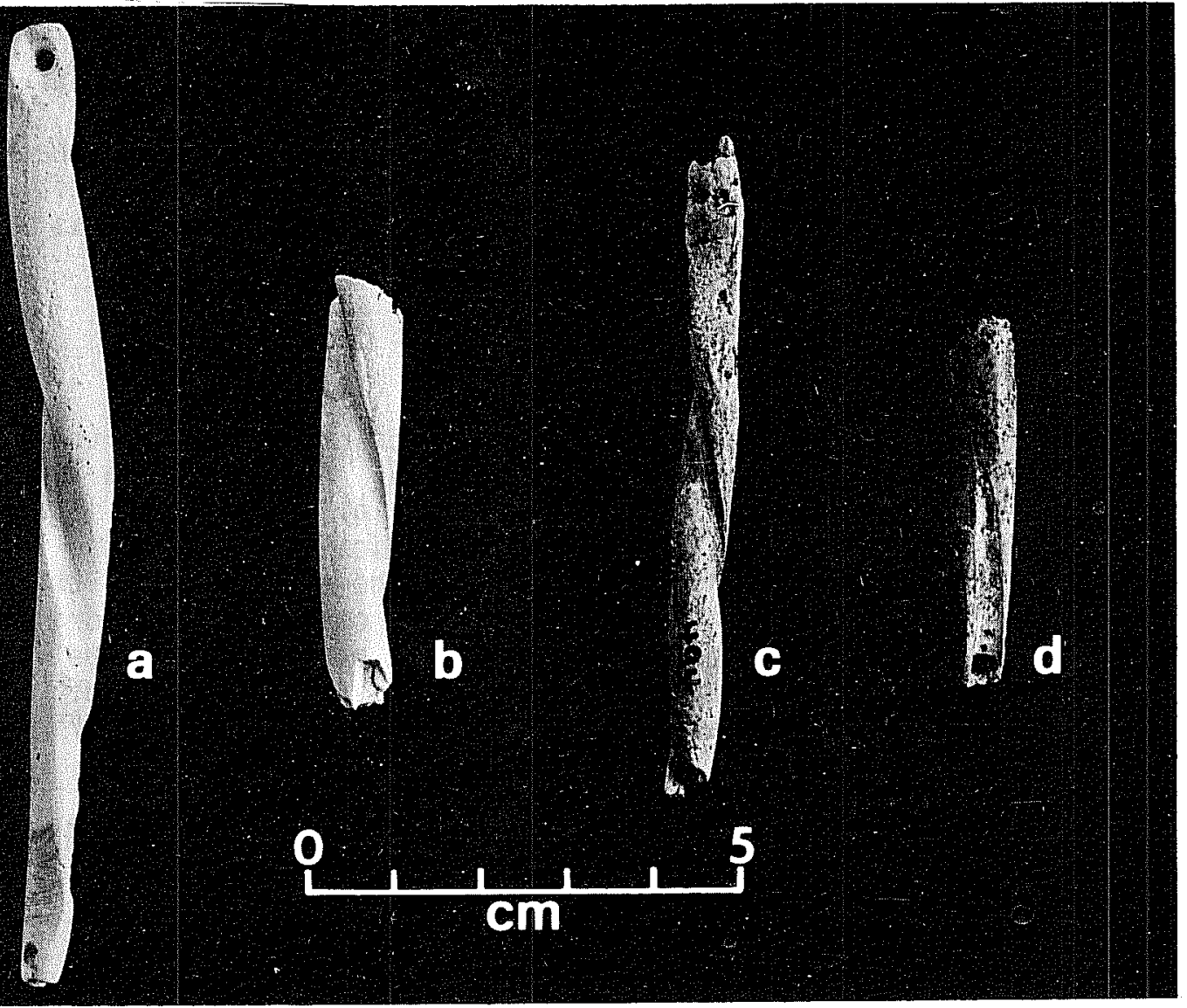

Figure 1. Conch columella ornaments.

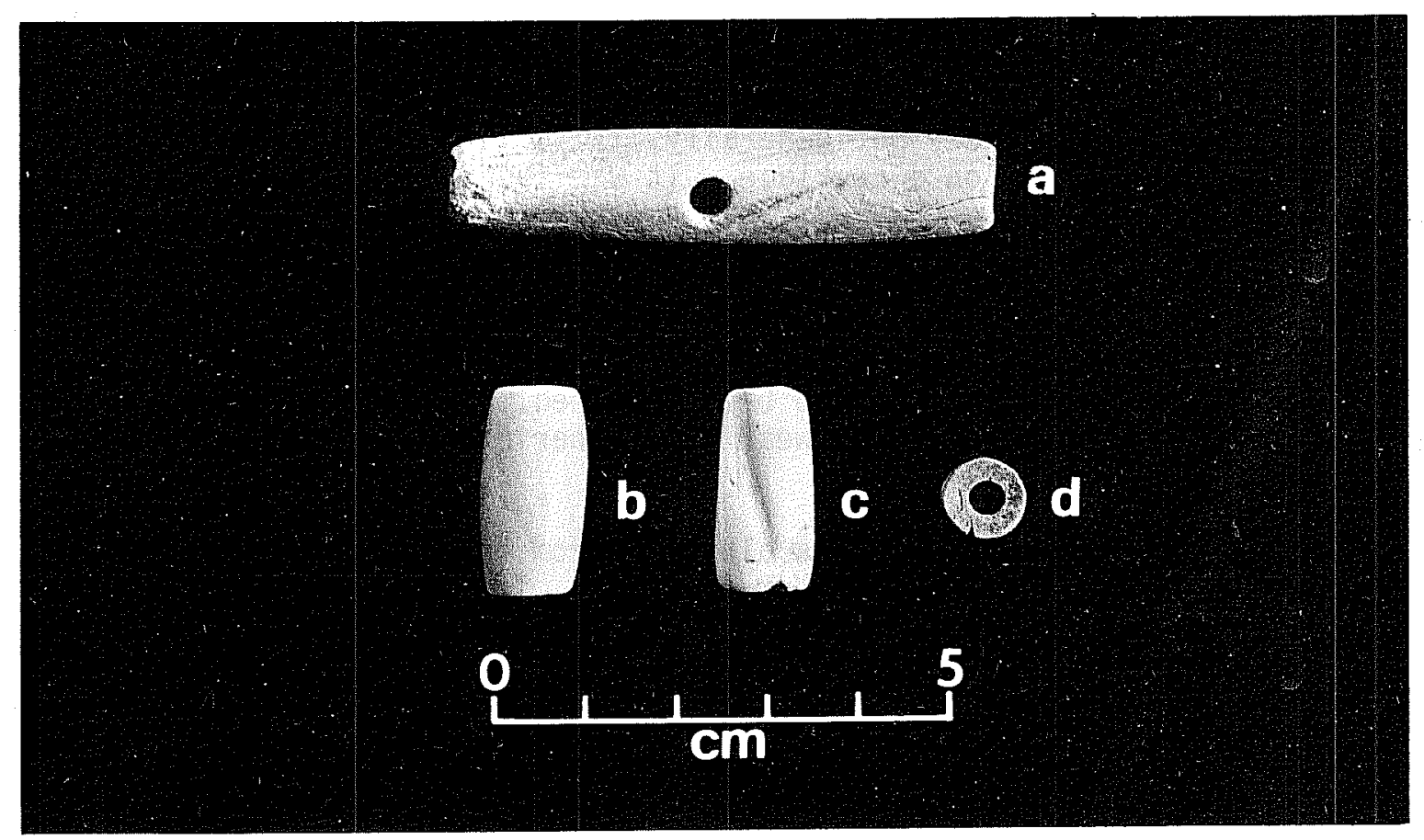

Figure 2. Conch shell Beads. a-c, tubular conch shell beads; d, disc-shaped bead. 
almost obliterating the natural curve near the top of the fragment. A biconical hole has been drilled at $90^{\circ}$ through the swirl at the lower end. It is badly weathered with small pits and scratches covering the surface and has a small crack down one side about $20 \mathrm{~mm}$ long and a larger crack to the left of the one just mentioned, about $30 \mathrm{~mm}$ 1ong and $2 \mathrm{~mm}$ wide. This ornament was found at the Dry Creek site at a depth of 18-24 inches.

\section{TUBULAR CONCH SHELL BEADS}

There are three tubular beads (Fig. 2,a-c) which are made from the columella of the Lightning Whelk (Busycon perversum pulleyi). A specialized type of bead (Fig. 2,a) is cut from a section of the columella. Its length is $60 \mathrm{~mm}$; its maximum diameter is $13 \mathrm{~mm}$. It is drilled biconically through the long axis. During manufacture, one hole was drilled from one end almost to the center of the bead along the long axis (28 $\mathrm{mm}$ deep). The other hole was drilled from the opposite end to beyond the center (39 mm deep), passing under the first hole. A conical hole was drilled perpendicular to, and in the center of, the long axis, to connect the biconical holes drilled from each end (see Fig. 3).

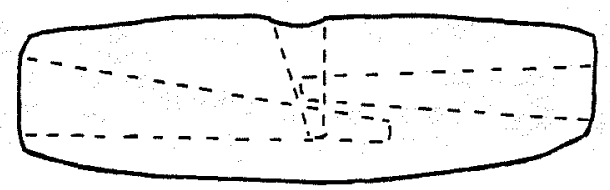

Figure 3. Sketch of Drilling of Tubular Bead.

The columella has been ground down so that very little of the natural groove remains. It has been polished and both ends smoothed. One end has a small piece broken out with a crack about $1 \mathrm{~cm}$ 10ng. The other end shows signs of weathering. There are smal1 scratches showing signs of wear or weathering covering the entire surface, but generally, it is in good condition. This bead was probably strung on a necklace. It was found at one of the Wedemeier sites.

Another tubular bead (Fig. 2,b) was cut from a section of columella. Its length is $23 \mathrm{~mm}$; its maximum diameter is $12 \mathrm{~mm}$. It is drilled from both ends biconically. It has been smoothed so that the natural groove of the columella is obliterated. The ends have also been smoothed. It is in excellent condition with very faint 7 ines from wear or weathering covering its surface. It was found at site 41 VT 26.

The last tubular bead (Fig. 2,C) is also cut from the columella section. It is $22 \mathrm{~mm}$ long with a maximum diameter of $11 \mathrm{~mm}$. It is drilled biconically from both ends. The natural groove of the columella is very obvious, being about $1 \mathrm{~mm}$ deep. One end is badly chipped (an area about $4 \mathrm{~mm} \times 7 \mathrm{~mm} \times 1 \mathrm{~mm}$ deep); otherwise, it is in excellent condition. It was found at site 41 VT 34. 
There are two 0liva Shell ornaments in the collection. One is a bead and the other is a "tinkler" (Fig. 4,a,b). They are both manufactured from the Lettered 01 ive She11 (Oliva sayana).

The bead (Fig. 4,a) is $46 \mathrm{~mm}$ long and has a maximum diameter of $19 \mathrm{~mm}$. It was made by removing the spire tip and smoothing. There are small scratches showing signs of wear or weathering covering the entire shel1. The edge of the outer whorl has a small section broken off, about $9 \mathrm{~mm} \times 1 \mathrm{~mm}$. Other than that, the bead is in good condition. It was found at site 41 VT 37. A similar bead was found at the Live Oak Point site, Aransas County, Texas (Campbel1 1958:429). The 01 iva shell had part of the spire removed, but because of its bad condition, it was impossible to tell if it was actually a bead or not. Campbell thought that it was possible that the spire could have been removed by accidental fracture.

The "tinkler" (Fig. 4,b) is $25 \mathrm{~mm}$ long. Its maximum diameter is $16 \mathrm{~mm}$. It was made by cutting off the posterior half of the shell and smoothing off the cut edge. This formed the bottom edge of the "tinkler." Along this edge were cut a series of 25 notches. Immediately above the notches, a groove was engraved which goes around the shel1. At the anterior end, a conical hole was drilled which gives the "tinkler" a "fishhead" appearance. This type is very rare (Andrews 1971:4). Others of this type have been found in other sites associated with the biconically perforated canine teeth of coyote, which apparently were suspended inside the "tinklers" and functioned as clappers (Collins, Hester and Weir 1969:141). They were strung around the neck to rattle.

The "tinkler" described above was found at site 41 VT 34 . There is a slightly smaller "tinkler" from Nueces County in the George C. Martin Coastal Collection at the Witte Museum in San Antonio.

\section{PENDANTS}

There are five pendants in the collection. Three appear to be made from conch she11. The other two appear to be made from clam she11. They were probably worn on necklaces.

One of the pendants has a rounded, somewhat triangular shape (Fig. 6,a). It is made from the outer whorl of some conch shell, probably the Lightning Whelk (Busycon perversum pulleyi). The edges have been rounded and smoothed. Its maximum diameter is $53 \mathrm{~mm}$. The reverse side is concave with a depth of $6 \mathrm{~mm}$. There are two biconically drilled holes near the top edge. The inside diameter of the hole on the left is $3 \mathrm{~mm}$, and of the hole on the right, $4 \mathrm{~mm}$. The front surface is covered with scratches indicating wear and weathering. The reverse surface is badly weathered, with many sma11 scratches and cracks. There is a darkened area around the larger hole. The edges are severely eroded. This pendant was found at site 41 VT 34. A similar ornament was found at the Caplen site (Campbel1 1957:463). It had four holes drilled near the top edge and a design of small shallow holes which were randomly drilled into the surface. Campbell mentioned that in 1957 this was the only circular gorget of conch 


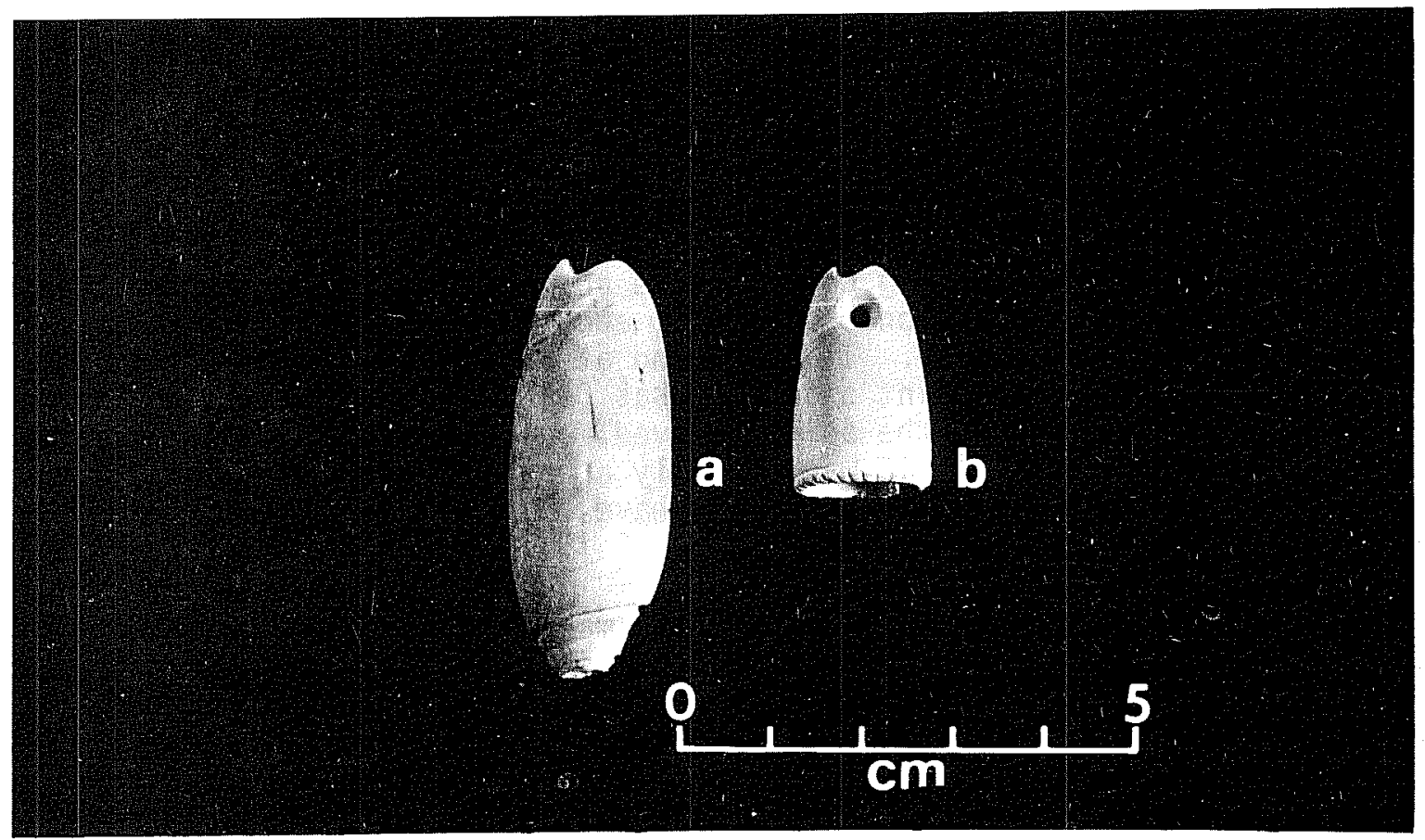

Figure 4. Oliva Shell ornaments. a, bead; b, "tinkler."

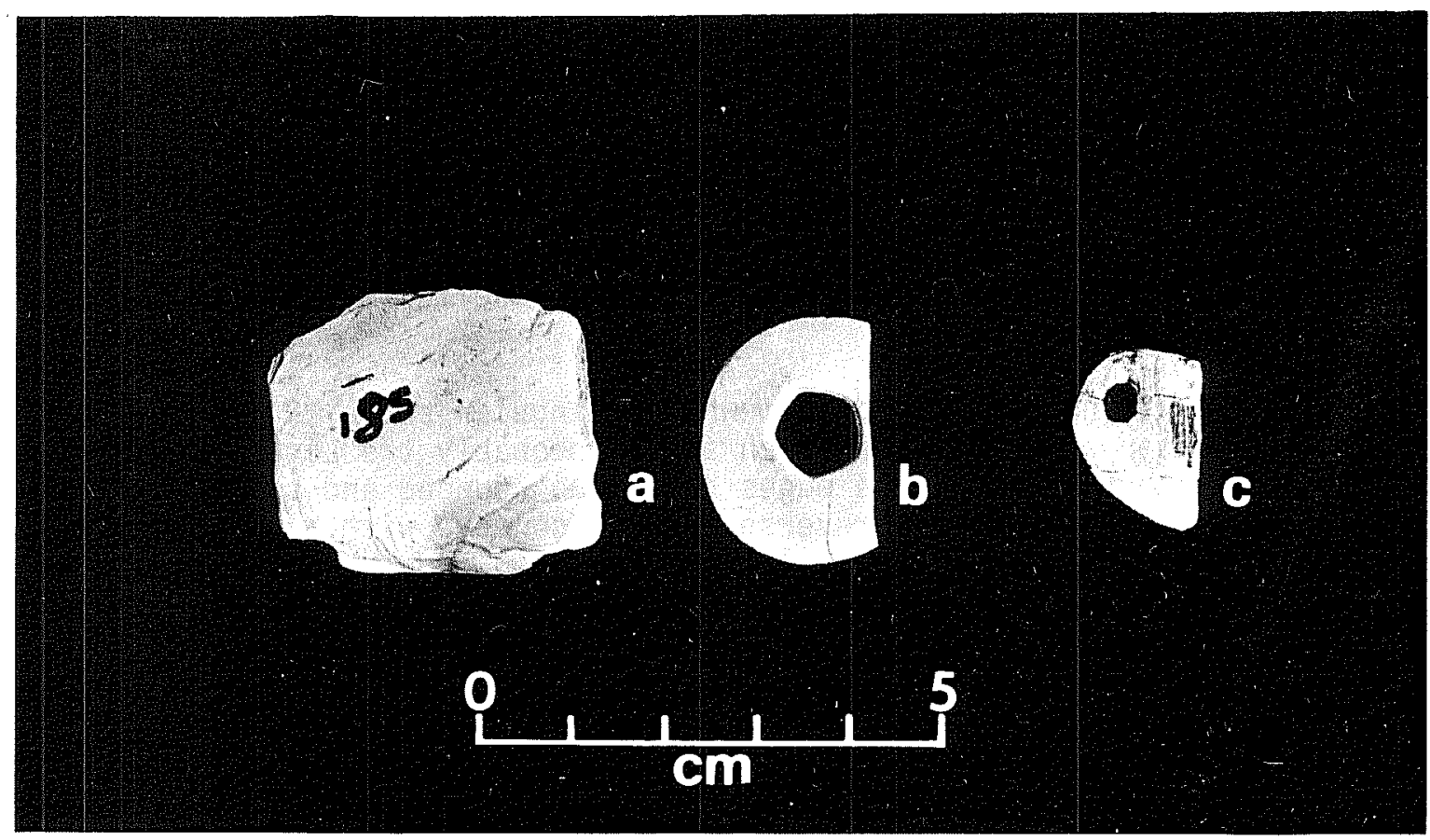

Figure 5. Shell ornaments. a, clam shell pendant; b-c, disc-shaped beads. 
There are two 01 iva Shell ornaments in the collection. One is a bead and the other is a "tinkler" (Fig. 4,a,b). They are both manufactured from the Lettered 01 ive Shel1 (Oeliva sayana).

The bead (Fig. 4,a) is $46 \mathrm{~mm}$ long and has a maximum diameter of $19 \mathrm{~mm}$. It was made by removing the spire tip and smoothing. There are small scratches showing signs of wear or weathering covering the entire shell. The edge of the outer whor 1 has a smal1 section broken off, about $9 \mathrm{~mm} \times 1 \mathrm{~mm}$. Other than that, the bead is in good condition. It was found at site 41 VT 31. A similar bead was found at the Live Oak Point site, Aransas County, Texas (Campbel1 1958:429). The 01 iva she11 had part of the spire removed, but because of its bad condition, it was impossible to tell if it was actual1y a bead or not. Campbel1 thought that it was possible that the spire could have been removed by accidental fracture.

The "tinkler" (Fig. 4,b) is $25 \mathrm{~mm}$ long. Its maximum diameter is $16 \mathrm{~mm}$. It was made by cutting off the posterior half of the shell and smoothing off the cut edge. This formed the bottom edge of the "tinkler." Along this edge were cut a series of 25 notches. Immediately above the notches, a groove was engraved which goes around the she11. At the anterior end, a conical hole was drilled which gives the "tinkler" a "fishhead" appearance. This type is very rare (Andrews 1971:4). Others of this type have been found in other sites associated with the biconically perforated canine teeth of coyote, which apparently were suspended inside the "tinklers" and functioned as clappers (Collins, Hester and Weir 1969:141). They were strung around the neck to rattle.

The "tinkler" described above was found at site 41 VT 34 . There is a slightly smaller "tinkler" from Nueces County in the George C. Martin Coastal Collection at the Witte Museum in San Antonio.

\section{PENDANTS}

There are five pendants in the collection. Three appear to be made from conch she11. The other two appear to be made from clam shell. They were probably worn on necklaces.

One of the pendants has a rounded, somewhat triangular shape (Fig. 6,a). It is made from the outer whor 1 of some conch she11, probably the Lightning Whelk (Busycon perversum pulleyi). The edges have been rounded and smoothed. Its maximum diameter is $53 \mathrm{~mm}$. The reverse side is concave with a depth of $6 \mathrm{~mm}$. There are two biconically drilled holes near the top edge. The inside diameter of the hole on the left is $3 \mathrm{~mm}$, and of the hole on the right, $4 \mathrm{~mm}$. The front surface is covered with scratches indicating wear and weathering. The reverse surface is badly weathered, with many small scratches and cracks. There is a darkened area around the larger hole. The edges are severely eroded. This pendant was found at site 41 VT 34. A similar ornament was found at the Caplen site (Campbel1 1957:463). It had four holes drilled near the top edge and a design of small shallow holes which were randomly drilled into the surface. Campbe11 mentioned that in 1957 this was the only circular gorget of conch 


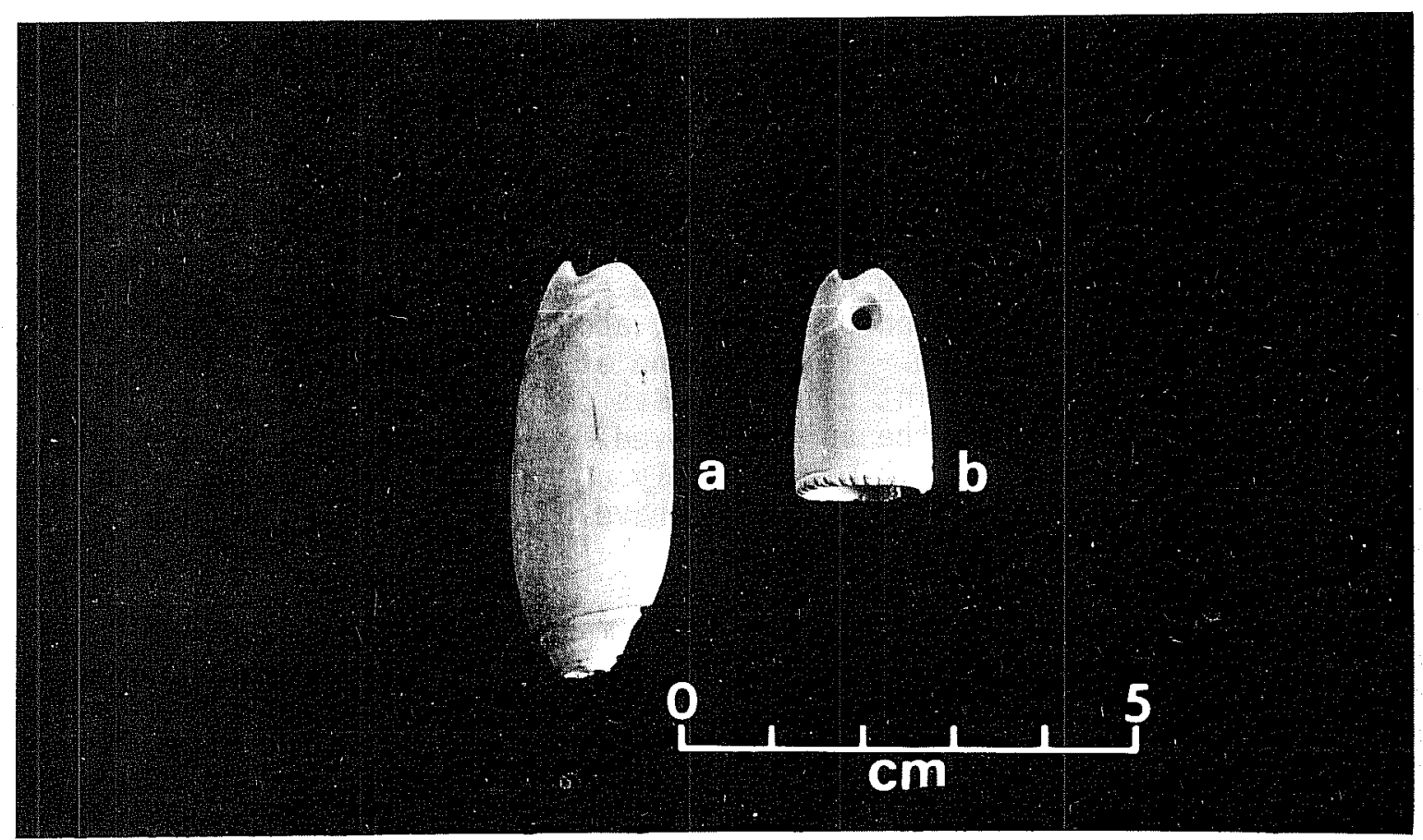

Figure 4. Oliva Shell Ornaments. a, bead; b, "tinkler."

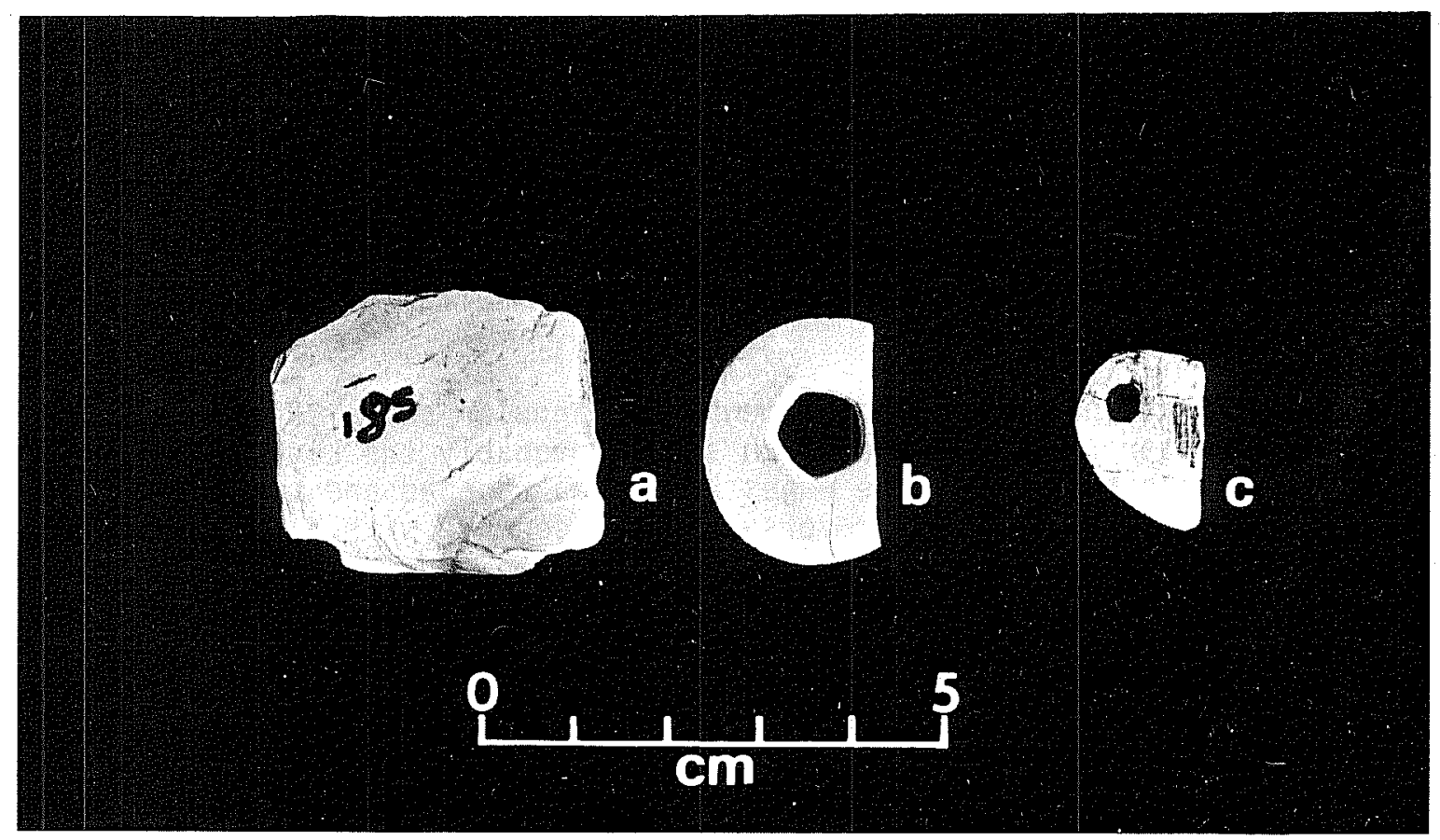

Figure 5. Shell ornaments. a, clam she11 pendant; b-c, disc-shaped beads. 
she11 which had been found on the Texas coast, but that they were widely distributed in the Late Prehistoric cultures of the eastern United States.

One of the pendants is a fragment, about half of it being missing (Fig. $6, b)$. It was probably made from a section of the shell of a Sunray Venus (Callista nimbosa). It apparently was generally round in shape. Its maximum diameter is $49 \mathrm{~mm}$. It is about $3 \mathrm{~mm}$ thick along the broken edge and about $2 \mathrm{~mm}$ thick along the smooth edge. The reverse side is concave with a depth of $3 \mathrm{~mm}$. The outer edge has been smoothed. There is a biconically drilled hole which the broken edge runs through. On the outside edge is a notch which appears to be biconically drilled. There are scratches from wear or weathering on both sides. This pendant was found at one of the Wedemeier sites. Martin (1930:11-13) describes a pendant which had notches cut into its edge for decoration. The pendant was quite thick, two inches long, rounded at the top and straight along the bottom. There were two holes for suspension drilled at the top and four along the bottom edge for decoration. Notches were cut in the spaces between the holes.

A very interesting ornament is shown in Fig. $6, \mathrm{c}$. It is generally round in shape, but it looks as if it could have been hexagonal before it became so worn. One edge has been broken off. The five edges that remain are straight 1ines. It was made from the outer whorl of the Lightning Whelk (Busycon perversum pulleyi). The maximum diameter is $45 \mathrm{~mm}$; it is about $5 \mathrm{~mm}$ thick. The reverse side is concave with a depth of $4 \mathrm{~mm}$. There is a biconical hole drilled in the center at an angle of approximately $45^{\circ}$. Because there is only one hole, it is possible that this ornament could be classified as a bead rather than a pendant. The whole shell is covered with scratch marks. It is badly weathered. The reverse side has a series of shallow holes drilled to form a design in the shape of an "X" crossing the center hole. This ornament was found at one of the Wedemeier sites.

There is a rectangular-shaped pendant that is in very good condition (Fig. $6, d$ ). It was made from the outer whorl of a conch she11, probably the Lightning whelk (Busycon perversum pulleyi). The edges are rounded and smoothed. The corners of the rectangle are rounded. It averages $2 \mathrm{~mm}$ in thickness. It is $53 \mathrm{~mm}$ in length and $41 \mathrm{~mm}$ in width across the center. The top edge is slightly smaller. The bottom edge is slightly larger. The reverse side is concave with a depth of $4 \mathrm{~mm}$. There are two holes drilled biconically at approximately the center, though nearer the top. The holes were drilled deeper on the reverse than on the front. There is no other decoration. There are scratch marks from wear or weathering covering both surfaces. The pendant was found at one of the Wedemejer sites.

There is a much thinner pendant (Fig. 5,a) in the collection which apparently once was almost square (the pendant is upside down in this photograph). It is made from a clam she11, possibly the Sunray Venus (Macrocallista nimbosa) It is approximately $33 \mathrm{~mm} \times 33 \mathrm{~mm}$ and is about $7.5 \mathrm{~mm}$ thick. The edges are bad7y worn and the corners have been broken off. There were two holes in the upper corners which were conically drilled from the reverse side. The reverse side is curved from top to bottom with a depth of $6 \mathrm{~mm}$. The entire ornament is badly weathered. It was found at the Dry Creek site at a depth of 0-6 inches. It seems to be similar to square ornaments that are described by Martin (1930:13), 


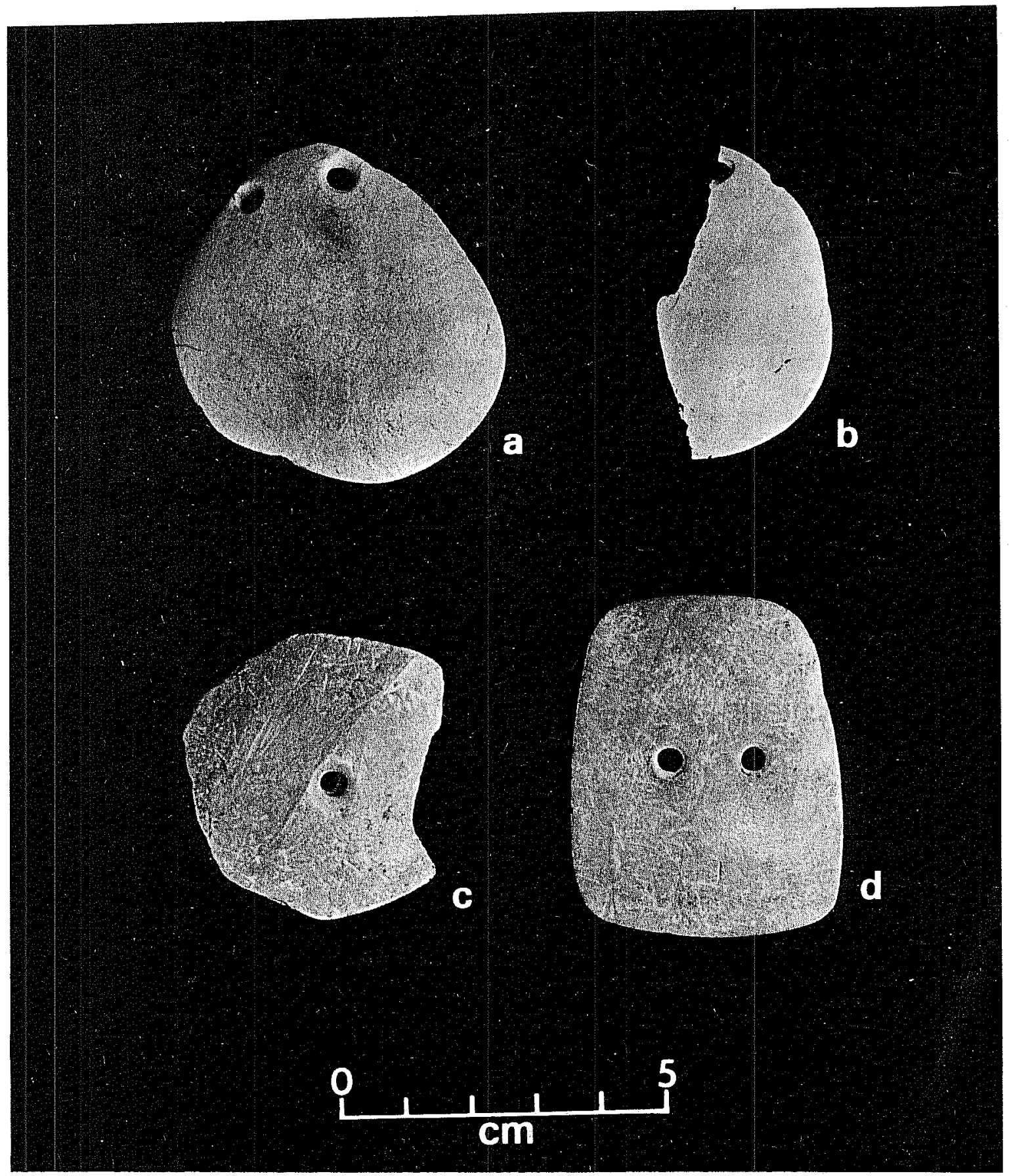

Figure 6. Shell Pendants. a, conch shell pendant; $b$, clam shell pendant; $c-d$, conch shell pendants. 
which were found at a burial site along the Oso Creek. These were square pieces of mother-of-pearl, each drilled with two holes. A number of them were found around each wrist of a skeleton.

\section{DISC-SHAPED BEADS}

There are three disc-shaped beads. One is made from the columella of a conch she11, probably Busycon perversum pulleyi (Fig. 2,d). This bead is $9 \mathrm{~mm}$ across and $5 \mathrm{~mm}$ thick. It is drilled biconically, the hole being about $3.5 \mathrm{~mm}$ across. The bead is somewhat weathered and of dark color, indicating mineralization. It was found at the Dry Creek site. There are several beads of this type in a collection donated by George C. Martin to the Witte Museum in San Antonio. They were found at sites in Nueces County. Some of them have biconically drilled holes like the one described above. Others have a "flower-shaped" hole made by drilling five small holes together in the center of the bead so that the single hole that results has five scallops.

Another disc-shaped bead is generally round in shape with a pentagon-shaped hole (Fig. 5,b). It is made from some pelecypod (clam) she11, probably the Sunray Venus (Macrocallista nimbosa). It is $26 \mathrm{~mm}$ in diameter. The pentagon-shaped hole has been cut, not drilled, from both sides of the bead. Each side of the pentagon is approximately $6 \mathrm{~mm}$ in length. A cross-section of the hole is shown in Figure 7 .

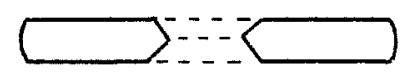

Figure 7. Cross-Section of Hole Through a Disc-Shaped Bead.

The reverse of the bead is slightly concave and has ten small parallel grooves etched into it. About one-third of the bead is missing and appears to have been broken or snapped off. This bead was found at site 41 VT 29.

The third disc-shaped bead is a very fragile, weathered specimen (Fig. 5,c). It is possibly manufactured from the Common Jingle Shell (Anomia simplex) or from the nacreous layers of some other clam. The front of the bead appears to have a small portion of the periostracum remaining, and if this is so, it could be made from a pearl oyster. The bead is generally oval shaped, being about $15 \mathrm{~mm}$ at its widest point. Part of it is missing. It is very flat (1 mm thick). It is conically drilled from the reverse side. The hole is $3 \mathrm{~mm}$ wide. It was found at the Dry Creek site at a depth of 18-24 inches.

Conclusion

The indigenous people of the Texas coast were like people everywhere. They appreciated beauty and enjoyed decorating their own bodies with ornaments of 
various types. They had available to them a raw material of great beauty-the sea shells of the Texas coast. These had such great aesthetic value that they were prized not only by the Coastal Indians but also by the Indians who lived farther inland. They traded their shell ornaments for other things which they needed, such as animal skins, flint and tassels made of deer hair (Bandelier 1973:75).

The Indians had an abundance of patience. The manufacture of she11 ornaments requires a great deal of time. It is obvious that they spent much time in making them, for they not only shaped, smoothed and perforated them, but also enhanced the natural beauty of the shells by decorating them with engraving, notching, etc.

In order to learn more about the ways in which the ornaments were made, some people have tried replication experiments. William Birmingham, of Victoria, Texas, is one person who has undertaken this kind of experimentation in order to better understand the problems involved in ornament manufacture. With more experimentation of this kind, as well as better scientific control of the site excavations, new insight may be gained into the lives and minds of the people who first inhabited the Texas coast.

Special thanks are expressed to William Birmingham, for making the collections of shells available for study, to Jim Markey, for his help in determining the species of the shells, and to Donald Janota, for his assistance with the photography. 


\section{REFERENCES CITED}

Andrews, $J$.

1971 Sea Shells of the Texas Coast. University of Texas Press, Austin.

Bandelier, A. F.

1973 The Journey of Alvar Nuñez Cabeza de Vaca and His Companions from Florida to the Pacific, 1.528-1536. AMS Press, Inc., New York.

Berlandier, J. L.

1969 The Indians of Texas in 1830. Smithsonian Institution Press, Washington, D.C.

Blair, W. F.

1950 The Biotic Provinces of Texas. The Texas Journal of Science 2(1):93-115.

Campbe11, T. N.

1947 The Johnson Site: Type Site of the Aransas Focus of the Texas Coast. Bulletin of the Texas Archeological and Paleontological Society 18.

1952 The Kent-Crane Site: A She11 Midden on the Texas Coast. Bulletin of the Texas Archeological Society 23:39-76.

1957 Archeological Investigations at the Caplen Site, Galveston County, Texas. The Texas Journal of Science 9(4):448-471.

1958 Archeological Remains from the Live Oak Point Site, Aransas County, Texas. The Texas Journal of Science 10(4):423-442.

Céliz, F.

1935 Diary of the Alarcón Expedition into Texas, 1718-1719. The Quivera Society, Los Angeles.

Collins, M. B., T. R. Hester and F. A. Weir

1969 The Floyd Morris Site (41 CF 2), A Prehistoric Cemetery Site in Cameron County, Texas. Part I. Two Prehistoric Cemetery Sites in the Lower Rio Grande Valley of Texas. Bulletin of the Texas Archeological Society 40:119-146. 
Corbin, J. E.

1963 Archeological Materials from the Northern Shore of Corpus Christi Bay, Texas. Bulletin of the Texas Archeological Society 34:5-30.

1974 A Model for Cultural Succession for the Coastal Bend Area of Texas. Bulletin of the Texas Archeological Society 45:29-54.

Driver, H. E.

1969 Indians of North America. University of Chicago Press, Chicago

Gatschet, A. S.

1891 The Karankawa Indians, The Coast People of Texas. Archaeological and Ethnological Papers of the Peabody Museum I(2). Harvard University, Cambridge.

Greer, J.W.

1977 A Columella Bead from the San Antonio Area of South Central Texas. La Tierra 4(2):17-19.

Ha11, G. D.

n.d. Allens Creek: A Study in the Cultural Prehistory of the Lower Brazos River Valley, Texas. Texas Archeological Survey, Research Report 61 (in press).

Ha11enbeck, C.

1940 Alvar Nuñez Cabeza de Vaca. The Journey and Route of the First European to Cross the Continent of North America, 1534-1536.

Kennikat Press, Port Washington, New York/London.

Hester, T. R.

1972 An Artifact of Alibates Dolomite from the Rio Grande Plain. The Texas Journal of Science 14(1):99-101.

1976 Hunters and Gatherers of the Rio Grande Plain and the Lower Coast of Texas. Center for Archaeological Research, The University of Texas at San Antonio.

n.d. A Technological Study of Prehistoric She11 Implements in the Circum-Caribbean and Gulf of Mexico Regions. Unpublished manuscript on file, Center for Archaeological Research, The University of Texas at San Antonio.

Holmes, W. H.

1883 Art in Shell of the Ancient Americans. Second Annual Report of the Bureau of Ethnology to the Secretary of the Smithsonian Institution, 1880-81:185-305. Government Printing Office, Washington, D.C. 
Hudgeons, M. D. and T. R. Hester

1977 An Aboriginal Burial at the Dunn Site, De Witt County, Southern Texas. La Tierra 4(3):10-14.

Janota, B.

1977 Ethnoweather of Texas. Unpublished paper.

Martin, G. C.

1930 Two Sites on the Callo del Oso, Nueces County, Texas. Bulletin of the Texas Archeological and Paleontological Society 2:7-17.

Mason, 0. T.

1895 The Origins of Invention. The M.I.T. Press, Cambridge.

Newcomb, W. W., Jr.

1961 The Indians of Texas. University of Texas Press, Austin and London.

Smith, B.

1966 Relación of Nuñez Cabeza de Vaca. Readex Microprint Corporation, New York.

Spier, R. G.

1970 From the Hand of Man, Primitive and Pre-industrial Technologies. Houghton Mifflin Company, Boston.

Stanton, B.

n.d. A Survey of Karankawa Camp Sites Near Corpus Christi. Corpus Christi Museum Publication 3. 


\author{
NOTES ON CONCH SHELL ADZE \\ TECHNOLOGY, TEXAS COAST \\ E. R. Mokry, Jr.
}

\title{
Introduction
}

Conch she11 adzes made from the body whorl of the conch (Busycon sp.) and the modification process involved in producing such artifacts are discussed.

She 11 artifacts from sites along the northeastern shore of Oso Creek, sites along the False 0so and inland sites are abundant. Specimens made from conch shell include adze-7ike tools, gouges, awls, pendants and, possibly, projectile points.

\section{Description of Conch She11 Adzes}

Specimens surface collected from the sites along Oso Creek have the following characteristics:

1. Two distinct shapes occur - rectangular to roughly square and triangular.

2. Lateral edges are considerably smoothed, slightly ground or unmodified.

3. The steep beveled bit or cutting edge is ground at a right angle to the long axis of the original shell.

4. The cutting edge or bit is ground at either the anterior or posterior end of the she11; in a few specimens a bit or cutting edge is ground on both ends forming a double-edged adze.

5. The cutting edge or bit is ground on the concave face of the shell.

6. The average beveled bit angle is $51^{\circ}$.

The following types of conch shell adzes are described with reference to the previously mentioned characteristics. Table 1 provides a summary of adze attributes.

TYPE I (Figs. 1, a, a! ; 3,c)

Shape. Rectangular to roughly square.

Cutting edge or bit. Ground on the inner face at a right angle to the long axis and toward the anterior end of the original she11. The posterior end retains shoulder knobs.

Lateral edges. Extensively ground to unmodified. 

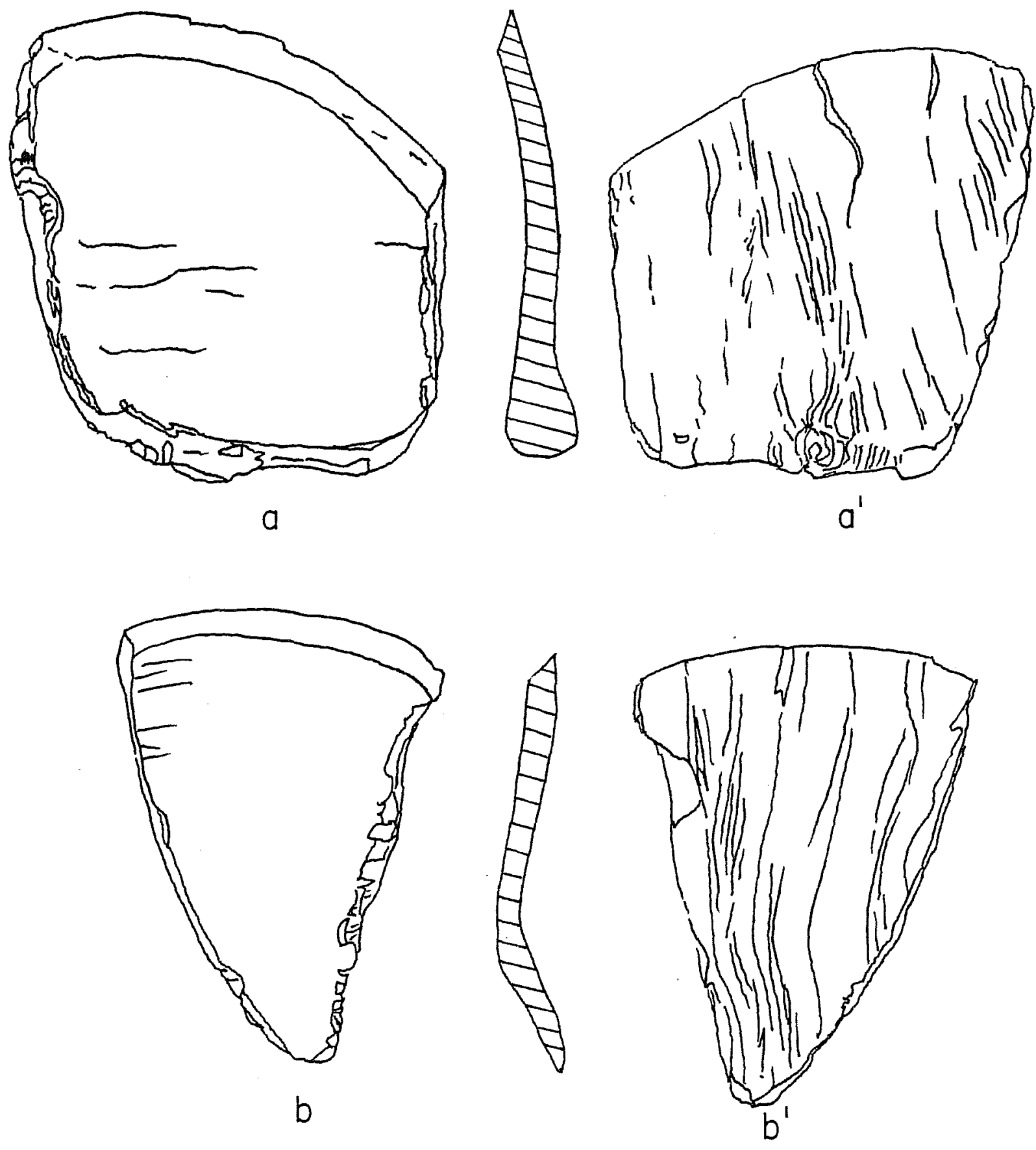

Figure 1. Conch Shell Adzes. a, a', Type 1, rectangular to roughly - square; b, b', Type 2, triangular (drawn to actual size). 
Longitudinal cross-section. Concave.

Provenience. 41 NU 33a, 102, 167, 169.

TYPE II (Figs. 1,b, b'; 3,d)

Shape. Triangular.

Cutting edge or bit. Located toward posterior end or spiral end of original shell, ground on inner face at right angle to long axis of the she11.

Lateral edges. Extensively ground to unmodified.

Longitudinal cross-section. Sinuous.

Provenience. 41 NU 33a, 65, 101, 102, 104, 167, 169.

Method of Manufacture

Once the raw she11 was collected, at least two methods of manufacture or reduction were used to attain a blank for further modification.

METHOD I

The initial modification involved the removal of the extreme outer 1 ip of the body whor1, leaving a uniform thickness in the remaining body whorl. Hammerstones or possibly a large conch shell used as a hammer were used in this reduction. The body whorl was struck along a predetermined 1 ine (along the long axis of the shell and at right angles to the long axis), causing a break or slightly crushed line, making it feasible to remove the desired portion of the body whorl.

Further modification was done by percussion along each edge until the size and shape was attained. The bit or cutting edge was then ground at a right angle to the long axis of the shell and the lateral edges were found to desired smoothness.

Evidence of this method has been observed on both Type I and Type II specimens. METHOD II

The second method of reduction or manufacture involved the use of a thin sandstone blade or abrader. The desired shape and size was extensively cut or ground into the conch body whor (Figs. $2, a, b ; 3, a, b)$. The cutting and sawing continued until the adze blank was completely removed or until it was possible to break away the blank with little or no pressure. The cutting edge was then ground at a right angle to the long axis of the original shell.

Smoothing of the lateral edges was attained during the cutting process. In some cases where the specimen was cut and then removed by breaking, the excess 


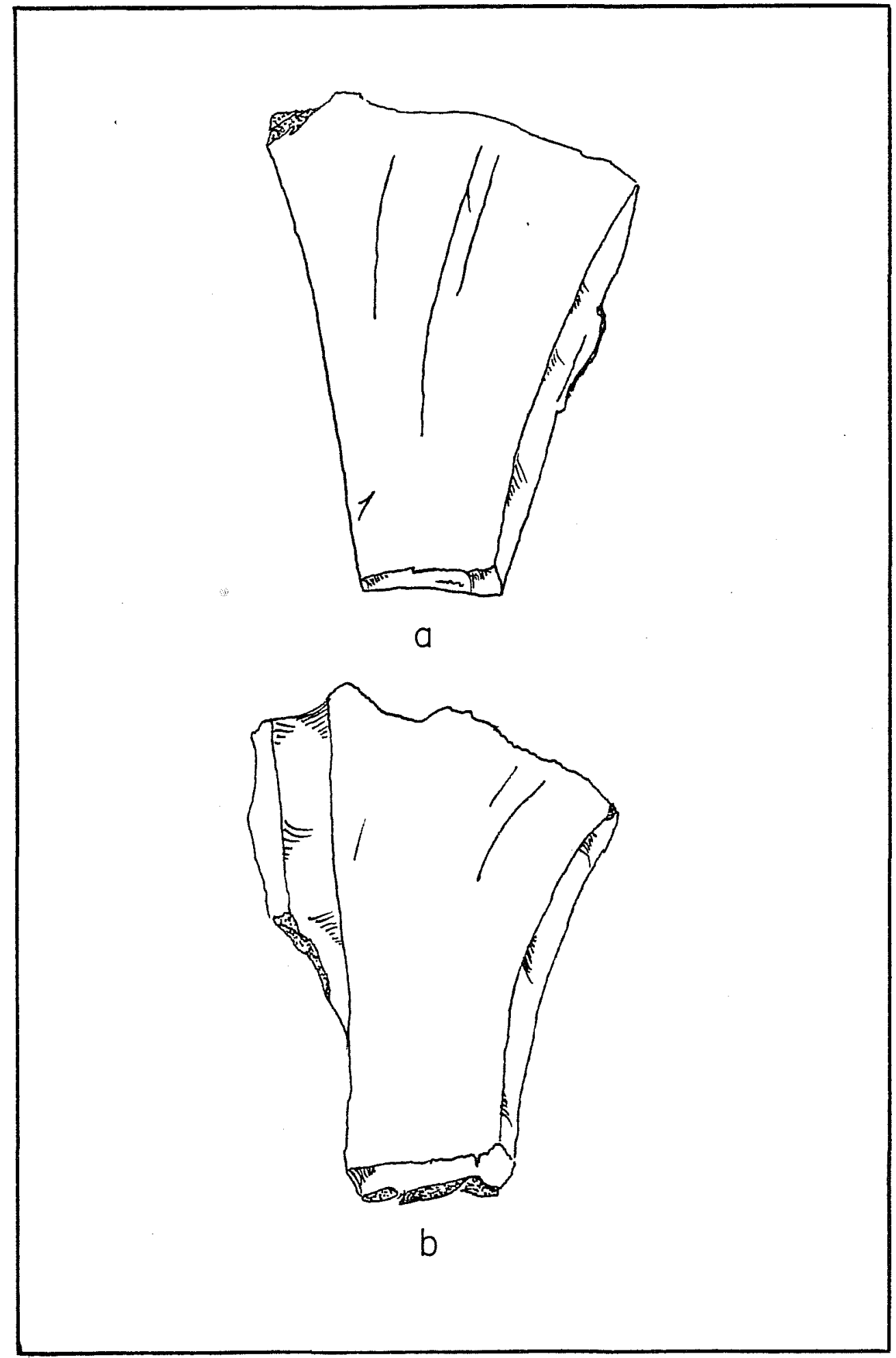

Figure 2. Conch Shell Adze Blanks. a,b, Method II blanks (not drawn to scale; see Fig. 3 for scale). 


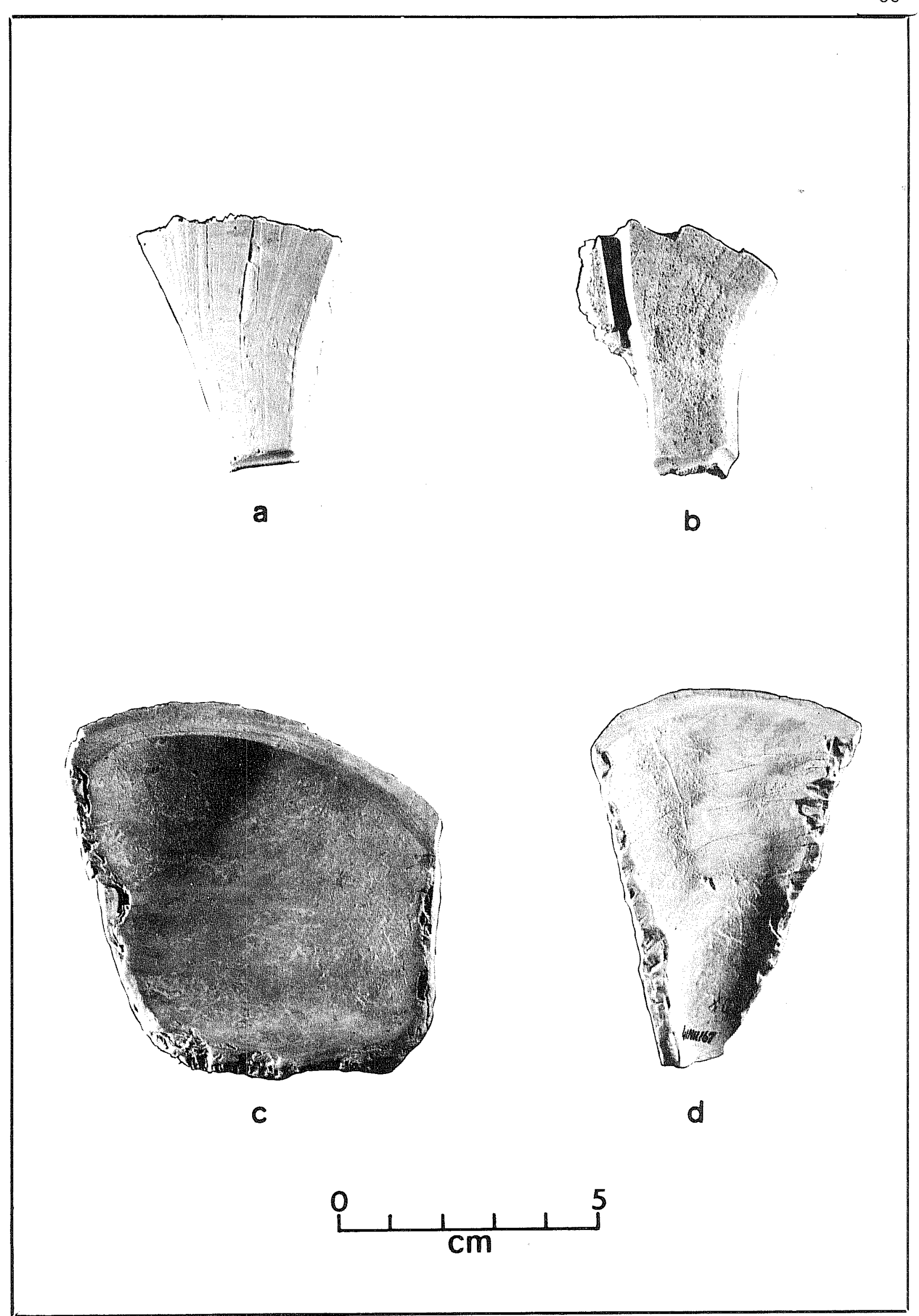

Figure 3. Conch Shell Artifacts. a,b, adze blanks; c,d, finished adzes. 
shel1 and jagged edges were ground down.

This method is evident on specimens of the Type II variety.

Discussion and Conclusion

Undoubtediy, the main reason for the extensive utilization of raw marine shel1 along the middle coast of south Texas was the absence of workable native chert and the abundance of shell along the shores and tidal flats of Padre Island, Corpus Christi Bay and Callo del 0so. The availability of the conch shell provided the coastal inhabitants with a durable and compact material that could be easily worked and extensively used (it could easily be reground to a sharp cutting edge or bit).

Functionally, the shell adze could have undoubtedly been used in wood-working, as a scraper or possibly as a knife. It is assumed that some specimens functioned as hand-held tools (see Fig. $1, a, a^{\prime}$ ). In the small triangular specimens (Fig. 1,b, $b^{\prime}$ ) it is possible that they were hafted to provide better stability in woodworking or skin preparation. No direct evidence of hafting has been observed, and this is only suggestive, but specimens with the triangular outline are in most cases small in proportion to an individual's hand and uncomfortable to work with. Suggested methods of hafting are shown in Figure 4.

Based on excavations at the Johnson and Kent-Crane sites, Campbel1 $(1947,1952)$ included the conch shell adze as a cultural trait of the Archaic period. Sites situated along 0so Creek are characterized by surface scatters of lithic, shell and bone artifacts and various forms of occupational debris. Based on current survey data and time-diagnostic artifacts, these sites can be attributed to both the Late Archaic and Late Prehistoric occupations (single sites with dual components). In general, these sites have been exposed by erosion and, in some instances, by continual farming activities, producing a mixture of both components.

Due to this mixture and lack of documentation of single component sites, a clear separation of the material culture of the Archaic and Late Prehistoric periods remains problematical. However, on virtually all sites, the conch shel1 adze has been documented.

Assuming the shell adze was a cultural trait of the Archaic period along 0so Creek, did it continue to be made into the Late Prehistoric period? The answer to this question remains hypothetical, until further documentation, excavation and a systematic identification of the material culture of each period is made.

In short, this brief analysis provides information on the manufacturing aspects of the conch shell adze and further supplements our knowledge of the shel1 industry along a portion of the middle Texas coast. 
57

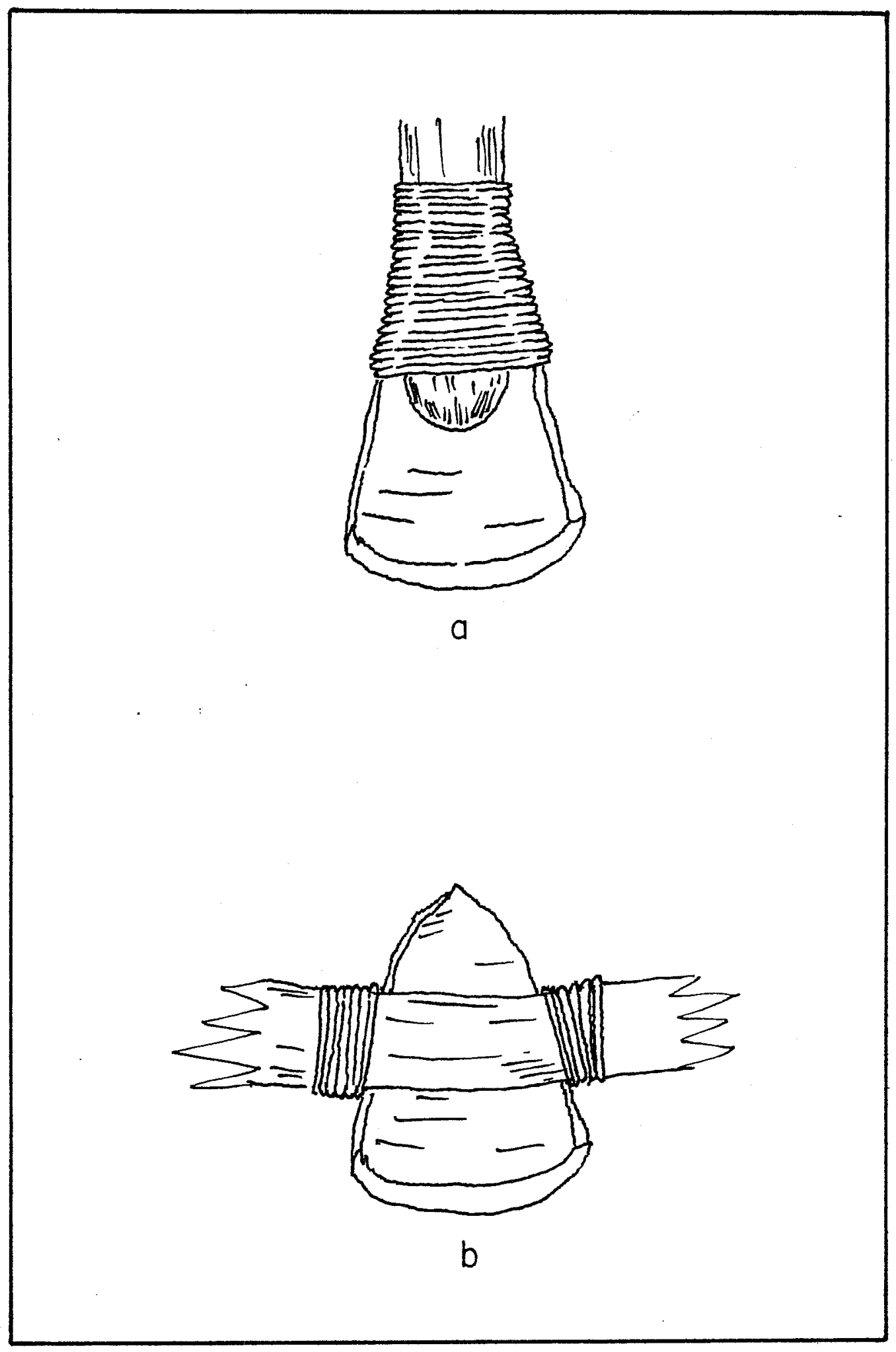

Figure 4. Suggested Methods of Hating Conch Shell Adzes. 
TABLE 1. SUMMARY OF CONCH SHELL ADZE ATTRIBUTES*

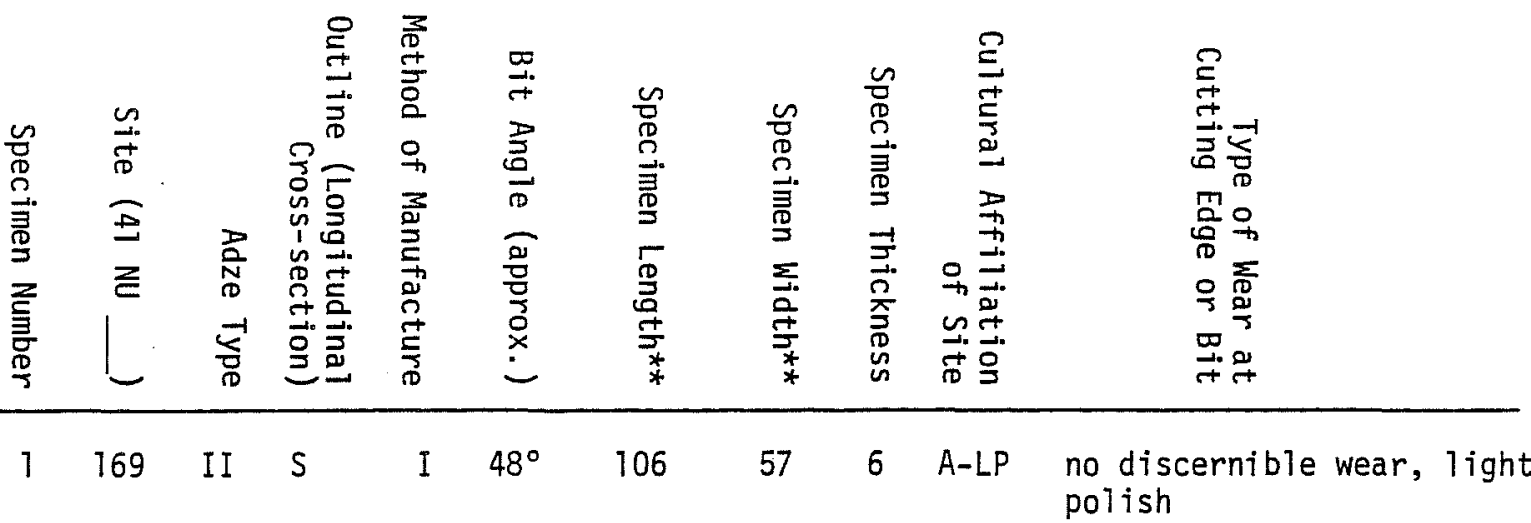

$\begin{array}{lllllllllll}2 & 167 & \text { II } & S & \text { I } & 55^{\circ} & 81 & 50 & 6 & \text { A } & \text { very light polish }\end{array}$

$333 \mathrm{a}$ II $\mathrm{C}$ II $55^{\circ} \quad 52 \quad 42 \quad 5$ LP-A light polish

$\begin{array}{lllllllllll}4 & 169 & \text { II } & S & \text { II } & 50^{\circ} & 95 & 57 & 7 & \text { A-LP " }\end{array}$

$\begin{array}{lllllllllll}5 & 166 & \text { II } & S & \text { I } & 60^{\circ} & 100 & \text { (53) } & 5 & \mathrm{~A} & \text { " }\end{array}$

$6 \quad 102$ II $S$ I $48^{\circ}$ (63) (52) 4 LP-A

$\begin{array}{llllllllll}7 & 104 & \text { II } & S & \text { I/II } & 50^{\circ} & 128 & 65 & 7 & \text { LP-A double bit, dulled, high }\end{array}$

Tustre at extreme bit edge

$\begin{array}{llllllllll}8 & 33 \mathrm{a} & \text { II } & \mathrm{S} & \mathrm{I} & 55^{\circ} & \text { (93) } & 60 & 6 & \text { LP-A }\end{array}$

$\begin{array}{llllllllll}9 & 167 & \text { II } & S & \text { I } & 50^{\circ} & 71 & 51 & 5 & \text { A dulled, light polish }\end{array}$

$\begin{array}{llllllllll}10 & 102 & \text { II } & S & \text { I } & 50^{\circ} & 74 & 54 & 6 & \text { LP-A lightly dulled, light. polish }\end{array}$

11102 I $C$ C $\quad I \quad 40^{\circ} \quad 78 \quad 60 \quad 5 \quad$ LP-A "

$\begin{array}{lllllllllll}12 & 102 & \mathrm{I} & \mathrm{C} & \mathrm{I} & 60^{\circ} & 69 & 68 & 8 & \mathrm{LP}-\mathrm{A} & \text { " }\end{array}$

$\begin{array}{lllllllllll}13 & 102 & \mathrm{I} & \mathrm{C} & \mathrm{I} & 60^{\circ} & 87 & 68 & 6 & \text { LP-A } & \text { " }\end{array}$

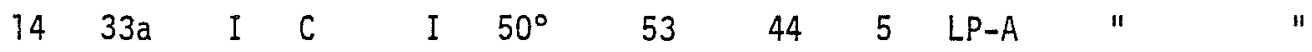

15102 I $C$ I $\quad$ I $45^{\circ} \quad 65 \quad 44 \quad 7$ LP-A dulled, slightly battered, light polish

$\begin{array}{lllllllllll}16 & 167 & \text { I } & C & \text { I } & 50^{\circ} & 60 & \text { (37) } & 3 & \mathrm{~A} & \text { " }\end{array}$

1765 II $S$ I/II $50^{\circ}$ (109) (67) 4 A-LP

$18167-$ C II $50^{\circ}$ (39) (37) 6 A lightly dulled, slightly battered, very light polish at extreme bit edge

19101 II $S \quad$ I $55^{\circ} \quad 60 \quad 38 \quad 5 \quad$ LP iight polish 2065 II $C$ II $55^{\circ}$ (45) $46 \quad 5$ A-LP 1ightly dulled, battered 
SUPPLEMENTARY NOTES FOR TABLE 1.

ADZE TYPE AND OUTLINE

Type I specimens are rectangular to roughly square with a concave (C) crosssection which represents the main portion of the body whorl near the spiral.

Type II specimens are triangular with a sinuous (S) cross-section which represents the portion of the main body whorl with a portion of the siphon body.

METHOD OF MANUFACTURE

See pages 53,56 of text.

BIT ANGLE

The average bit angle for the 20 specimens examined is $51^{\circ}$ (the angle measurements are near-correct to approximate due to the variation of angle planes on any single bit).

\section{THICKNESS}

Due to variable thickness of the body whorl, this measurement was taken at the bit or cutting edge.

\section{CULTURAL AFFILIATION}

A denotes the Archaic period; LP denotes the Late Prehistoric period.

A-LP indicates the greater amount of material culture can be attributed to the Archaic period with the lesser amount of material from Late. Prehistoric occupations.

LP-A indicates the greater amount of material culture is suggestive of the Late Prehistoric period and the lesser amount can be attributed to the Archaic period.

TYPE WEAR AT BIT OR CUTTING EDGE

Most specimens have a light polish at the extreme bit or cutting edge with a slight dulling of this edge and, in some instances, approach a near rounded appearance. Wear will vary due to the slow decomposition of the shell when exposed to weathering and occasionally specimens retain a light sheen from the sand-blasting effect of wind-driven sands. 


\section{REFERENCES CITED}

Campbe11, T. N.

1947 The Johnson Site: Type Site of the Aransas Focus on the Texas Coast. Bulletin of the Texas Archeological and Paleontological Society 18:40-75.

1952 The Kent-Crane Site: A Shell Midden on the Texas Coast. Bulletin of the Texas Archeological and Paleontological Society 23: 39-77. 
ARCHAEOLOGICAL MATERIALS FROM THE ALAZAN BAY

AREA, KLEBERG COUNTY, TEXAS

Lynn Highley

Introduction

This report documents a private collection of artifacts which were surfacecollected from the Alazan Bay area in Kleberg County (see Fig. 1). Chipped stone, she11, bone, ceramic and ground stone artifacts were found at a series of sites in a mile-long section west of Alazan Bay. This region is characterized by clay dunes which rise 10-15 feet above the bay and are cut by deep washes.

Previous information regarding sites and associated artifact assemblages from the Alazan Bay region has been 7 imited. Although the artifacts in this assemblage were surface-collected from several unspecified sites, an analysis is presented to add to the meager amount of information regarding Alazan Bay archaeology.

\section{Archaeological Background}

As noted above, there is a paucity of published archaeological data from the Alazan Bay area. One intriguing discovery was made in 1948, when a serpentine figurine and a bar-type stone gorget were found eroding out of a clay dune near Alazan Bay (Krieger 1953; Hester 1969a:5). T. R. Hester (personal communication) has an extensive set of notes on this discovery, provided to him by W. Armstrong Price of Corpus Christi. The figurine is of Mesoamerican form, related perhaps to the Mezcala style found in the State of Guerrero, Mexico.

A prehistoric site, located in a clay dune, has been briefly mentioned by Hester (1969a:64). This site, 77 C3-2, was reported by W. S. Fitzpatrick as being situated on an embayment on the west side of Alazan Bay, four miles northeast of Cayo Infiernillo. Archaic dart points dominated the collection from the site. Numerous other prehistoric sites have been recorded in the nearby Cayo del Grullo and Baffin Bay vicinities (Fitzpatrick, Fitzpatrick and Campbel1 1964; Hester 1969a, 1971).

Although systematic and extensive archaeological investigations along the central and southern coast of Texas have been 1 imited, several cultural complexes have been devised. The Aransas Complex defines Archaic manifestations occurring along the central Texas coast (Campbe17 1947:41), primarily near Aransas Bay. Marine resources were exploited for food and marine shel1s, particularly conch, served as raw material for projectile points, tools and ornaments (Campbe11 1958:167). The Tithic assemblage includes Abasolo, Ensor, Kent, Lange, Marcos, Matamoros and Tortugas dart points. Chipped stone tools include small flake drills, end scrapers, triangular bifaces, tubular stone pipes, grinding stones and abraders. Bone was utilized to produce tubular beads, pins and flaking tools (Hester 1969a: 6-7). A carbon date of ca. A.D. 1200 is the only date obtained that signals the end of the Archaic period along the central Texas coast (Corbin 1974:34).

The Rockport Complex describes the Late Prehistoric (or Neo-American) period along the central Texas coast. Sites are distinguished by the occurrence of 


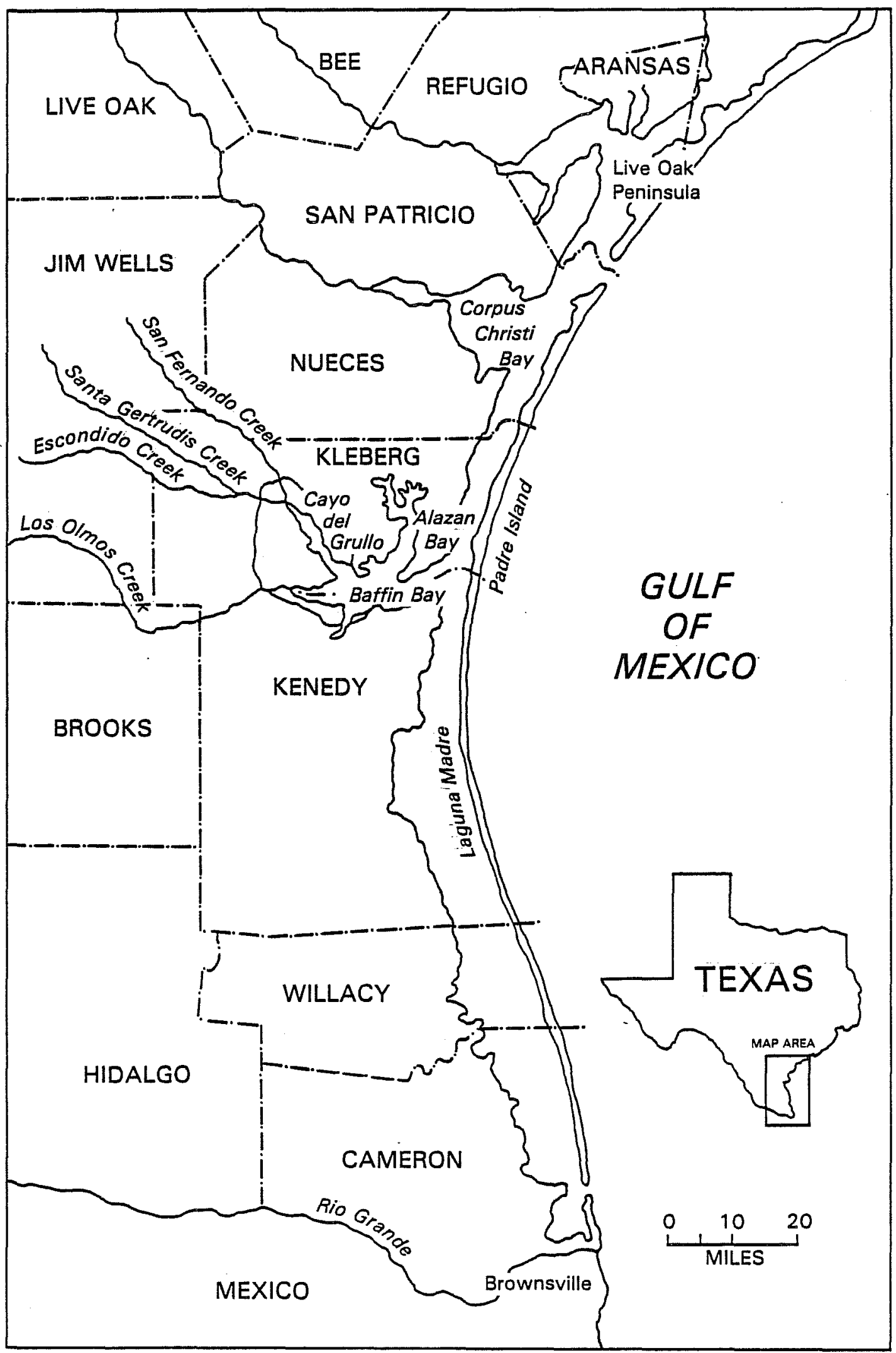

Figure 1. Location of Alazan Bay, Kleberg County, Texas. 
sandy-paste pottery, particularly Rockport Black-on-Gray (Campbel1 1958:168). Perdiz, Scallorn, Cliffton and Fresno arrow points are common; shell arrow points also occur. Matamoros and Catan points continued in use. Chipped stone tools include flake scrapers and snub-nose end scrapers. Conch she 11 pendants and scrapers, bone awls and perforated animal canine teeth also occur (Suhm, Krieger and Jelks 1954:126-127).

Along the southern coast, primarily in the Rio Grande delta region, the Brownsville Complex is used to describe the Late Prehistoric phase. It is characterized by large quantities of marine shell artifacts, particularly ornaments (ibid.:131). Triangular chipped stone arrow points include Starr, Fresno and Cameron. Matamoros and Catan points continue to occur. Small scrapers, bipointed drills, tubular pipes and abraders are common (Hester 1969a:7).

Corbin (1974) has suggested a revision of the Aransas and Rockport Complexes based on the distribution of artifacts along the coast and stylistic changes of these artifacts. Unstemmed projectile points tend to predominate south of Corpus Christi Bay while stemmed varieties predominate north of the Bay (ibid.:34). Corbin speculates that a cultural boundary located just south of Corpus Christi Bay and the Nueces River probably reflects the movements and cultural manifestations of two groups adapted to different ecological surroundings--"one based on subsistence in a mesic climate, and the other existing in a more xeric environment (Corbin 1974:36-37).

Corbin suggests that the Aransas Complex be applied to sites containing projectile point assemblages of Ensor, Catan, Darl-Fairland and Matamoros and delimited to the coastal region between Guadalupe Bay and southern Corpus Christi Bay. The cultural complex preceding the Aransas complex includes Bulverde, Palmillas and Matamoros points, numerous shell tools and incised bone artifacts. It probably extends from the Brazos-Colorado River area to southern Corpus Christi Bay. A separate complex would define the area south of Corpus Christi Bay extending to the Baffin Bay region (ibid.).

Regarding the Rockport Complex, Corbin's studies have added information concerning the spatial and temporal occurrences of arrowpoint types. Perdiz and Fresno appear to be the predominant types and have a wider distribution throughout the area than do other arrow points. Scallorn points precede Perdiz points (Corbin 1974:42).

Artifacts

Chipped stone, she11, bone, ground stone and ceramic artifacts were collected. Measurements are in centimeters and weights are in grams. The following abbreviations are used: L:length, W:width, T:thickness; NW:neck width, SW:stem width, SL:stem length, WT:weight, and D:diameter. Incomplete weights and measurements are in parentheses. 
CHIPPED STONE ARTIFACTS

Arrow Points (21 specimens). A variety of Late Prehistoric arrow points were recovered. Complete specimens or diagnostic fragments are described according to type. Five distal fragments were also recovered.

Cameron (4 specimens; Fig. 2,a). These artifacts have straight bases. One has straight lateral edges, two have convex lateral edges and one has reworked lateral edges which are slightly concave. The reworked specimen is made of black chert and was probably used in drill-1ike fashion. It was found on an island in Alazan Bay. L:1.7-2.2; W:1.1-1.5; T:0.3-0.5; WT:0.71.4.

Lanceolate (1 specimen; Fig. 2,b). This narrow unstemmed specimen has serrated parallel edges that taper to the distal tip. The basal edge is slightly convex; the proximal end has been thinned by the removal of several thin flakes. L:4.0; W:1.2; T:0.6; WT:2.8.

Perdiz (6 specimens; Fig. 2,c). Five of these specimens appear to be finished projectile points while one is probably a preform. They have triangular blades with straight lateral edges. The contracting stem is rounded on two specimens and pointed on two other specimens. The lower stem is broken off of the other two points. Three of the points are bifacial; the other three have unifacial blades and bifacial stems. L:(2.3)-(3.8); W:(1.3)-1.7; $T: 0.2-0.4 ; \mathrm{NW}: 0.4-0.6 ; \mathrm{SL}: 0.6-0.9 ; \mathrm{WT}:(0.5)-(1.7)$.

Starr (2 specimens; Fig. 2,d). These bifacial triangular points have concave lateral edges and a deeply concave base resulting in sharp basal barbs. $L: 1.9-2.8 ; W:(1.5)-(1.6) ; T: 0.2-0.3 ; W T:(0.7)$.

Triangular, Type 1 (5 specimens; not illustrated). These triangular bifaces have straight to slightly concave lateral edges. Bases are slightly concave. They are similar to Starr points, but do not have the same deeply concave basal edge or recurved lateral edges.

Triangular, Type 2 ( 3 specimens; not illustrated). These small triangular artifacts also have concave bases but are not as well made as the Type 1 triangular arrow points. One has straight edges; the other two have broadiy convex 1ateral edges. L:1.8-2.1; W:1.2; T:0.2-0.4; WT:0.8-1.5.

Dart Points (35 specimens). Dart points include several stemmed types as we11 as a variety of triangular specimens.

Angastura (1 specimen; Fig. 2,e). This basal fragment is made of creamcolored chert. One lateral edge has been ground approximately $11 \mathrm{~mm}$ from the base; the other lateral edge has been ground approximately $4 \mathrm{~mm}$ from the base. L:(1.9); W:(1.7); T:0.6; WT:(2.5).

Catan (3 specimens; Fig. 2,f). These triangular points have convex bases and straight or slightly convex lateral edges. One specimen is made of 
silicified wood. One specimen has alternately beveled lateral edges; two specimens are beveled along both lateral edges on both faces. L:2.7-3.8; $W: 2.0-2.5 ; T: 0.5-0.8 ; W T: 3.2-9.8$.

Desmuke ( 7 specimens; Fig. 2,g). These specimens with contracting stems are lozenge-shaped. The lateral edges on five specimens are convex. Two specimens have very straight lateral edges which have been alternately beveled on the left side. One point is made on a patinated flake. $L: 2.7-3.2 ; W: 1.4-1.7 ; T: 0.6-0.7 ; S L: 1.0-1.1 ; W T: 3.0-4.3$.

Ensor (1 specimen; Fig. 2,h). This specimen has a deep side notch on one Tateral edge and a very shallow side notch on the opposite side. Lateral edges are straight, as is the base. $L: 4.4 ; W: 2.6 ; T: 0.8 ; N W: 2.0 ; S W: 2.6$; SL: 1.3; WT:8.3.

Marcos (1 specimen; Fig. 2,i). This basal fragment has deep corner notches which have produced sharp barbs and an expanding stem. The base is straight. $L:(2.8) ; W: 2.9 ; \mathrm{T}: 0.6 ; \mathrm{NW}: 1.5 ; \mathrm{SW}: 2.0 ; \mathrm{SL}: 1.1$; WT:(4.9).

Matamoros ( 8 specimens; Fig. $2, j$ ). These triangular bifaces have straight bases and straight to slightly convex lateral edges. The proximal end has been thinned by the removal of short longitudinal flakes. Five specimens are beveled along both lateral edges on both faces; three specimens have alternately beveled edges. One has reworked lateral edges resulting in concave edges. Both of the lateral edges on this specimen are extensively battered. L:2.6-3.4; W:1.5-2.3; T:0.6-0.7; WT:3.4-6.3.

Tortugas ( 3 specimens; Fig. $2, k$ ). These triangular bifaces have concave bases and slightly convex lateral edges. Longitudinal flakes have been removed to thin the proximal end. Two specimens have alternately beveled lateral edges; one specimen has been beveled along one lateral edge on one face only. L:3.6-4.9; W:1.9-2.3; T:0.5-0.7; WT:4.6-9.4.

Miscellaneous, Type 1 (4 specimens; Fig. 2,1). These four projectile points are very smal1. However, when compared to the small arrow points, they are much thicker and not as well made and are therefore considered to be transitional dart points. These points have shallow side notches and straight lateral edges. One point has alternately beveled blade edges; another exhibits an impact fracture along the distal portion of the point. Two have straight bases; one has a slightly convex base and one has a slightly concave base. L:2.2-2.6; W:1.4-1.6; T:0.6; NW:1.2-1.3; SW: 1.3-(1.5); SL:0.9-1.1; WT:2.0-2.4.

Miscellaneous, Type 2 (1 specimen; Fig. $2, \mathrm{~m}$ ). This shoulderless specimen has a slightly expanding stem with a straight base. The lateral edges are alternately beveled. L:3.8; W:1.8; T:0.6; NW:1.7; SW:1.8; SL:1.0; WT:4.8.

Miscellaneous, Type 3 (1 specimen; Fig. $2, n)$. This specimen has slightly convex lateral edges. Slight shoulders give way to an expanding stem whose edges are ground. The base in concave. L:4.8; W:2.2; T:0.6; NW:14.;

SW: 1.4; SL:1.2; WT:6.1. 
Figure 2. Artifacts from Alazan Bay.
a, Cameron:
b, lanceolate;
c, Perdiz;
d, Starr;
e, Angostura;
$f$, Catan;
$g$, Desmuke;
$h$, Ensor;
i, Marcos;
$j$, Matamoros;
$k$, Tortugas;
1, miscellaneous, Type 1;
$\mathrm{m}$, miscellaneous, Type 2;
$n$, miscellaneous, Type 3 ;
0 , miscellaneous, Type 4;
p, miscellaneous, Type 5;
q, miscellaneous, Type 6 . 


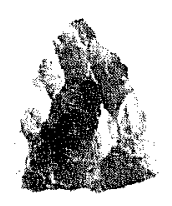

a

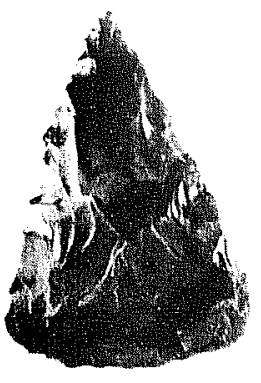

f

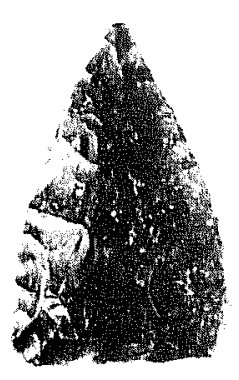

j

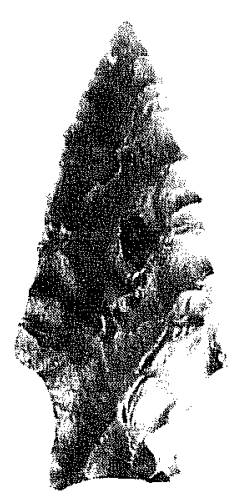

n

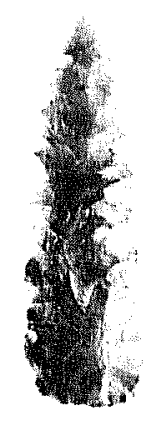

b

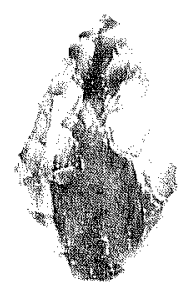

g

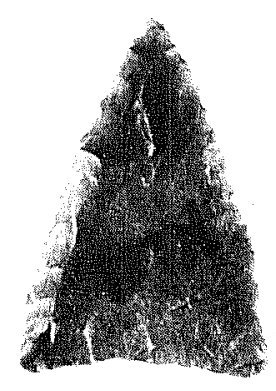

k

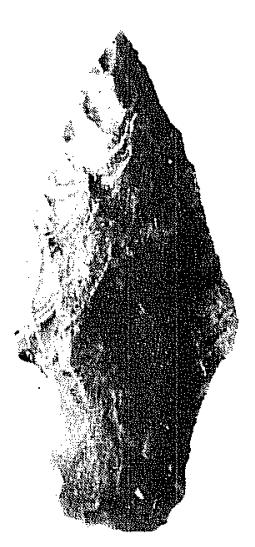

o

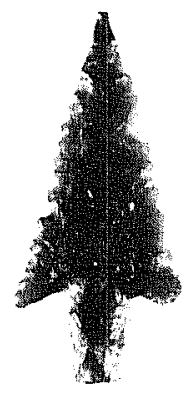

c
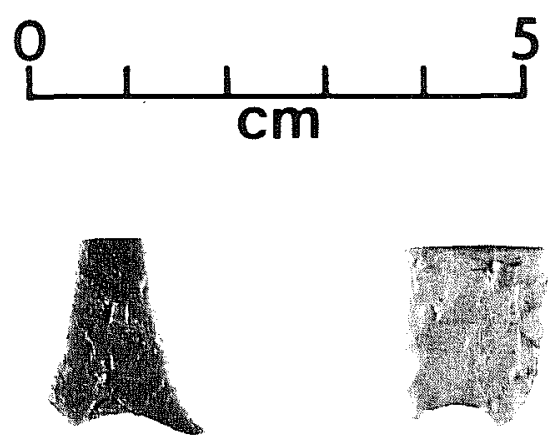

d

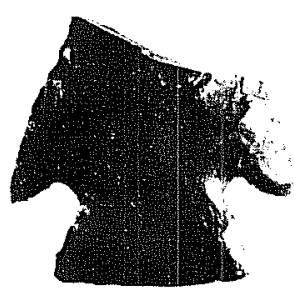

h

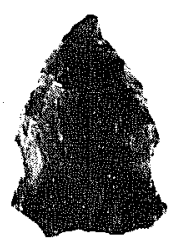

I

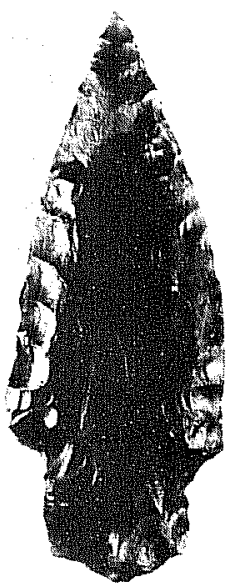

p

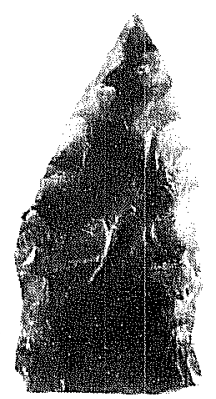

m

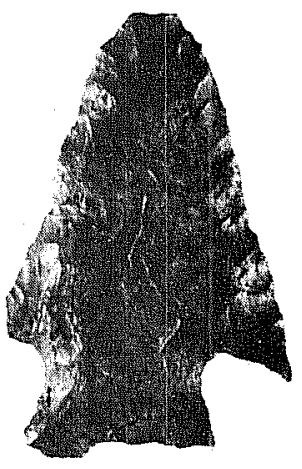

9 
Miscellaneous, Type 4 ( 1 specimen; Fig. 2,0). This point has a stem whose Tateral edges are parallel. The stem has been beveled on the left side of both faces. The blade has convex edges. L:5.0; W:2.3; T:0.9; NW:1.6;

SW:1.3; SL:1.6; WT:9.9.

Miscellaneous, Type 5 ( 1 specimen; Fig. 2,p). This point has convex lateral edges and slight shoulders. The stem is bulbous, al though not extreme. It is similar to Palmillas points. L:5.8; W:2.3; T:0.8; NW:1.5; SW:1.5;

SL:1.3; WT:9.6.

Miscellaneous, Type 6 ( 1 specimen; Fig. 2,q). This patinated dart point has sharp barbs resulting from deep corner notches. The base is concave; the lateral edges are slightly concave. L:(4.6); W:(3.0); T:0.7; NW:1.6; SW:1.9; SL:1.1; WT: (7.7).

Miscellaneous, Type 7 ( 1 specimen; Fig. $3, a$ ). This projectile point has shallow side notches; shoulders are absent. The base has a central indentation and stem corners are rounded. It is similar to Paisano points. L:(2.9); W:1.5; T:0.6; NW:1.3; SW:1.5; SL:1.0; WT:(3.2).

Miscellaneous, Type 8 ( 1 specimen; Fig. $3, \mathrm{~b})$. This slender bipointed biface has lateral edges that are slightly convex. L:5.8; W:2.2; T:0.8; WT:9.1.

Bifaces ( 31 specimens). This category consists of chipped stone artifacts that have had flakes removed from both faces. Several types of tools are discussed as well as several bifaces that probably represent preforms or unfinished artifacts.

Olmos bifaces ( 8 specimens; Fig. 3,c). The Olmos biface as described by Shafer and Hester (1971:2) is a triangular gouge-1ike tool. The wider, thicker end is beveled and considered the distal or working end of the tool. The bit has a scooped-out or curved appearance. Five specimens from Alazan Bay have alternately beveled lateral edges; three are beveled along both lateral edges on each face. One is patinated. L:1.8-3.2; W:2.0-2.3; T:0.61.0; WT:2.0-8.1; Bit Angle: $64^{\circ}-83^{\circ}$.

The distribution of these tools is concentrated in an area from western Kleberg County, across Jim Wells and Duval Counties and into central Webb County. They have been found with Late Prehistoric assemblages and occasionally with Late Archaic dart points (ibid.:7). Occurrences of this tool type in Kleberg County have been reported by Hester (1969a:29-30; 1971:96).

Triangular biface with beveled bit (1 specimen; not illustrated). This specimen is similar to olmos bifaces but is smaller, thinner, and more delicately made. Only one lateral edge has been beveled. The bit or working end is not as pronounced as the bits are on the olmos bifaces. The biface has equilateral sides. L:1.8; W:1.9; T:0.5; WT:1.7.

Perforator (1 specimen; Fig. 3,d). The lateral edges of this specimen contract from the base to form a drill or perforater tip. The distal end is broken. The base is slightly concave. L:(2.4); W:3.6; T:0.6; WT:(4.0). 
Stemmed biface (1 specimen; Fig. 3,e). This large patinated biface was fashioned from silicified wood. It has relatively straight edges and an abbreviated contracting stem. It probably is a dart point preform. $L: 10.1$; W:3.2; T:1.1; WT:32.0.

Triangular, Type 1 ( 3 specimens; not illustrated). These triangular bifaces have pronounced convex basal edges. One lateral edge is convex; the other is concave. L:2.9-3.3; W:1.8-1.9; T:0.6-0.9; WT:3.8-4.6.

Triangular, Type 2 (2 specimens; not illustrated). These triangular bifaces have convex basal edges. The complete specimen has convex lateral edges, one of which is beveled. The other is fragmentary and has straight edges. Measurements of complete specimen: L:3.7; W:1.9; T:0.6; WT:5.1.

Triangular, Type 3 (1 specimen; not illustrated). This triangular specimen has a straight base and straight lateral edges. L:(4.1); W:3.0; T:0.9; WT: (10.0).

Triangular, Type 4 ( 3 specimens; not illustrated). These triangular specimens have been marginally trimmed along both sides of the lateral edges. The bases are straight and slant to one side on two of the specimens. Two of the specimens are patinated. $L: 2.7-3.0 ; W: 2.0-2.3 ; T: 0.4-$ $0.5 ; W T: 2.5-4.6$.

Miscellaneous, Type 1 (2 specimens; not illustrated). One specimen is bi-pointed. Edges are relatively parallel until tapering to distal and proximal ends. The other basal fragment is fashioned from sandstone. The lateral edges taper toward the basal end. Measurements of complete specimen: $L: 4.2 ; W: 1.9 ; T: 0.9 ; W T: 9.6$.

Miscellaneous, Type 2 ( 1 specimen; not illustrated). This biface has parallel edges that taper to the distal tip. The base is convex. $L: 4.8 ; W: 2.3 ; T: 0.9 ; W T: 12.5$.

Miscellaneous, Type 3 (1 specimen; not illustrated). The basal fragment has parallel lateral edges and a concave base. $L:(2.6) ; W: 2.4 ; T:(0.9)$.

In addition to the above mentioned bifaces, seven distal fragments were also collected.

Uniface (1 specimen; not illustrated). This triangular specimen has convex lateral edges, a slightly concave base and a plano-convex cross-section. L:2.3; W:1.3; T:0.8; WT:2.6.

Trimmed Flake ( 1 specimen; not illustrated). This blade has been trimmed along both lateral edges and along the end opposite the platform. L:3.2; W:1.4; T:0.3; WT :2.4. 
SHELL ARTIFACTS

Pendant (1 specimen; Fig. 3,k). Made from the whor1 of a conch she11, this specimen is elliptical in outline. Two perforations made by conical drilling from the ventral side are collateral on the upper part of the pendant. The edges are smoothed and rounded. Both surfaces exhibit polish. L:3.7; $W: 2.2 ; T: 0.2 ; W T: 3.3$.

Bead blank ( 1 specimen; Fig. 3,g). This undrilled specimen is made from the columella of the lightning whelk conch. The surface is smoothed and slightly polished. L:6.3; D:1.2; WT:20.5.

Adze (1 specimen; Fig. 3,h). This tool is made from a conch whorl. The highly polished distal end is beveled. Microscopic examination shows nibbling along the distal or bit end. One lateral edge exhibits varying degrees of smoothing. L:7.2; W:5.5; T:0.6; WT:38.8.

Bead (1 specimen; Fig. 3,i). This Noetia ponderosa shell bead is conically driTled from the dorsal side. Similar specimens were found associated with burials at the Floyd Morris Site (Collins, Hester and Weir 1969:142).

Arrowpoints ( 2 specimens; Fig. $3, j$ ). Both points were made of Sunray clam (Macrocallista nimbosa) shell and are triangular. The larger one is basically unifacial with only minimal bifacial edge-sharpening and shaping on the ventral surface. The smaller point is bifacial. L:1.7-2.6; W:1.3-1.5; T:0.3; WT: 0.7-0.8.

Unifacial "scraper" (1 specimen; Fig. 3,1). This irregularly shaped specimen has a series of flake scars along one edge. It is fashioned from a piece of Sunray Clam (Macrocallista nimbosa) shell. It could have functioned as a scraper or possibly as a cutting implement. $L: 4.0 ; W: 3.9 ; T: 0.4 ; W T: 10.7$.

Six other fragments of Sunray clam shell were recovered. The edges appear modified although flake scars similar to the ones on the unifacial object (mentioned above) are noticeably absent. The breaks could be fortuitous.

A "nest" of six complete Sunray clam shells were found. The significance of this is unknown. They were apparently arranged together (one inside the next). A similar nest of bivalves was recorded in several burials at a site in San Patricio County (Hester and Corbin 1975:521-522). The edges of these specimens were heavily worn and Hester and Corbin postulated that they were used to dig the graves. The specimens in the Alazan Bay collection do not have worn edges.

\section{ANIMAL BONE ARTIFACT}

Drilled Bone (1 specimen; Fig. $3, \mathrm{~m}$ ). A rabbit bone (Lepus californicus) with a naturat hole below the articular end was recovered. The specimen exhibits some weathering although parts of the bone are highly polished. The broken end is at an angle with rounded and polished edges. The specimen was probably used as an ornament. L:6.4; D:0.6; WT:2.0. 
HUMAN BONE ARTIFACT

Ulna ( 1 specimen; Fig. $3, f$ ). This human ulna artifact has a groove and snap cut approximately $8 \mathrm{~cm}$ below the top of the articular end. At the Floyd Morris site human radii associated with burials have similar groove and snap cuts (ibid.:138). The cancellous material was removed from the interior of the bone. Human bone artifacts from the southern Texas coastal region have been described and discussed by Hester (1969a, 1969b).

\section{GROUND STONE ARTIFACT}

A dark red sandstone fragment has been ground on one surface. The two remaining edges were also ground and the corner is rounded. $L:(4.7)$; $W:(4.7) ; T: 1.2$; WT: (8.2).

\section{POTTERY}

Eleven potsherds were recovered; the majority are typical of Rockport ware pottery. The interiors of four sherds have an asphaltum coating, presumably for water-proofing; three of these also have traces of asphaltum on the exterior. Five potsherds have scoring on the interior surfaces with smooth exterior surfaces. Calhoun (1961:321-322) attributes this type of impression to the aboriginal use of ribbed marine bivalve shells in the manufacture of pottery. The shells were used in shaping and smoothing the interiors and exteriors of pottery vessels (ibid.:321-322). Two other sherds were undecorated.

HUMAN SKELETAL MATERIAL

Two mandible fragments and four teeth were collected. The mandible fragments represent separate individuals since they are both left elements; one specimen is larger than the other. The teeth have worn surfaces. The human bone fragments were found in a wash with a large quantity of animal bones.

\section{Summary and Conclusions}

Information regarding the prehistoric culture and 1 ifestyle of aboriginal groups along the central and southern coast of Texas has been limited in interpretations due to the lack of comprehensive investigations, particularly controlled excavations. Two cultural phases, the Archaic and Late Prehistoric periods, have been identified but temporal groupings within these two phases have not yet been defined.

The Archaic period is characterized by dart points, conch shell artifacts, bone tools and ornaments, triangular bifaces, heavy bifaces and unifaces, tubular stone pipes and ground stone fragments (Hester 1969a:55). The Aransas Complex has been used to describe most Archaic assemblages occurring along the central 
Figure 3. Artifacts from Alazan Bay.

a, miscellaneous, Type 7;

b, miscellaneous, Type 8;

$c$, Olmos biface;

d, perforator;

$e$, stemmed biface;

$f$, human ulna artifact;

$g$, columel la bead blank;

$h$, conch shell adze;

$i$, Noetia ponderosa she11 bead;

$j$, clam shell arrow point;

$k$, conch shell pendant;

1, clam she11 "scraper";

$\mathrm{m}$, bone artifact. 


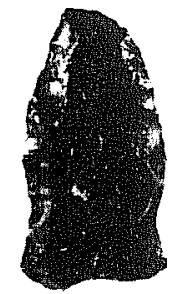

a
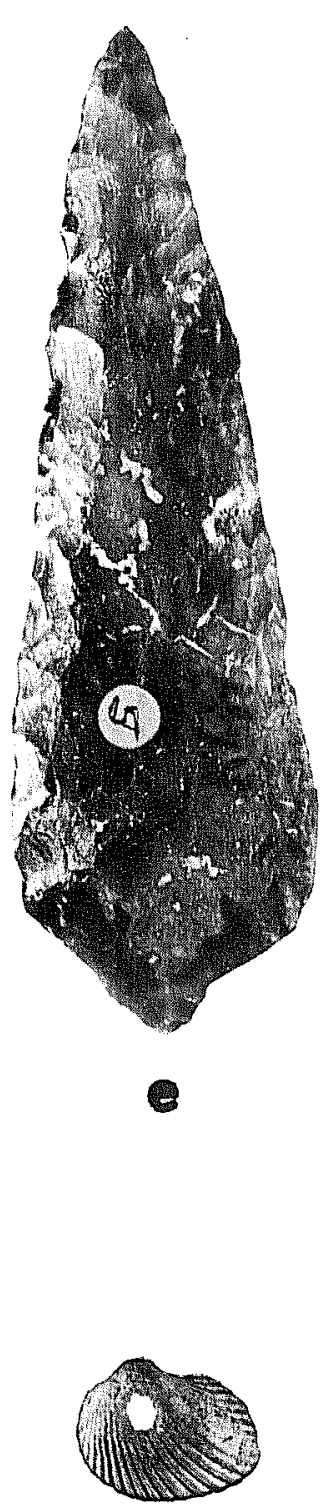

I

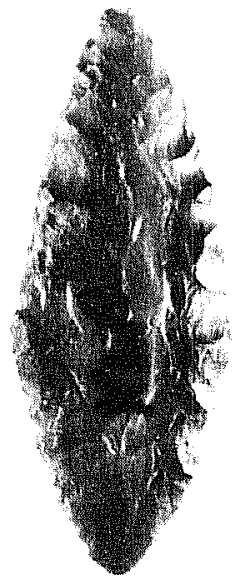

b
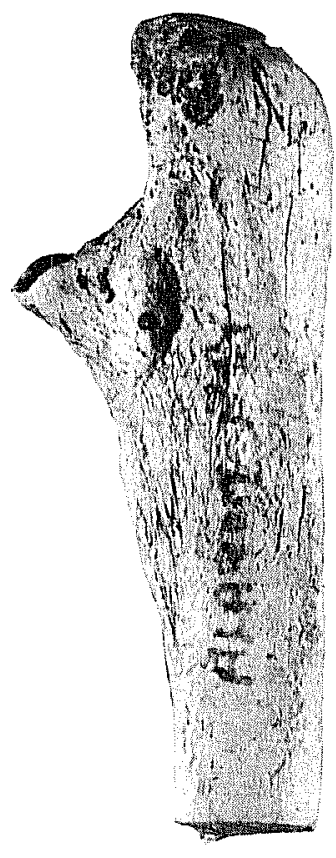

$f$
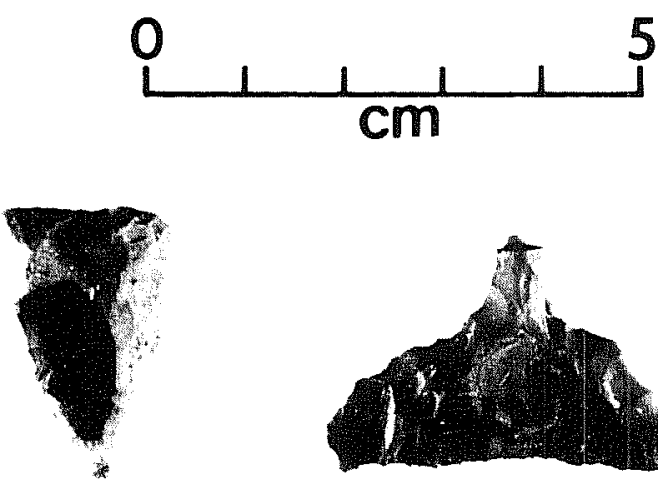

C

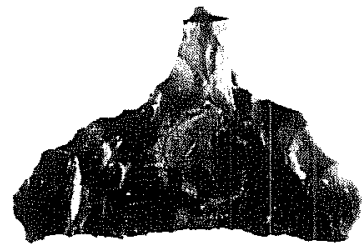

d
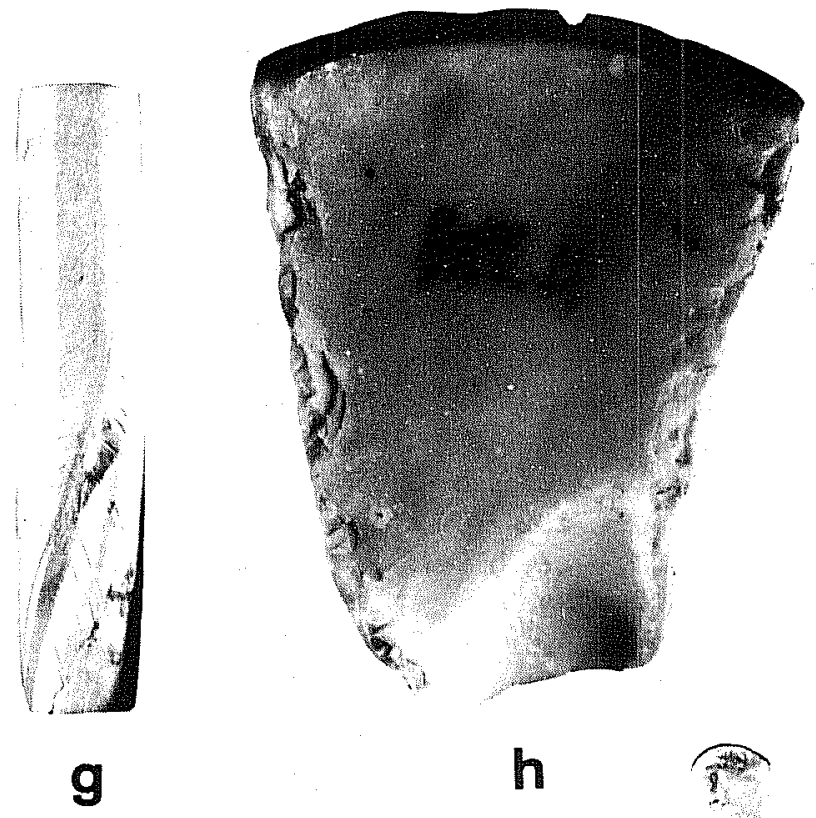

h
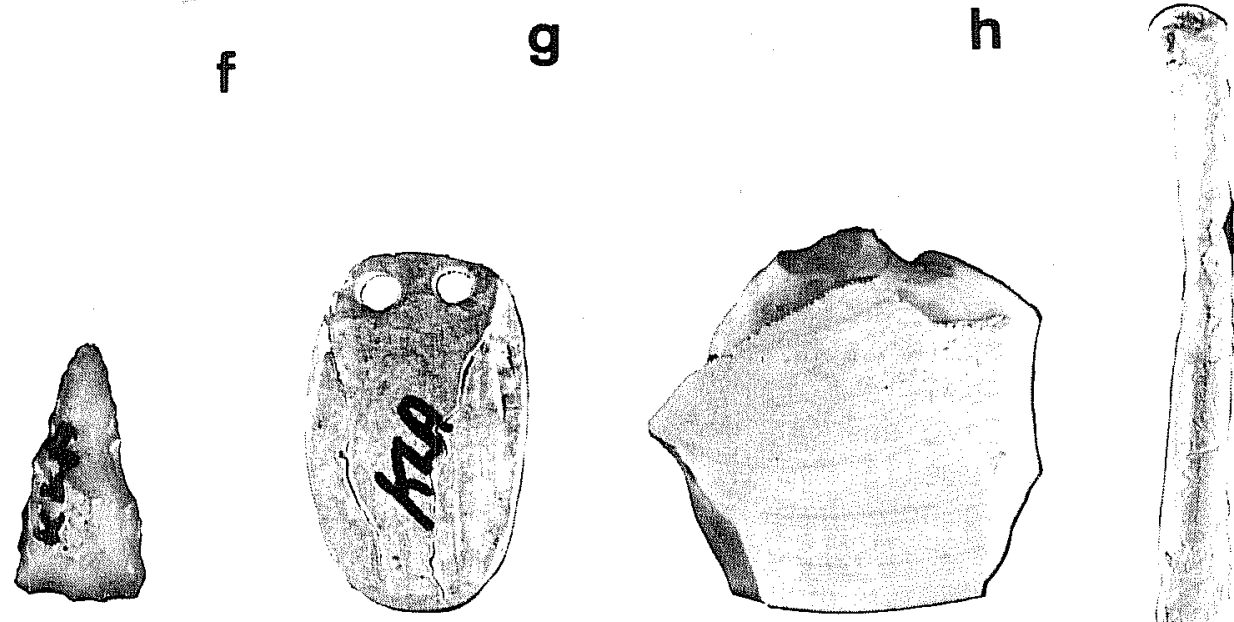

k
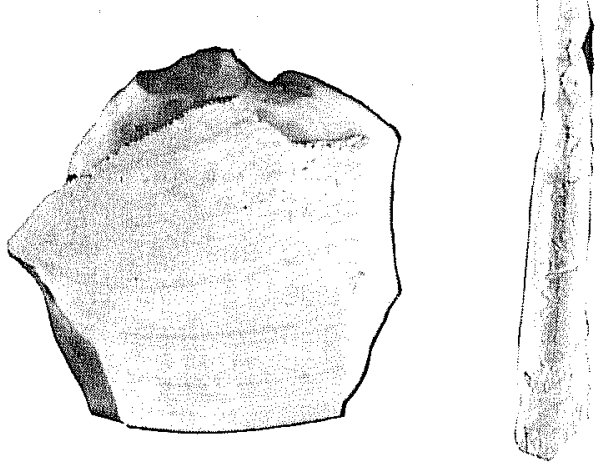

I

I 
and southern coast although the complex was initially constructed to define cultural debris from the Aransas Bay area (Corbin 1974:31). Dart points include Abasolo, Ensor, Kent, Lange, Marcos, Matamoros and Tortugas. Shell artifacts, particularly conch, and bone artifacts are common. Small flake drills, end scrapers, triangular bifaces, tubular stone pipes and ground stone items also occur.

Archaic sites along the coast appear to represent rather brief periods of occupation (Hester 1969a:55). However, Campbell (ibid.) postulates that the Archaic was quite prevalent in the Alazan Bay area. (The owner of the collection documented in this report agrees with that observation.) Archaic manifestations have also been located along the nearby portions of Padre Island and along the eastern portion of Cayo del Grullo (Hester 1969a:55)

The artifacts from Alazan Bay described in this report that can be attributed to the Aransas Complex are shown in Table 1. Other Archaic dart points include Desmuke, Lerma, Nolan and Yarbrough. Olmos bifaces have been found with Late Archaic and Late Prehistoric point types. The use of these tools probably originated in Late Archaic times and continued into Late Prehistoric times (Shafer and Hester 1971:7).

The Late Prehistoric period is characterized by arrow points, pottery, sma11 bifaces and unifaces, flake drills, shell beads, she 11 projectile points and perforated canine teeth (Hester 1969a:56). Artifact assemblages attributed to this period are more abundant than Archaic remains. Late Prehistoric sites are common along the western portion of Cayo del Grullo (ibid.).

The Rockport Complex includes Perdiz, Cliffton, Scallorn and Fresno arrow points, Matamoros and Catan dart points, sma11 flake drills, end scrapers, sandy-paste pottery, triangular she 11 arrow points, shell beads, perforated animal canines, shel1 scrapers and shell pendants (Hester 1969a:7). Artifacts from the Alazan Bay area are shown in Table 1. Notable Rockport Complex traits include six Perdiz points, two triangular she11 arrow points, one conch shell pendant and Rockport pottery sherds. Other Late Prehistoric sites have been recorded along the western shores of Cayo de1 Grul10 (ibid.:56). The Loyola Beach Site artifacts from this time period include Perdiz points, triangular arrow points, Rockport pottery, Matamoros points, Catan points, and shel1 scrapers and adzes (Hester 1971:96,98).

The Brownsville Complex in the Rio Grande delta region includes Fresno, Starr and Cameron arrow points, small circular unifaces, unifacial end scrapers and perforated animal canines. Large quantities of marine shell artifacts include projectile points, beads, Macrocallista nimbosa scrapers, Noetia ponderosa beads, conch shel1 gouges, conch columella gouges and conch pendants. Many of the artifacts collected from the Alazan Bay locality can be attributed to the Brownsville Complex (see Table 1). Site $41 \mathrm{KL} \mathrm{45,} \mathrm{located} \mathrm{on} \mathrm{the} \mathrm{eastern}$ side of Cayo del Grul10, contained similar artifacts including a polished conch columella rod (which may be similar to the bead blank described in this report), conch whorl adzes, Perdiz and Starr arrow points and Rockport pottery (Hester 1969a:57). Brownsville Complex traits from the Loyola Beach Site include Cameron and Starr points, Macrocallista nimbosa shel1 scrapers and conch she11 adzes (Hester 1971:96). 
TABLE 1. ARTIFACTS FROM ALAZAN BAY AND THEIR OCCURRENCE IN THE ARANSAS, ROCKPORT AND BROWNSVILLE COMPLEXES

Aransas Complex Traits

Artifacts from Alazan Bay

Abasolo points

Ensor points

$X$

Kent points

Lange points

Marcos points

Matamoros points

Morhiss points

Refugio points

Tortugas points

$X$

Flake dri11s

End scrapers

Triangular bifaces

Conch whorl adzes

$X$

Conch columella gouges

Bone artifacts

Tubular stone pipes

$x$

$X$
$X$

Ground stone artifacts

Rockport Complex Traits

Catan points

Matamoros points

$X$
$X$

Clifjton points

Fresno points

Perdiz points

Scallorn points

$x$

Snub-nose end scrapers

Flake drills

Rockport pottery

Shell arrow points

She 11 beads

She11 pendants

Conch scrapers

Perforated canines

Brownsville Complex Traits

Catan points

Matamoros points

Cameron points

Fresno points

Starr points

Bipointed drills

Circular unifaces

Unifacial end scrapers

Shell scrapers

Shell pendants

$X$
$X$
$X$
$X$
$X$
$X$ 
TABLE 1. (continued)

Brownsville Complex Traits

Artifacts from Alazan Bay

Shell beads

$X$

Shell awls

Shell arrow points

$x$

Conch columella gouges

Conch adzes

Bone artifacts

Stone tubular pipes

Sandstone and pumice abraders

The artifacts from Alazan Bay probably represent intermittent occupations during the Archaic and Late Prehistoric periods. Chipped stone materials predominate but this could be attributed to arbitrary sampling at the site. Shell artifacts are typical of those found at other central and southern Texas coastal sites. The presence of several human bone elements probably represents an eroded or disturbed burial. Some of the artifacts, including the modified human ulna, Noetia ponderosa bead and conch pendant might represent burial goods. Similar $i$ tems have been found associated with burials at other coastal localities (Hester et al. 1969; Hester 1969a).

The artifact assemblages from central coastal sites appear to represent a mixture of several cultural entities. Several of the dart point styles (i.e., Catan, Ensor, Matamoros and Tortugas) are common in the south Texas region. The occurrence of these dart points could represent seasonal food gathering excursions to the coast by south Texas groups. If such interactions with south Texas groups were common for the coastal peoples, the south Texas dart point styles could have become adopted traits and integrated into their culture. Artifacts commonly found in abundance along the extreme southern coast appear to a lesser degree along the central coast. Interaction among the various coastal groups is evident, al though the extent of such interaction remains unknown.

Additional surveys along the coast and controlled excavations at a number of sites are needed to interpret the varied artifact forms found along the coast of Texas. The extent of Archaic occupations remains to be determined. Various complexes need to be revised with the extent of cultural interactions among various groups adjacent to and along the coast of Texas further clarified. 


\section{REFERENCES CITED}

Calhoun, C. A.

1961 Scored Pottery of the Texas Coastal Bend. Bulletin of the Texas Archeological Society 32:321-325.

Campbe11, T. N.

1947 The Johnson Site: Type Site of the Aransas Focus of the Texas Coast. Bulletin of the Texas Archeological and Paleontological Society 18:40-75.

1958 Archeological Remains from the Live Oak Point Site. Texas Journal of Science 10:423-442.

Collins, M. B., T. R. Hester and F. A. Weir

1969 The Floyd Morris Site (41 CF 2). A Prehistoric Cemetery Site in Cameron County, Texas. In T. R. Hester et al., Two Prehistoric Cemetery Sites in the Lower Rio Grande Valley of Texas. Bulletin of the Texas Archeological Society 40:119-146.

Corbin, J. E.

1974 A Model for Cultural Succession for the Coastal Bend Area of Texas: Bulletin of the Texas Archeological Society 45:29-54.

Fitzpatrick, W. S., J. Fitzpatrick and T. N. Campbell

1964 A Rockport Black-on-Gray Vessel from the Vicinity of Corpus Christi, Texas. Bulletin of the Texas Archeological Society 35: 193-204.

Hester, T. R.

1969a Archeological Investigations in Kleberg and Kenedy Counties, Texas in August, 1967. State Building Commission Archeological Program 15.

1969b Human Bone Artifacts from Southern Texas. American Antiquity $34(3): 326-328$.

1971 Loyola Beach: An Example of Aboriginal Adaptation to the Marine Environment of the Lower Texas Coast. Florida Anthropologist 24(3): $91-106$.

Hester, T. R., M. B. Collins, F. A. Weir and F. Ruecking, Jr.

1969 Two Prehistoric Cemetery Sites in the Lower Rio Grande Valley of Texas. Bulletin of the Texas Archeological Society 40: 119-166. 
Hester, T. R. and J. E. Corbin

1975 Two Burial Sites on the Central Texas Coast. The Texas Journal of Science 26(3-4):519-528.

Krieger, A. D.

1953 Récent Developments in the Problem of Relationships Between the Mexican Gulf Coast and the Eastern United States. In Huastecos and Totonacos y sus Vecinos, Revista Mexicana de Estudios Antropologicus 13(2-3):497-518.

Shafer, H. J. and T. R. Hester

1971 A Study of the Function and Technology of Certain Bifacial Tools from Southern Texas. Texas Historical Survey Committee, Archeological Report 20.

Suhm, D. A., A. D. Krieger and E. B. Jelks

1954 An Introductory Handbook of Texas Archeology. Bulletin of the Texas Archeological Society 25. 
THE LA PALOMA MAMMOTH SITE, KENEDY COUNTY, TEXAS*

Raymond W. Suhm

with notes on the archaeology by Thomas R. Hester

\section{Introduction}

In April 1975, the remains of extinct Late Pleistocene mammals were discovered on the coastal plain of south Texas. The fossil site, designated $41 \mathrm{KN} 78$ in the files of The University of Texas at Austin, Texas Archeological Research Laboratory, is located in stock tanks on the La Paloma Ranch in Kenedy County, about $56 \mathrm{~km}$ southwest of Kingsville, Texas (Fig. 1).

The bones were initially discovered in April 1975 by Allen Mittag while excavating a stock tank with a bulldozer in the relict drainage system on the Palo Blanco River. After bulldozing was suspended at the initial site (site 1), three additional stock tanks were dug in the same region. Bulldozing was halted in all tanks when bones of Late Pleistocene faunas were discovered in each at approximately the same depth as in site 1. The four sites are referred to by number in the sequence in which they were initially uncovered (Fig. 2). Permission to examine and excavate the bones was granted by the ranch owners, Mr. and Mrs. Fred Erck of Alice, Texas.

Excavations in 1975 were concentrated in site 1, where a mammoth (Mammuthus columbi) estimated to be $60 \%$ complete, and various bones and bone fragments belonging to ground sloth, mastodon and horse were encountered (Fig. 3). At site 2, a femur and molars of a mammoth and an articulated skeleton of Bison antiquus were uncovered but not removed. Sites 3 and 4 were investigated the least, but horse teeth and various unidentified bones were present. Five-inch rains in June 1975 filled a 11 the pits (sites 1-4) and the tanks remained filled with water. Fortunately, however, during the rain-free months of April 1975 the semi-articulated mammoth skeleton was removed through an intensive excavation effort under Suhm's direction.

The bones are contained in clayey sand alluvium of the ancestral Palo Blanco River at a depth of 1.2 to $1.8 \mathrm{~m}$. Radiocarbon dates for the bones range in age from 8080 to 9830 B.P. These dates are consistent with observed stratigraphy. The age of the bones is somewhat younger than the accepted dates marking the end of the Pleistocene (ca. 10,000 B.P.). In terms of glacial chronology, the deposits are assigned to the Cochrane and Valders substage (Haynes 1970:80) which post-date the extinctions of the well known Rancholabrean faunas. Therefore, the La Paloma faunas may represent some of the last to have inhabited North America. Pleistocene vertebrates have been recovered from widely scattered localities elsewhere in south Texas but are poorly dated, e.g., Ingleside, Texas (Lundelius 1972), Bee County, Texas (Se11ards 1940) and Sinton, Texas (Hay 1926).

*An earlier version of this paper, authored by Suhm, appeared in TAIUS, Journal of Texas A\&I University XI(1):13-36, Kingsvi11e, 1978. 


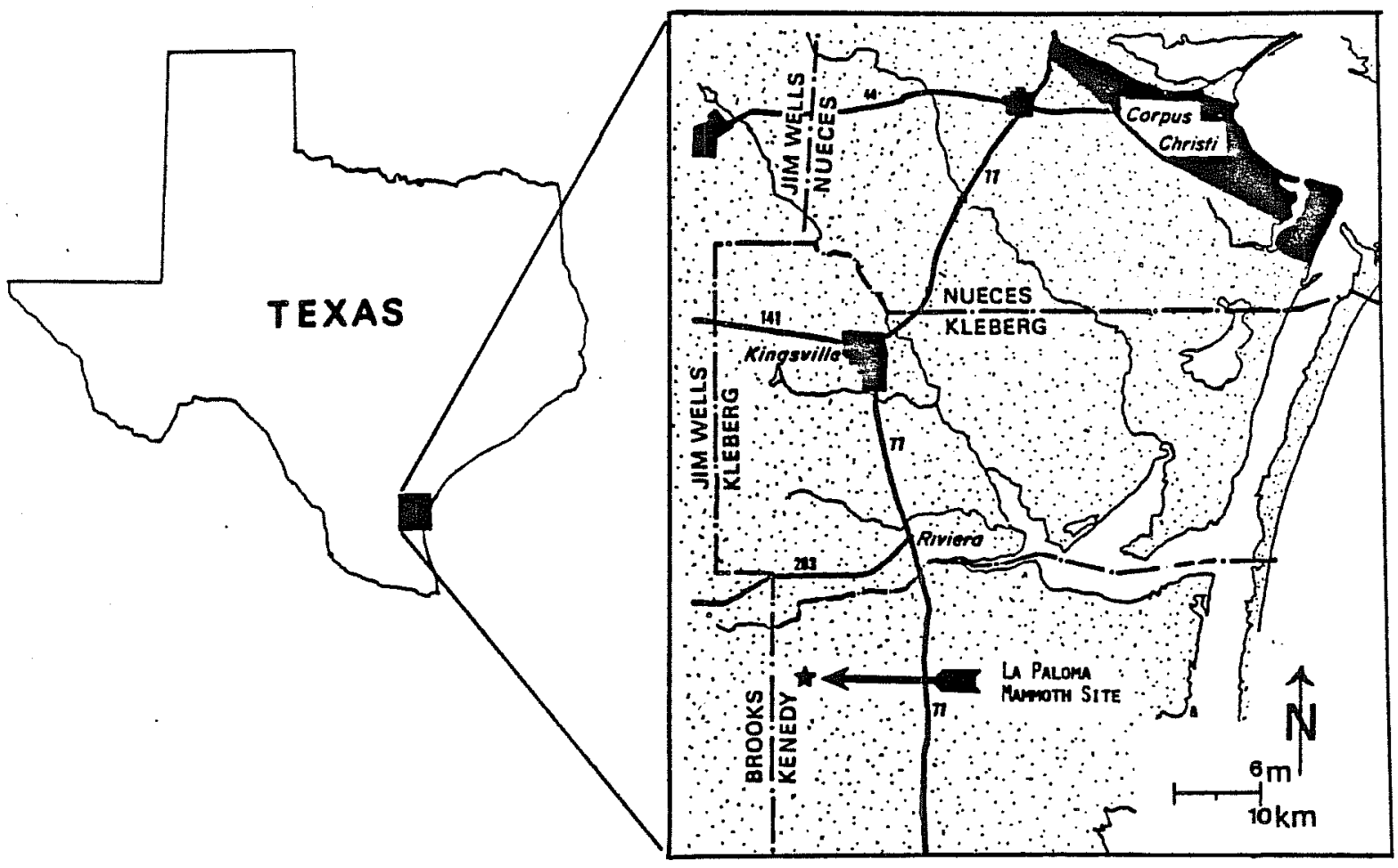

Figure 1. Map Showing the Location of the La Paloma Site, Northwestern Kenedy County, Texas. 


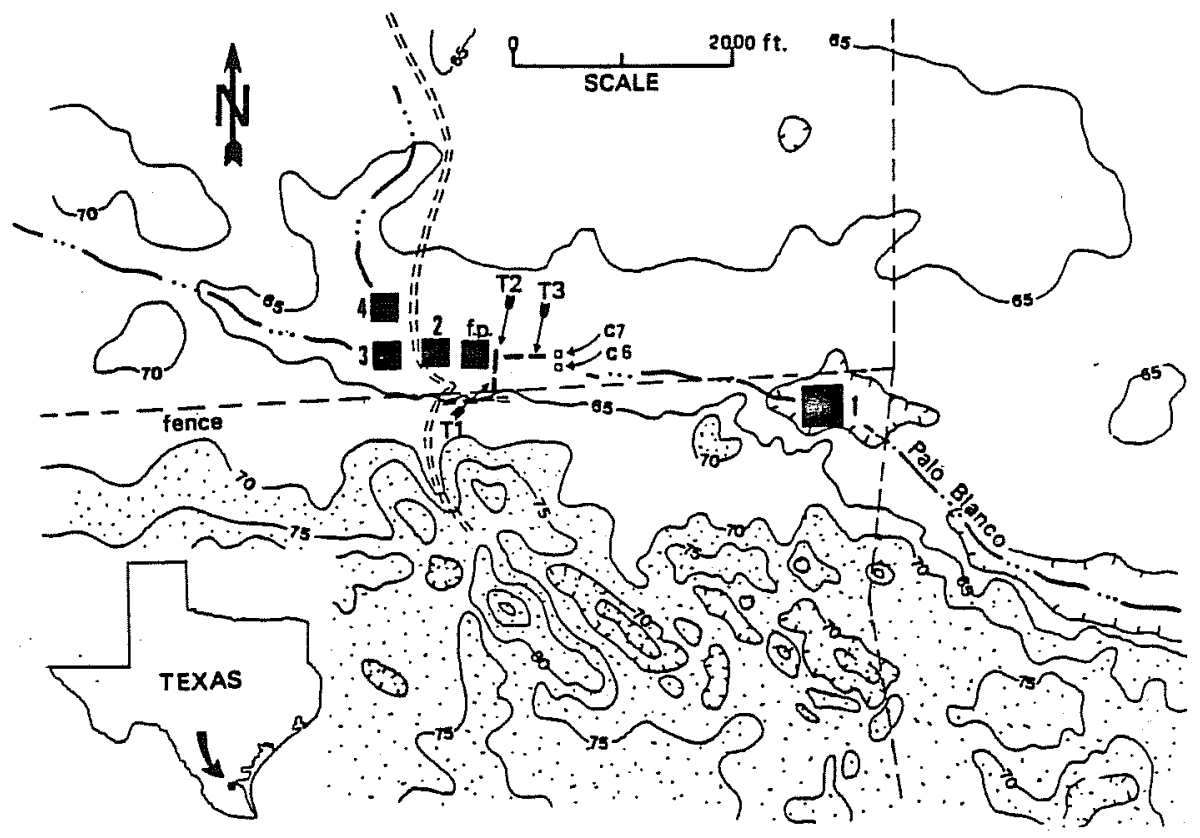

Figure 2. La Paloma Site. Shown here is part of the La Paloma Ranch in Kenedy County, with the locations of four stock tanks (sites 1-4), an older tank referred to as the fishing pond (f.p.), major trenches (TI-T3) and two of seven core holes (C6-C7). The faunal sites are in the alluvium of the Palo Blanco River. This now-intermittent stream was much larger during the Pleistocene. Contours are in feet above sea level. Stippled area is the northern edge of the South Texas Sand Sheet which has buried the river channel at several places along its course. 
Chipped stone artifacts were recovered from stock tank backdirt, but none were found in direct association with the Pleistocene mammals. It is hoped that evidence gathered from the La Paloma site will help to fill the gaps that currently exist in the faunal record of Late Pleistocene times in southern Texas.

\section{Excavation Techniques}

An assortment of tools ranging from shovels to screwdrivers were used to excavate the mammoth at site 1. Heavy equipment, a backhoe and bulldozer, were used to define the periphery of the bone array on all sides and to assist in removing loose sediment from the margins of the excavation pits (Fig. 4). A horizontal grid system of one meter squares was employed at site 1 by establishing northsouth and east-west lines. Excavation units were staked and referenced from the southeast corner. The bones were numbered, photographed and mapped in a fashion similar to the procedures used by Saunders (1975) at the Boney Spring mastodon site. Every specimen was oriented, its position in the tank noted, and its association with other objects plotted. Figure 5 illustrates the distribution of bones excavated from site 1 .

The sandy sediment surrounding the bones was easy to remove. The bones cleaned in the field were friable and damp, requiring application of a diluted solution of water-soluble glue to facilitate preservation and their removal. The bones at site 2, occurring at a depth similar to those of site 1 , were crumbly and partially calcified as were portions of the sand and clayey sand matrix. Because of this condition, shellac diluted with alcohol by one-half, was applied. In contrast to bones at site. 1 , those at site 2 could not be removed before rains filled the tank. A jacket of plaster of paris was applied to the larger bones before removal from the field site to Texas A\&I University Conner Museum. The plaster and glue solutions were removed in the museum and the bones were cleaned and prepared for display.

Small fragments of bone and rounded chert pebbles were found in the sedimentary matrix at site 1. This matrix was not screened; insufficient time, personnel and funds precluded this task. Sedimentary material from test pits and trenches east of site 2 was systematically screened through $1 / 4-$ inch $(6 \mathrm{~mm})$ mesh screens in 1976 by Herman Smith.

\section{Geomorphic Setting}

The separate bone occurrences on the La Paloma Ranch are grouped along the obscure drainage course of the intermittent Palo Blanco River. In this immediate area, the Palo Blanco separates the South Texas Sand Sheet on the south from the sandcovered and partly-deflated Beaumont Clay plain on the north (Figs. 2,6). The sand sheet is an extensive area of dune topography that extends west and south from Baffin Bay. The sand accumulation is generally stabilized by brush, grass and live oak mottes, but some areas have active sand dunes (Fig. 6). Immediately north of the buried Palo Blanco River channel is a plain marked by abundant eastwest oriented playa lakes which are remnants of Late Pleistocene and dune topography. This plain, termed "Sarita 0ld Dune Plain" (Corpus Christi Geological Society 1958), 


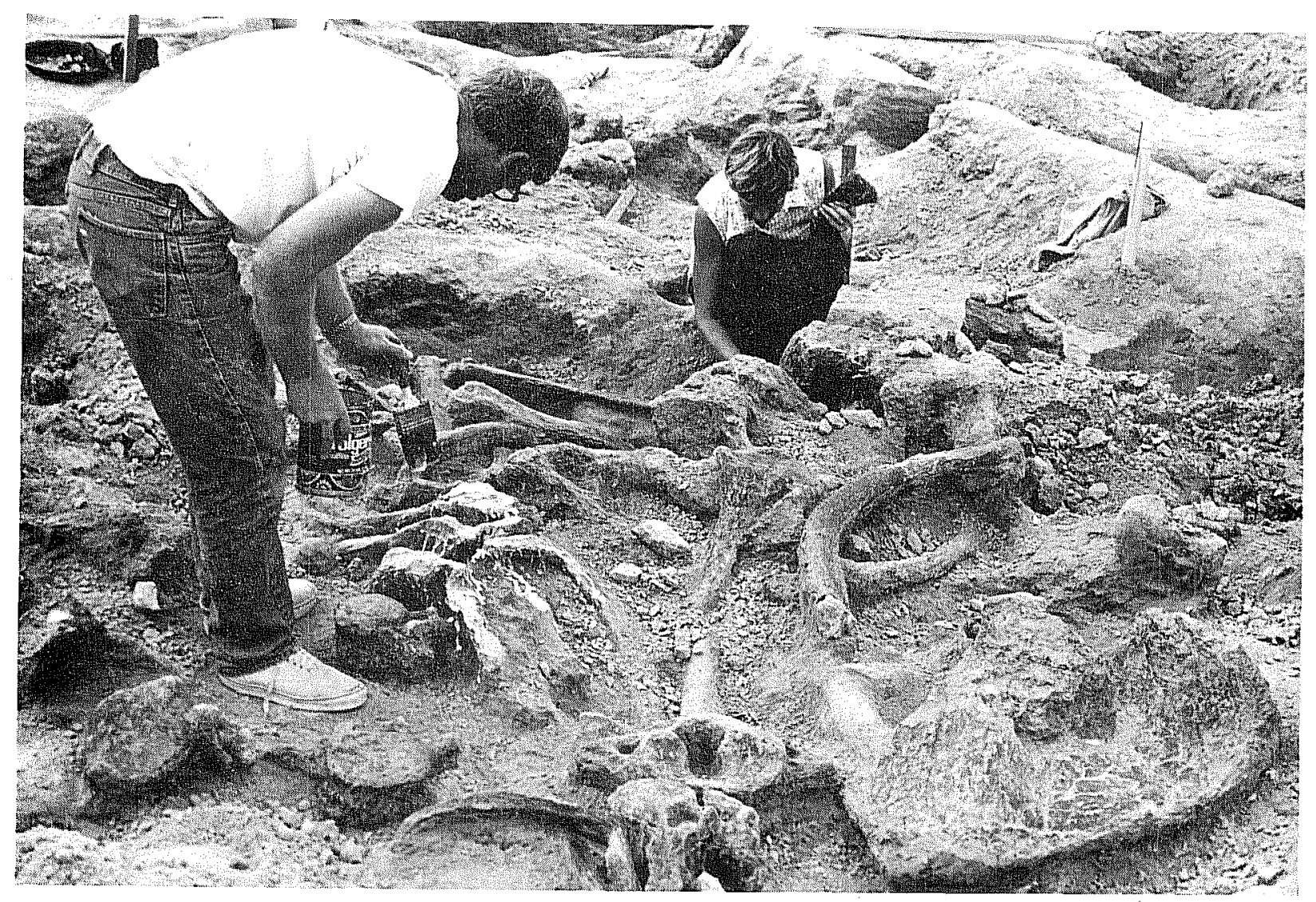

Figure 3. La Paloma Site. The mammoth at Site 1, May, 1975 excavations. The vertebral column, ribs and sacrum are visible. Note the posterior occurrence of the atlas vertebra.

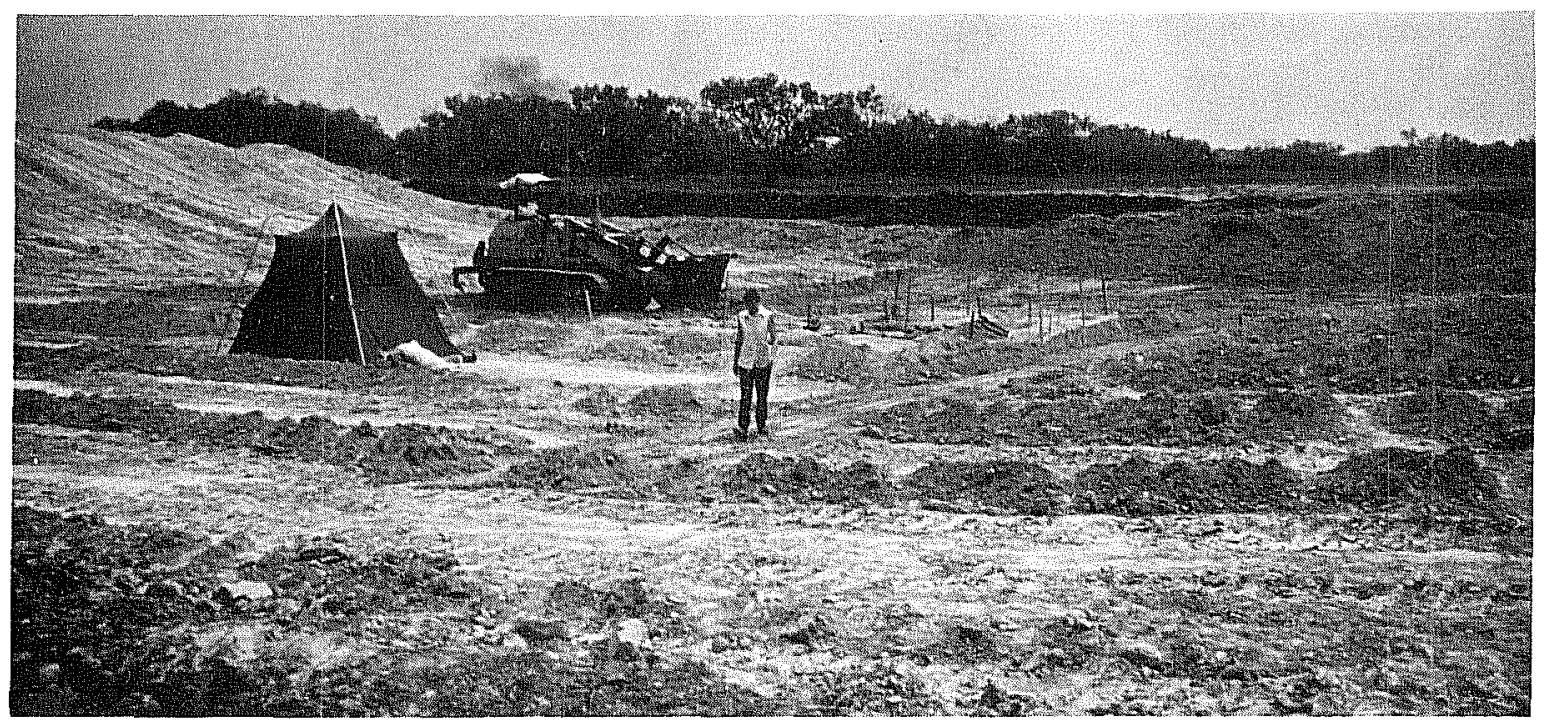

Figure 4. La Paloma Site. Heavy equipment used to remove overburden and define limits of mammoth at site 1. Note the shallow occurrence of the bone array. 


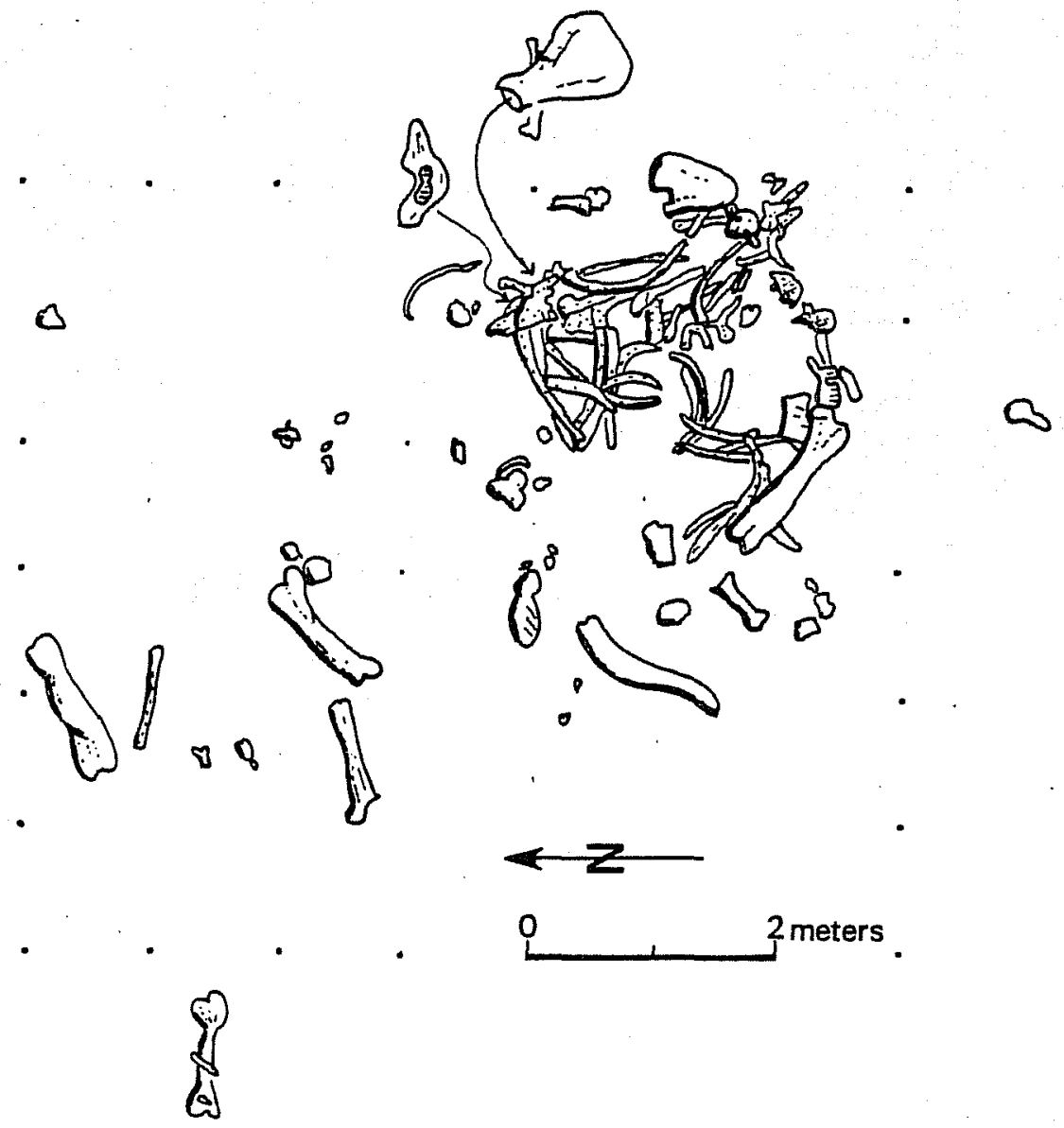

-Figure 5. La Paloma site. Map of the mammoth at site 1 showing the excavated portion. Grid is in square meters. Dots indicate grid stakes. 
was, and is, being invaded by more recent dunes of the South Texas Sand Sheet which have covered parts of the Palo Blanco River. As will be discussed later, the depositional history of the sand sheet is important to interpretation of La Paloma stratigraphy.

Two major types of soils in the area are separated from one another by a line formed by the northern edge of the South Texas Sand Sheet. Soils north of the sand sheet, called Medio soils (U.S.D.A. 1960) are gray brown to light brown gray, friable, loamy sand 12 to 15 inches $(30$ to $38 \mathrm{~cm}$ ) thick that change abruptly downward into mottled, yellow brown, firm, massive sandy clay. The Medio soils form on nearly level surfaces which support mesquite and grass. The soils forming the surface of the Palo Blanco drainage system are similar to Medio soils and included with them, but change downward into massive clayey sand. "Saw grass" covers the surface of the old channel today. The soils of the sand sheet, referred to as Tivoli sands (U.S.D.A. 1960), are pale brown to light yellow brown and from 4 to 10 inches $(10$ to $25 \mathrm{~cm}$ ) thick resting on pale yellow fine sand. This soil type occurs in areas with undulatory to hummocky dune topography, covered with oak trees and grass.

The present Palo Blanco River channel follows essentially the same channel it did in Late Pleistocene times as substantiated by bone occurrences in alluvium. The channel of the Palo Blanco River westward from the La Paloma Ranch to the vicinity of Falfurrias is readily ascertained from topographic maps. Its relict course is characterized by broad meanders with definitive relief but with an absence of water except after heavy rains. During the humid Wisconsin glacial stage of the Pleistocene, the Palo Blanco was probably characterized by large water flow on a flat, nearly level plain. The size of the Palo Blanco channel suggests that in pluvial times it would have been comparable to any one of the several large, sluggishly moving rivers traversing the coastal plain of Texas today. Undoubtedly, this river was once an important source of water for animals as suggested by the diverse assemblage of bones at a depth of 4 to 8 feet $(1.2$ to $2.4 \mathrm{~m})$ in the alluvium fill.

East of the La Paloma Ranch the meander pattern of the Palo Blanco River is difficult to determine because it is obscured in part by northwesterly trending sand dunes of the South Texas Sand Sheet. However, its earlier course may be inferred from sinuous ponds and traces of meanders that exist between stabilized sand dunes. The mouth of the ancient Palo Blanco River is not visible but is a buried channel mapped by Behrens (1963) at an embayment entering Baffin Bay from the south (Fig. 6).

The thickness and geometry of the sedimentary fill of the Palo Blanco River valley was determined by seismographic study (Fig. 2). A seismic survey was selected over conventional coring and trenching because of lower cost and reduced time of operation. Different sedimentary units were determined from the velocity of seismic wave propagation through the sedimentary materials. A portable refraction seismographic unit, model GT-2A, manufactured by Geo Space Corporation, was used in the seismic investigations.

The seismograph contained a 360 -foot $(110 \mathrm{~m})$ cable spread with geophones spaced at 30 -foot $(9 \mathrm{~m})$ intervals. The 30 -foot $(9 \mathrm{~m})$ spacings were not used because of the shallow depth of the alluvium and weak signals transmitted through the low 
Figure 6. Geomorphic Map for Parts of Kenedy and Kleberg Counties, South Texas. Shown here is a reconstruction of the Palo Blanco River as established by relief, vegetation, abandoned channels and sand-barred lakes interpreted from high altitude aerial photographs and topographic maps.

The course of the Palo Blanco River is interrupted in places by recent wind-blown sand of the South Texas Sand Sheet. "The water of Cayo Lake and Laguna Salada was backed up by the damming action of sand. What was once the mouth of the river at Baffin Bay (dashed lines) is inferred from seismic profiles (Behrens 1963). North of the Palo Blanco River is the Sarita 01d Dune Plain, a remnant of an earlier but deflated Late Pleistocene sand plain. It is marked by abundant east-west trending playa lakes. 


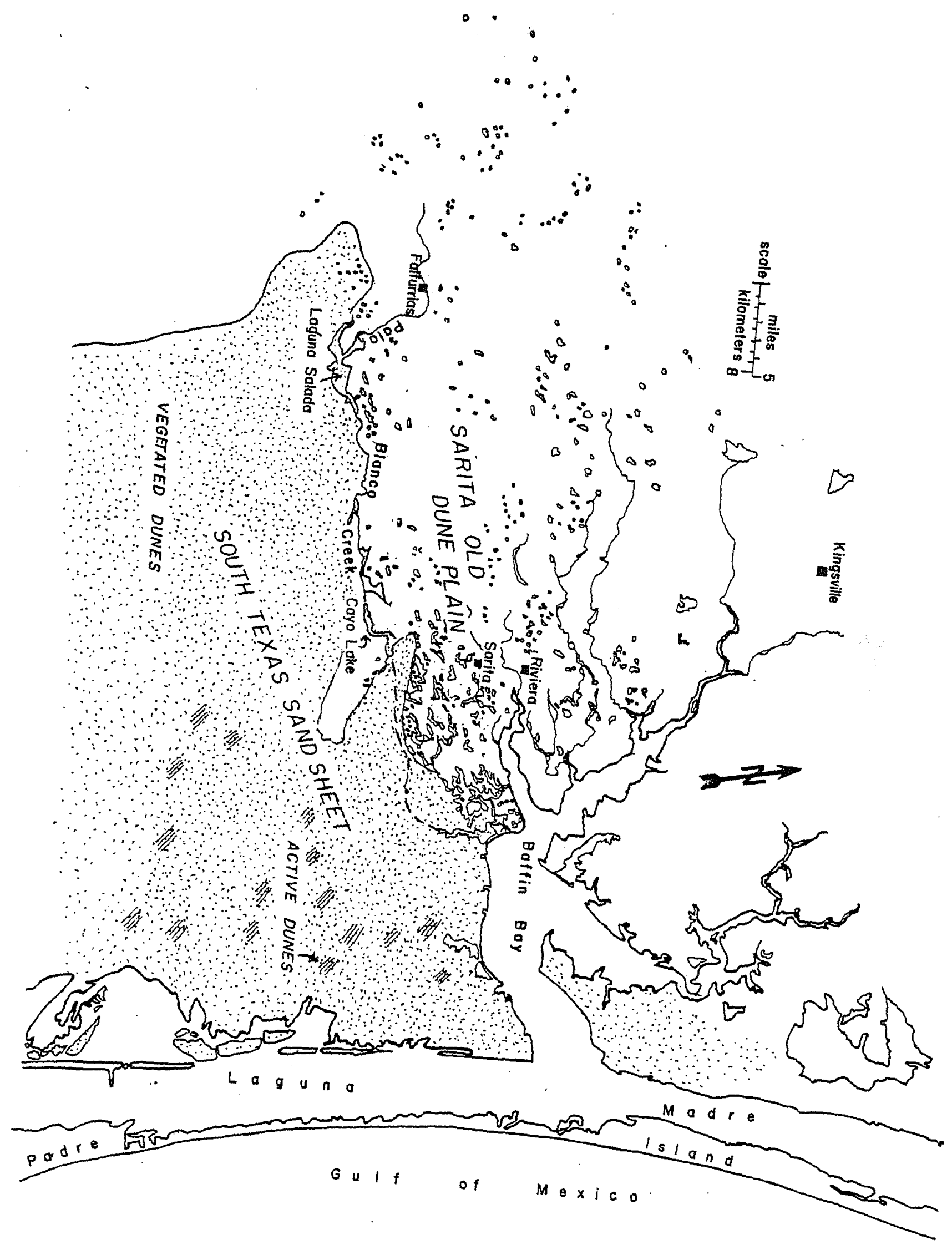


velocity layer. Satisfactory results were obtained by using 8-foot $(2.4 \mathrm{~m})$, 10 -foot $(3.0 \mathrm{~m})$ or 12 -foot $(3.6 \mathrm{~m})$ geophone spacings. Blasting caps provided the sound source, and in some instances two blasting caps were detonated simultaneously for signal enhancement.

Two lines of seismic sections were run at right angles to the course of the Palo Blanco River (Fig. 2), one approximately one half mile $(0.8 \mathrm{~km})$ long and another about one quarter mile $(0.4 \mathrm{~km})$ in length. Four strata were recognized from seismic velocity differences and their thicknesses and lateral relationships determined (Fig. 7). The configuration of these strata in cross section is evidence that the depositional sequence in which the bones are buried is fluvial in origin. Undulatory contacts at the boundaries of the strata are interpreted as river scour and fill structures characteristic of stream terraces (for an analogue see Willimon 1972).

The existence of laterally extensive alluvium indicates the Palo Blanco was once a broad meandering river (Fig. 7). Today, the Palo Blanco River is, except after heavy rains, inactive. The channel has filled with sediment, perhaps during the hypothesized "great drought" or Altithermal which followed the Late Wisconsin glacial advance (Antevs 1955,1962; Quinn 1957b). Considerable controversy surrounds the validity of the "Altitherma1." Pollen studies for the Trans-Pecos Texas area and for central Texas by Bryant (1970) generally confirm that aridity began around 8000 B.P. perhaps lasting as late as 4000 years ago. In the southwestern United States perennial streams became ephemeral earlier (about 12,000 B.P.) in correspondence to dwindling glacial stages of the Late Wisconsin (Haynes 1971; Denton 1970).

During the Altithermal, the climate of south Texas may have shifted toward aridity and temperatures probably increased. Stream discharges were significantly reduced and the Palo Blanco became intermittent or ephemeral. As precipitation continued to decrease, the vegetation flanking the river thinned, exposing sediments to erosion. Under these conditions runoff from the land supplied sediment to the river, causing high depositional rates. Reworking of previously deposited alluvial sediments in the old stream channel was minimal.

Concurrent with increased aridity was the growth of the South Texas Sand Sheet which directly affected the drainage of the Palo Blanco River. Quartz sand derived from Padre Island and the Pleistocene Ingleside Barrier Island was blown northwestward to the point of encroachment over some parts of the Palo Blanco River. Sand lobes, two of which are indicated in Figure 6, created dams across the channel of the Palo Blanco River, effectively backing up water in several places. Behind these dams of windblown sand, short segments of the Palo Blanco River are preserved and recognizable. Additional evidence for extinction of the Palo Blanco River by sand encroachment in the area of the mammoth discovery is a one- to twofoot $(33-66 \mathrm{~cm})$ layer of aeolian sand that overlies alluvial deposits. Alluviation of the Palo Blanco River channel, in part aided by growth of the South Texas Sand Sheet, occurred during the dwindling stages of the Wisconsin glacial stage (ca. 20,000 years B.P.) and culminated during the Altithermal. 

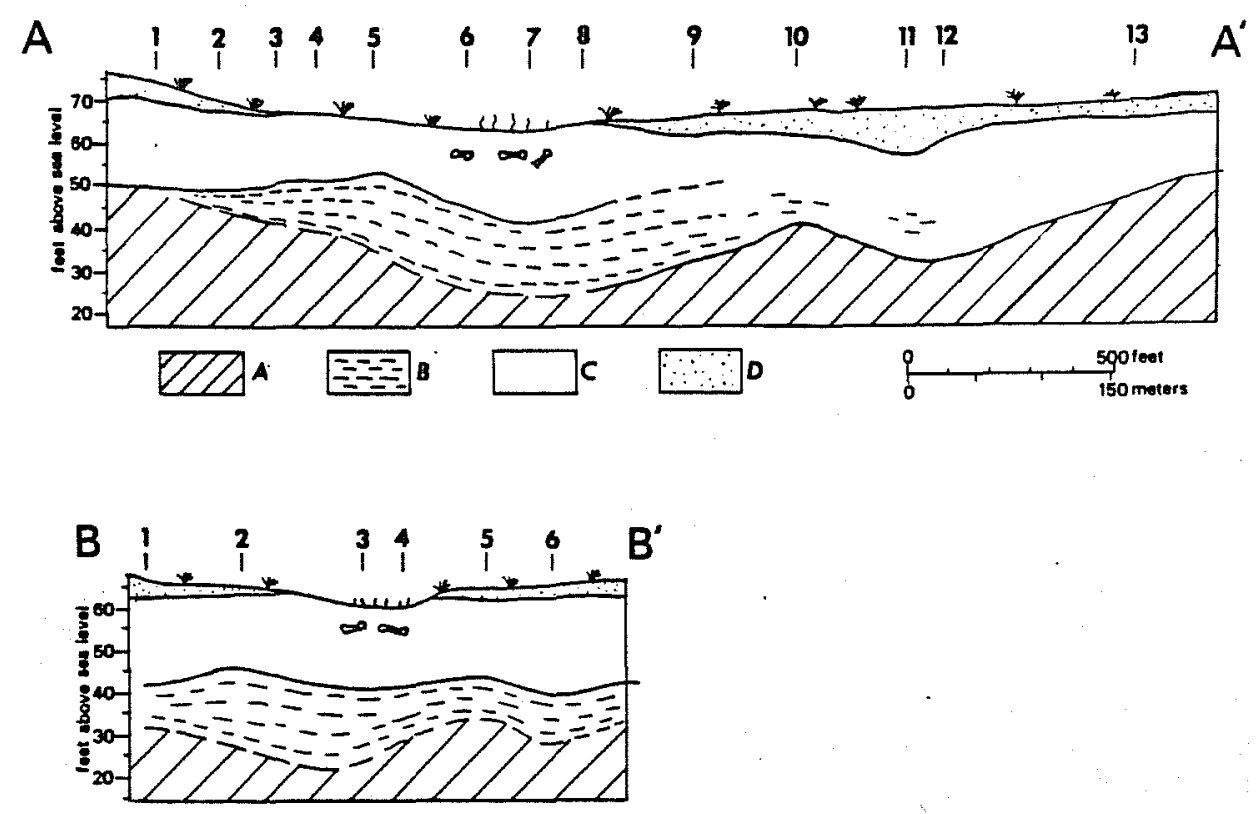

Figure 7. La Paloma Site. Seismic cross sections $A-A^{\prime}$ and $B-B^{\prime}$ extending at right angles to the present day, yet obscure, course of the $\mathrm{Pa} 10 \mathrm{Blanco}$ River. Numbers at the top refer to seismic stations. Vertical scale exaggerated. $A=$ Beaumont Clay (Pleistocene) where velocities exceed $4300 \mathrm{ft} / \mathrm{sec} ; \quad B=$ sandy clay, possibly $T^{l}$ where velocities are between 2600 and $4300 \mathrm{ft} / \mathrm{sec} ; C=$ clayey sand alluvial terrace $T^{0}$ where velocities range from 1050 to $1500 \mathrm{ft} / \mathrm{sec} ; D=100$ se wind blown sand with velocities less than $1000 \mathrm{ft} / \mathrm{sec}$. 


\section{Stratigraphy}

The vertical succession of sediment in the obscure course of the Palo Blanco River was investigated in stock tanks, trenches, test pits and cores (Fig. 2). Five trenches oriented at right angles to the relict course of the river as well as parallel to it were dug by a backhoe. The deepest trench was about 12 feet $(3.7 \mathrm{~m})$. Eight cores proximal to the trenches were obtained to a maximum depth of 11 feet $(3.9 \mathrm{~m})$ using a Giddings hydraul ic rotary core unit model GSRP-ST.

Stratigraphic units discernible in tanks, trenches and cores were sampled, measured and photographed (Fig. 9). The sedimentary material to depths of 6 feet $(1.8 \mathrm{~m})$ at sites $7-4$ (Fig. 2) is a poorly sorted mixture of clay, silt, sand, granules and secondarily-introduced caliche. Granule to cobble-sized caliche occurs in discontinuous bands following the contour of the land surface as shallow as a few feet $(65 \mathrm{~cm})$ under the surface but tends to be more abundant at greater depths. Caliche zones reflect past water table levels and are generally unreliable for correlation of strata in the area of fossil occurrences.

A typical sedimentary succession, from the surface downward, includes one foot $(30 \mathrm{~cm})$ of wind-blown sand, a foot $(30 \mathrm{~cm})$ of soil, and thick homogenous clayey sand which is partly calichified (Fig. 8, see T2). The one-foot deep soil is darker than sediment above and below and characteristically weathers into prismatic blocks a few inches $(5 \mathrm{~cm})$ wide. The underlying sediment is poorly stratified and deceptively appears to represent a single episode of deposition. However, the sedimentary sequence is interrupted by a dark-colored clay-rich zone containing finely disseminated plant and iron compounds at a depth of from 3 to 5 feet $(0.9$ to $1.5 \mathrm{~m}$ ) from the surface at sites 1,2 and 3 . This horizon is interpreted to be an ancient soil complex (paleosol) reflecting a time in the history of the Palo Blanco River when flow ceased, plant cover developed over its alluvium and mudcracks developed. This soil surface was buried by later alluvial material and sand filled the mudcracks when the flow of water resumed (Fig. 8).

The alluvial fill of the Palo Blanco River is very similar texturally wherever it was sampled, with the exception of the paleosols. Lateral changes of the texture of the sediment were only observed in the vicinity of site 2, where nearly pure sand lenses, reminiscent of channel center sands, were encountered at a depth of from 6 to 8 feet $(1.8$ to $2.4 \mathrm{~m})$. The location of the buried channel sands corresponds with the present-day course of the Palo Blanco. In the area under study, the thickness of the alluvial fill of the Palo Blanco River ranges from 13 feet $(3.9 \mathrm{~m})$ to 25 feet $(7.6 \mathrm{~m})$ based on seismic data. Characteristically, the alluvial fill becomes thinner away from the main channel (Fig. 7).

The contact between the alluvium and the much older Beaumont Clay (Pleistocene) on which it rests is considered to be erosional (Fig. 7). The uppermost part of the Beaumont Clay is a paleosol, composed of brown to red sandy clay and a dense accumulation of caliche nodules (Suhm 1974). Beneath this paleosol, the Beaumont is a dominantly yellow brown, poorly indurated sandy clay that was deposited in fluvia1-deltaic systems (Price 1933,1958; Aronow 1971). Caliche nodules are prominent at various stratigraphic horizons in the Beaumont and occur in various sizes and shapes, but most are elongate and have the appearance of root casts. Fossil mammoth, bison, horse and turtle have been observed locally in the Beaumont (Suhm 1974). 

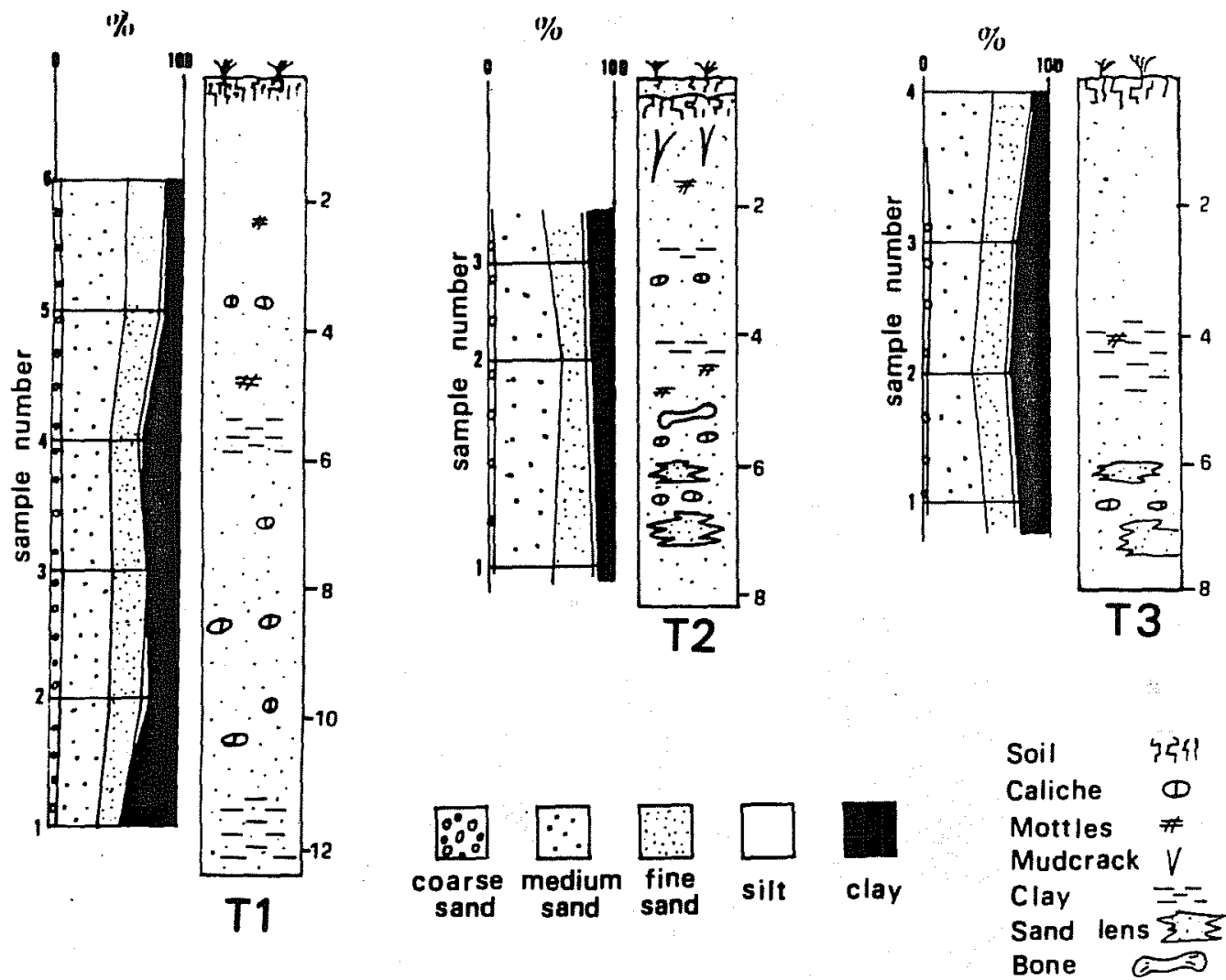

Figure 8. La Palama site. Columnar sections for trenches indicated in Fig. 2 showing the nature of the sedimentary material (Unit $C$ of Fig. 7 ) in which the bones are enclosed. Depths are in feet below the surface. Percentage of clay, silt, and fine-medium-coarse sand in relation to depth is shown to the left of the columnar sections. 


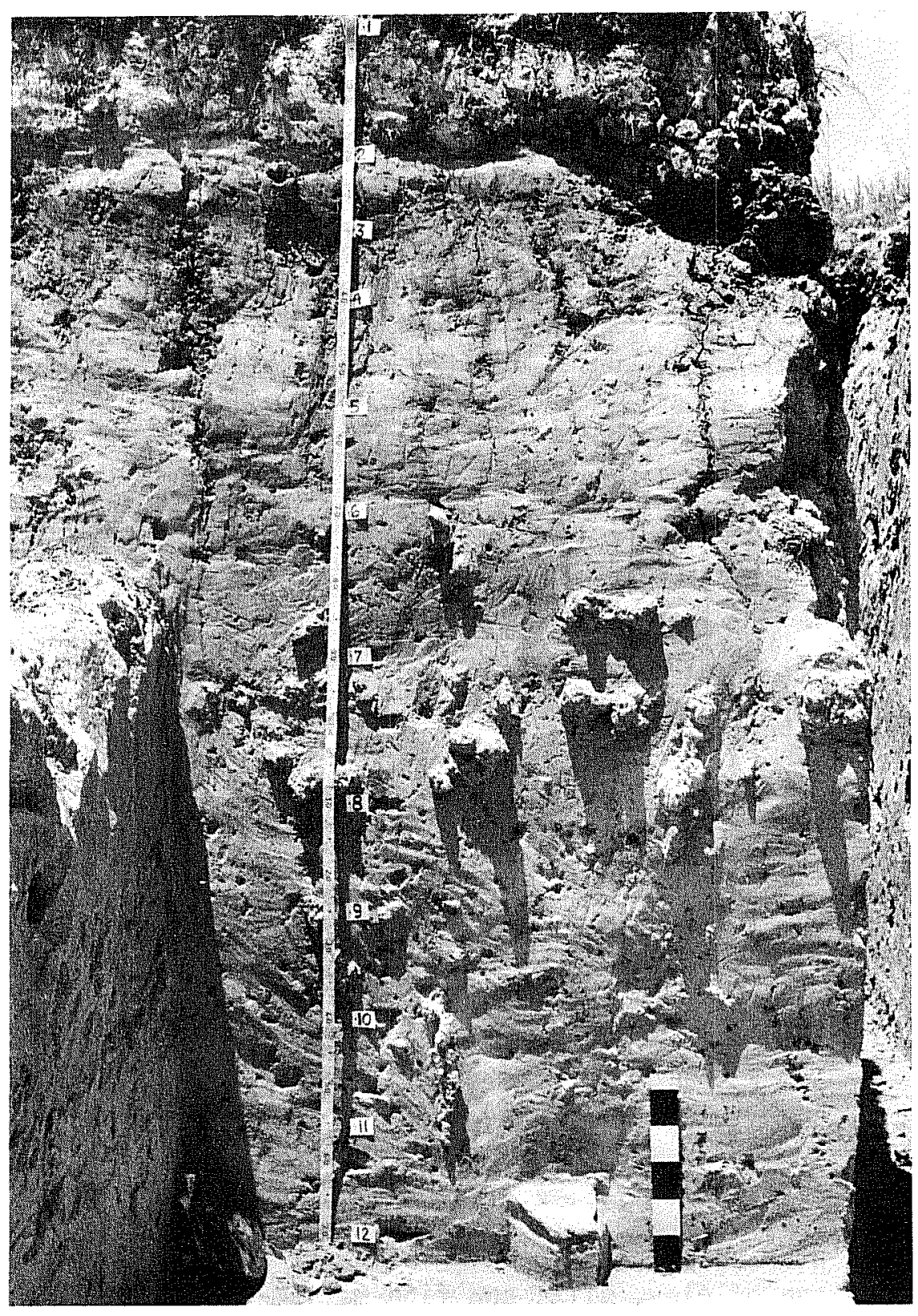

Figure 9. La Paloma site. Smoothed vertical north wall of Trench 2 (see Fig. 2 for location) showing, from top to bottom, one foot of aeolian sand (above level 1), recent buried soil horizon (between levels 1 and 2), and clayey sand alluvium with scattered caliche pebbles which stand out in relief (below level 2). Height of section is $5^{\prime} 9^{\prime \prime}(170 \mathrm{~cm})$. Farther down, but not exposed, is a paleosol and bone-bearing clayey sand. This stratigraphic section is typical of those that occur in the general area. 
Sedimentology

Analys is of Palo Blanco alluvium was accomplished by macroscopic and microscopic examination and by sieving. Clay, silt, sand, granules and pebbles compose the sediment. Quartz predominates in the sand fraction, and feldspar is present in amounts up to 5 per cent with even lesser amounts of heavy minerals such as tourmaline, zircon and magnetite. In the pebble fraction quartz dominates, with lesser amounts of chert and volcanic rock fragments. The assemblage of materials is consistent with those in a fluvial environment (Friedman 1961; Folk 1968).

Mineralogical uniformity of the stratigraphic units in the alluvium suggests the material was eroded from a common source. The dominance of sand over clay in Palo Blanco alluvium points to bedrock (probably sandstone) covered by immature soil. At the stratigraphic level of the vertebrate fossils, chert and volcanic rock fragments were found in thin zones in the alluvium. This material is derived from a source area of diverse lithologies, including Pleistocene and Tertiary-aged Lissie Sand, Leona Gravel and Sand and the Uvalde Formation (Plummer 1933). These formations have wide outcrop bands paralleling the Texas coast and were principal suppliers of sedimentary material to the Palo Blanco River at one time. Much of the chalcedony in the pebble fraction was derived from the Oakville Formation (Miocene); tuff and volcanic rock fragments may have been derived from the Catahoula Tuff (Miocene).

Grain size distribution analysis are useful in determining the environment of deposition of sediments (Folk and Ward 1957; Friedman 1961,1967). Thirteen samples were collected from trenches adjacent to site 2 for grain size evaluation. Grain size analysis was initiated by dispersing the sample by water and wet sieving samples through a 325 mesh $(0.03 \mathrm{~mm})$ screen to separate clay and fine silt from 'sand. The clay and fine silt that was washed through the screen was retained in buckets and dried. The fine silt and clay fractions were separated by differences in settling rates and each was weighed. Grain size determination of the sand fraction using sieves at $1 / 4$ phi intervals was made by conventional methods outlined by Folk (1968). The relative percentages of standard textural classes (sand, silt and clay) were then determined and plotted graphically (Fig. 8).

Most of the sediments are clayey sands. The median grain size of the sediment at the level of the bones is $0.11 \mathrm{~mm}$ (very fine sand). This type of sediment is consistent with the energy and hydraulics of the river environment (Folk and Ward 1957). Skewness ranged from +0.7 to +0.8 with an average of +0.76 , which is indicative of the presence of large amounts of fine grained material. This characteristic is indigenous to river sands because the amount of mud in a river commonly is greater than the amount of sand, and fine particles that were carried in suspension became trapped between the coarser grained particles in the waning stages of flow (Friedman 1961,1967).

Sorting (standard deviation of Folk and Ward 1957) is 0.68 to 3.67 for the La Paloma samples with an average of 2.30 . These high values indicate a poorly sorted sample characteristic of river sediments (Friedman 1961). Poor sorting may result when the rate of supply of material is greater than the efficiency of the sorting agents and when the fine-grained fraction, which cannot be deleted from the river load, is available for deposition with the sand fraction. 
On the basis of textural evidence, the environment of deposition of the bone-bearing material is fluvial. A lacustrine environment is precluded on the basis of poor sorting, positive skewness and lack of definitive stratification. Unconsolidated sand in the upper parts of most of the sections is considered to be aeolian in origin in consideration of statistical analys is of grain size distribution and proximity to the South Texas Sand Sheet.

\section{Paleontology}

The La Paloma fossils are concentrated within a narrow, shallow stratigraphic interval of alluvium from 4 feet $(1.2 \mathrm{~m})$ to approximately 7 feet $(2.1 \mathrm{~m})$ under the surface and apparently are laterally continuous in the area of the stock tanks. The Late Pleistocene megafauna includes Mammuthus columbi, Equus sp., Bison antiquus, Paramylodon sp., mastodon, glyptodon and deer.

At site 1 a total of 145 bones from a partly articulated mammoth (Figs. 3, 5) was recovered during the 1975 excavations. These bones were relatively undisturbed by moving water or scavengers after death of the mammoth and were perhaps rapidly buried. A centrally-located mass of articulated and disarticulated ribs and vertebrae was between the last mandible and pelvis, and the mandibles were near the scapula. The atlas was out of position, near the posterior vertebrae and pelvis (Figs. 3, 5). The right tusk and an adjacent upper molar were six feet $(2 \mathrm{~m})$ west of the center of the main bone array. The left tusk and part of the sku11, except one of the upper molar series, were accidentally removed by heavy earth-moving machinery during the discovery of the mammoth. Bones of the forelimbs were scattered to a distance of about 18 feet $(6 \mathrm{~m})$ from the main array. A femur was closer to the array, about six feet $(2 \mathrm{~m})$ southwest of the pelvis. At site 2 , molars and a femur of another mammoth were uncovered but not removed. The shallowest occurrence of mammoth molars was at a depth of 2.3 feet $(70 \mathrm{~cm})$ in Trench 2 . The molars were fragmented and worn, evidently the result of reworking in river sediments.

A ground sloth, Paramylodon harlani, from site 1 is represented by a right mandibular ramus with teeth, isolated incisors and several vertebrae. An articulated skeleton similar to Bison antiquus, described by Skinner and Kaisen (1947:178) and Lundelius (1972), was partially unearthed at site 2. Unfortunately, rains filled site 2 before any part of the bison could be excavated. Molars and a few post cranial elements of horse, Equus sp., were uncovered at sites 2, 3 and 4 . A mastodon is represented by a sma 11 tooth fragment recovered from matrix material surrounding mammoth bones at site 1 . Hexagonal scutes of a glyptodon, molars belonging to a horse and mammoth and a deer antler tip were recovered from backdirt material adjacent to a stock tank referred to as the "fishing pond" (Fig. 2) dug in 1955 at a depth similar to site 1.

Faunas at La Paloma are similar to those reported from Ingleside, Texas (Lundelius 1972). Tapirs and carnivores, such as coyotes, dire wolf and saber tooth cats have been reported from Ingleside (Lundelius 1972; Sellards 1940; Quinn 1957a) but not from La Paloma. Perhaps, with additional investigation, those will be uncovered. The Ingleside faunas occur in pond deposits of undetermined age superposed on lagoonal deposits referred to as the Ingleside Lagoonal Complex (Price 1933, 1958). 
Microfauna and Small Megafauna. Among the smaller fossil material retrieved from the La Paloma excavations are rounded bone fragments which originated by water transport an unknown distance from their point of origin or by large animals crushing exposed bone near or in the river. It is estimated that five small bone fragments (approximately $1 \times 2 \mathrm{~cm}$ ) exist per 50 cubic centimeters of sediment at the stratigraphic level of the bone arrays.

In the summer of 1976, thousands of sma11, whole and fragmented bones belonging to small animals were recovered from test pits and trenches east of site 2 by washing sediment through 1/4-inch $(6 \mathrm{~mm})$ mesh screens. A large portion of this bone could only be identified to broad taxonomic categories. At depths of 4.0 to 6.5 feet $(1.4$ to $1.9 \mathrm{~m}$ ) in a position directly adjacent to Trench 2 (Fig. 2), the assemblage primarily consisted of blade-like bone fragments from larger animals, vertebrae (some articulated) and ribs of reptiles (probably snake) and crab ossicles and appendages (Allan Chaney, personal communication 1976). Aquatic and terrestrial snails, cycloid fish scales and vertebrae of fish and amphibians occurred in lesser amounts. The aquatic snails were Biomphalaria havanensis and Physa virgata (Raymond Neck, personal communication 1976) which are known to 1 ive in ponds and streams with reduced water currents and varying water quality. The entire microfaunal assemblage is suggestive of a semi-stagnant but oxygenated aqueous habitat with moderate to low water velocities. The presence of crabs indicates brackish water.

Vegetation. Brown to black fingernail-sized masses of decomposed woody fibers are dispersed in the alluvium. Much of the plant material has been destroyed by postdepositional solution and oxidation. Plant material, concentrated in paleosols containing higher amounts of clay, was discovered immediately above the level of the bones at sites 1, 2 and 3. Some of the disseminated woody material served as nuclei around which caliche formed pseudomorphs of root casts.

Approximately three pounds of sediment samples were collected at the level of the bones at site 1 for pollen analysis. The samples were void of pollen, perhaps due to severe oxidation and high alkalinity ( $\mathrm{pH} 8$ ) of the matrix (Vaughn $M$. Bryant, Jr., personal communication 1976).

Archaeological Materials

Lithic materials were collected from the surface of backdirt piles surrounding both sides of the stock tanks at sites 1-4 (Fig. 2). They had been exposed by rains during June of 1975 . It should be emphasized that these artifacts were not in direct association with any of the fossil remains described earlier in this paper.

Some of the artifacts have been previously discussed in Suhm (1978), and some apparent errors in identification were made (e.g., no Folsom points are known from the site). At site 1 , the following artifacts were found (all in disturbed backdirt contexts): a chert uniface (possibly a scraper), two bipointed projectile points (possibly of the Lerma type; see Fig. 10,a,b), an exhausted conical core (with wear damage indicating secondary use as a scraper) and several chert (flint) flakes. 


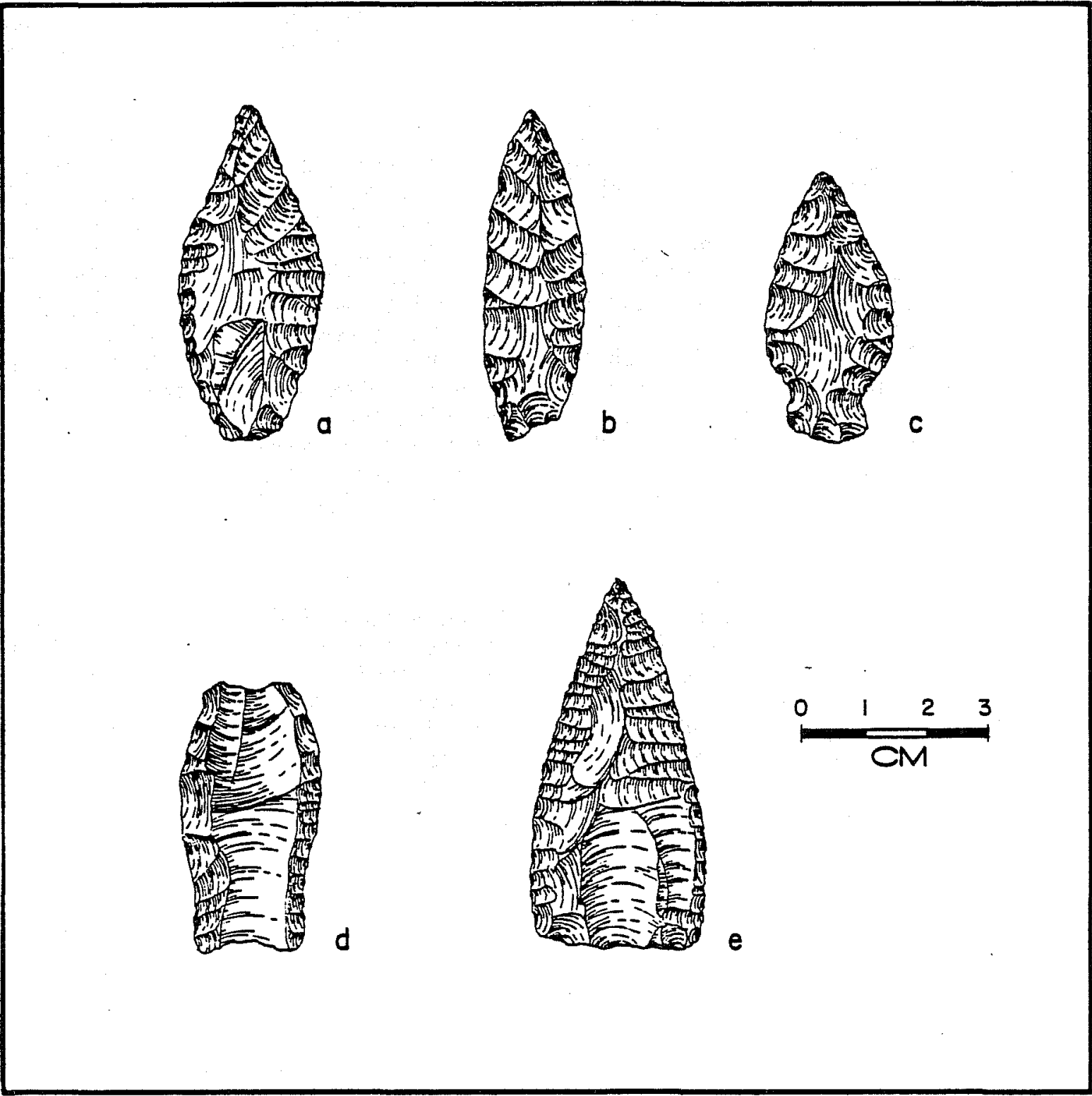

Figure 10. Projectile Points from the La Paloma Site. Drawings by Kathy Bareiss, Center for Archaeological Research. 
The backdirt accumulations at site 2 yielded several projectile points, including Palmillas (Fig. 10,c), Nolan (identified by Curtis Tunne11, personal communication 1976; not available for examination at the time of this writing) and a shouldered lanceolate specimen (Fig. 10,d). This specimen is of interest, as it resembles shouldered Late Paleo-Indian projectile points reported from site 4I VT 15 in Victoria County (Birmingham and Hester 1976) and from 41 LK 28 in Live Oak County (Charles Johnson II, personal communication). However, there is no dulling of the lower lateral edges or of the base, a trait often found on Paleo-Indian projectile points in the region. The proximal portion of the point has been basally thinned by the flute-like flakes on both faces; in addition, there are impact "flutes" at the distal end.

The backdirt at site 3 yielded chert flakes. At site 4 , a triangular point (Fig. 10, e) was found in the backdirt. It may fit within the Tortugas type. However, it has parallel-oblique flake scars on both faces, and the lateral edges are slightly denticulated as a result of this type of flake removal. It is very similar to "Early Triangular" points found in Pre-Archaic contexts in south central Texas (Hester 1971; Hester and Kohnitz 1975). Radiocarbon dates related to the latter part of the Pre-Archaic (or San Geronimo [Weir 1976]) period in which this type of triangular point occurs are ca. 3400-3600 B.C. (TX-3606; Hester, notes on 41 BX 277; TX-3912; Stephen Black, personal communication).

The archaeological situation at La Paloma is uncertain. The artifacts described here all appear to date from post-Pleistocene times (i.e., possible Late PaleoIndian through Archaic). Projectile points described as Lerma have been found associated with mammoth remains in the Valley of Mexico (Wormington 1957:97). However, the Lerma type is i11-defined and there is a wide range of bipointed projectile points in south Texas that are clearly of Archaic--not Pleistocene-age.

The Paleo-Indian period in southern Texas has been reviewed by Hester $(1976,1977$, 1979,1980). Clovis and Folsom points are found throughout the region (Hester 1977: Figs. 1,2), but none have yet been found in situ or associated with Pleistocene fauna. A Folsom campsite (41 BX 52), without associated faunal materials, has recently been excavated in San Antonio by archaeologists from the Texas Department of Highways and Public Transportation. The nearest site with Pleistocene fauna and definitely associated artifacts is Bonfire shelter in southwest Texas (Dibble and Lorrain 1967). Folsom and Plainview points occur in bone bed 2 at that site, the result of Paleo-Indian bison drives. The Buckner Ranch site (Sellards 1940; Hester 1976) in Bee County is roughly 100 miles north of La Paloma. Late Pleistocene fauna and possibly associated artifacts and campsite materials were found; unfortunately, the context of these finds remains unclear. Two sites with mammoth remains and possibly associated flakes were reported during fieldwork at Falcon Reservoir (Cason 1952). In genera1, however, most elephant remains on the south Texas coastal plain have been reported in reworked sediments as secondary depositions.

Late Paleo-Indian projectile points, such as Plainview, Golondrina and Angostura are fairly common, al though campsites of this period are known only from adjacent south central Texas (the St. Mary's Hall Plainview site; Hester 1979) and southwest Texas (the Baker Cave site, with a Golondrina stratum; Hester 1979). 
Efforts were made to locate a Paleo-Indian kill-site at La Paloma in summer, 1976. The excavations, under the direction of Herman Smith, consisted of test pits and trenches (Fig. 2). The results were negative, in that no human cultural materials were found to be associated with any of the Late Pleistocene fossils. However, there are large areas of the locality containing abundant fossil remains that remain to be excavated.

\section{Age of the Deposits}

Four radiocarbon dates were obtained from bones and teeth unearthed in 1975 in alluvial material of the Palo Blanco River, at depths ranging from 5 to 6 feet $(1.5$ to $1.8 \mathrm{~m})$. Sam Valastro of the Radiocarbon Laboratory at Balcones Research Center, The University of Texas at Austin, Texas, performed the analyses. Carbonized material concentrated in scattered patches within the sediment at site 1 was sampled and designated TX-2193 and TX-2194 by the Radiocarbon Laboratory. A reliable age could not be determined, however, because of the very small amounts of carbon in the large samples of sediment.

Sample TX-2196, a mammoth bone fragment from site 1, provided a date of $9830 \pm$ 110 B.P. (7880 B.C.) from extracted collagen. Mammoth molars from the center of site 2 at a depth of 5.5 feet $(1.68 \mathrm{~m})$ were designated TX-2197. Enamel from these molars was dated at $8080 \pm 480$ B.P. (6130 B.C.), and the dentine had an age of $9380 \pm 4690$ B.P. (7430 B.C.). The large deviation for the dentine was due to a very small sample. The younger range of the date is more reliable. Sample TX-2195, also from site 2 at the same level as TX-2197, consisted of several large pieces of unidentified well preserved bone. Bone apatite was dated at.9560 \pm 120 B.P. (7610 B.C.), and the organic fraction (collagen) yielded an age of $9250 \pm 2280$ B.P. (7300 B.C.). The large deviation in the latter sample was due to small extraction of quantities of datable material.

The presence of in situ Late Pleistocene fauna at La Paloma is of great interest. The radiocarbon dates from the site raise problems in that they would, if taken at face value, suggest the late survival of certain Pleistocene species on the coastal plain. Suhm (1978:33) discusses this matter and reviews problems of Pleistocene faunal extinction relevant to. the La Paloma site.

\section{Acknowledgments}

The combined paleontological, archaeological and geological study of the La Paloma Mammoth site required the participation of many people. Interested individuals and groups from the south Texas area, including many college and high school students and teachers, assisted in many ways. Tom Wright, James Stockton, D.D.S., and June Suhm assisted in a professional capacity in the 1975 digs. Mrs. J. Picquet, Director of the Conner Museum at Texas A\&I University, helped with many of the logistic problems that arose at that time. Herman Smith and students under his direction contributed much information for the area east of the fishing pond during the summer of 1976.

Taxonomic identification was done by Drs. Quinn, Lundelius (The University of Texas at Austin) and Chaney (Texas A\&I University). 
Partial financial support for the geologic field investigation during the summer of 1976 was provided by a grant from Texas A\&I University.

Lastly, appreciation is extended to Mr. and Mrs. Fred Erck, owners of the La Paloma Ranch, for their full support and devoted interest in this project. Not only did they allow free access to their ranch but they also funded radiocarbon analyses and furnished air transportation to Austin for that purpose. The cooperation of Allen Mittag, the observant ranch hand who discovered the bones, and Roy Henry, manager of the La Paloma Ranch, is greatly appreciated. 


\section{REFERENCES CITED}

Antevs, E.

1955 Geologic-Climatic Dating in the West. American Antiquity 20(4):317335 .

1962 Late Quaternary Climates in Arizona. American Antiquity 28:193-199.

Aronow, S.

1971 Nueces River Delta Plain of the Pleistocene Beaumont Formation, Corpus Christi, Texas. American Association of Petroleum Geology, Bulletin 55:1231-1248.

Behrens, E. W.

1963 Buried Pleistocene River Valleys in Aransas and Baffin Bays, Texas. Publications, Institute of Marine Science, University of Texas 9: 7-13.

Birmingham, W. W. and T. R. Hester

1976 Late Pleistocene Archaeological Remains from the Johnston-Heller Site, Texas Coastal Plain. Center for Archaeological Research, The university of Texas at San Antonio, Survey Report 3:15-33.

Bryant, V. M., Jr.

1970 General Comments. In S. Valastro and E. M. Davis, University of Texas at Austin Radiocarbon Dates VII. Radiocarbon 12(2):625.

Cason, J. F.

1952 Report on Archeological Salvage in Falcon Reservoir, Season of 1952. Bulletin of the Texas Archeological Society 32:33-46.

Corpus Christi Geological Society

1958 Sedimentology of South Texas. Field Trip Guidebook, Gulf Coast Association Geological Society, Annual Meeting, Corpus Christi, Texas, October 27-November 1.

Denton, G. H.

1970 Late Wiscons in Glaciation in Northwestern North America: Ice Recession and Origin of the Paleo-Indian Clovis Complex. Abstract, First Meeting of American Quaternary Association:34-35. Bozeman, Montana. 
Dibble, D. S. and D. Lorrain

1965 Bonfire Shelter: A Stratified Bison Kill Site, Val Verde County, Texas. Texas Memorial Museum Miscellaneous Papers 1.

Folk, R. L.

1968 Petrology of Sedimentary Rocks. Hemphi11's Book Store, Austin, Texas.

Folk, R. L. and W. C. Ward

1957 Brazos River Bar, A Study in the Significance of Grain-Size Parameters Journal of Sedimentary Petrology 27:3-27.

Friedman, G. M.

19611961 Distinction Between Dune, Beach, and River Sands from Their Textural

Characteristics. Journal of Sedimentary Petrology 31:514-529.

1967 Dynamic Processes and Statistical Parameters Compared from Size Frequency Distribution of Beach and River Sands. Journal of Sedimentary Petrology 37:327-354.

Hay, 0. P.

1926 A Collection of Pleistocene Vertebrates from Southwest Texas.

- Proceedings, U.S. National Museum 68(14).

Haynes, C. V.

1970 Geochronology of Man-Mammoth Sites and Their Bearing on the Origin of the Llano Complex. In W. Dort, Jr. and J. K. Jones, Jr., eds., Pleistocene and Recent Environments of the Central Great Plains. University of Kansas, Department of Geology, Special Publication 3. University of Kansas Press, Lawrence.

1971 Time, Environment, and Early Man. Arctic Anthropology 8(2):3-14. Hester, T. R.

1971 Archeological Investigations at the La Jita Site, Uvalde County, Texas. Bulletin of the Texas Archeological Society 42:51-148.

1976 Late Pleistocene Aboriginal Adaptations in Texas. Center for Archaeological Research, The University of Texas at San Antonio, Special Report 3:1-14.

1977 The Current Status of Paleoindian Studies in Southern Texas and Northeastern Mexico. In E. Johnson, ed., Paleoindian Lifeways. The Museum Journal XVII:169-186. Texas Tech University, Lubbock.

1979 Early Populations in Prehistoric Texas. Archaeology 32(6):26-33. 
Hester, T. R. (continued)

1980 Digging into South Texas Prehistory. Corona Publishing Company, San Antonio.

Hester, T. R. and H. Kohnitz

1975 Chronological Placement of "Guadalupe" Tools. La Tierra 2(1):22-25.

Lundelius, E. L., Jr.

1972 Fossil Vertebrates from the Late Pleistocene Fauna, San Patricio County, Texas. Bureau of Economic Geology, Report of Investigations 77. University of Texas, Austin.

Plummer, F. B.

1933 Cenozoic Systems in Texas. In Geology of Texas, Volume 1, Stratigraphy. university of Texas Bulletin 3232:727-798.

Price, W. A.

1933 Role of Diastrophism in Topography of the Corpus Christi Area, Texas. American Association of Petroleum Geologists Bulletin 17:907-962.

1958 Sedimentology and Quaternary Geomorphology of South Texas. Gulf Coast Association Geological Society, Transactions 8:410-475.

Quinn, J. H.

1957a Pleistocene Equidae of Texas. Bureau of Economic Geology, Report of Investigations 33. University of Texas, Austin.

1957b Paired River Terraces and Pleistocene Glaciation. Journal of Geology 65:149-166.

Saunders, J. J.

1975 Late Pleistocene Vertebrates of Western Ozark Highland, Missouri. Unpublished Ph.D. dissertation, Department of Geosciences, University of Arizona, Tucson.

Sellards, E. H.

1940 Pleistocene Artifacts and Associated Fossils from Bee County, Texas: New P7iocene Mastodon. Geological Society of America Bulletin 51: 1627-1664.

Skinner, M. F. and 0. C. Kaisen

1947 The Fossil Bison of Alaska and Preliminary Revision of the Genus. American Museum of Natural History Bulletin 89:131-256. 
Suhm, R. W.

1974 Shoreline and Beach Sediment Characteristics of Western Baffin Bay, Texas. TAIUS, Journal of Texas A\&I University VII:3-27.

1978 Preliminary Investigation of the La Paloma Mammoth Site (Late Pleistocene), Kenedy County, Texas. TAIUS, Journal of Texas A\&I University $X I(1): 13-36$.

U.S.D.A.

1960 Soil Map of Kenedy County, Texas. Soil Conservation Service (U.S.D.A.) and Texas Agricultural Experimental Station, August. Compiled by G. E. Frank.

Weir, F. A.

1976 The Central Texas Archaic. Unpublished Ph.D. dissertation, Department of Anthropology; Washington State University, Pullman.

Willimon, E. L.

1972 New Local Faunas and Paleoecology (Pleistocene) of North Central Texas. Texas Journal of Science 23:449-469.

Wormington, H. M.

1957 Ancient Man in North America. Fourth edition. Denver Museum of Natural History, Popular Series 4. 


\section{CHANGING SALINITY IN BAFFIN BAY, TEXAS, AND ITS POSSIBLE}

\section{EFFECTS ON PREHISTORIC OCCUPATION}

Thomas R. Hester

The major estuary on the southern Texas coast is Baffin Bay (and its northern extension, Grul10 Bay) in Kleberg and Kenedy Counties (for location of Baffin and Grullo Bays, see Fig. 1 in Highley, this volume). According to Behrens (1963:9), Baffin Bay "has al1 the characteristics of an estuarine bay except that the associated streams are small and often dry. The form of Baffin Bay is actually closer to a river valley system than is the form of any of the other large estuarine bays (on the Texas coast)." Baffin Bay is also a hypersaline system, although the evidence suggests that it has not always been so. The purpose of this brief paper is to examine, in a preliminary fashion, the possible effects that changing salinity patterns in the Baffin-Grullo Bays system may have had on prehistoric settlement.

Archaeological research in the areas around Baffin and Grullo Bays has been sporadic. A number of sites have been recorded along the margin of Grullo Bay (Hester 1969, 1971), but only a few sites are known from Baffin Bay proper (Hester 1969). As outlined in Hester (1971), most occupation sites are situated along the shores of Grullo Bay, usually atop clay dunes or at the confluence of a tributary and the bay. Aside from these occupation sites, there are also mortuary or cemetery sites, and surface scatters around the fringes of ephemeral lakes on the inland prairies. Unfortunately, sites in the interior of Kleberg and Kenedy Counties are not well known (cf. Hester 1973). The problem of defining prehistoric settlement and subsistence patterns in the region has been dealt with in a preliminary fashion (Hester 1971), but such studies are complicated by the lack of a sound, local chronology. We do not yet fully understand the nature of the occupations at the recorded bayshore sites. Are these the camping loci of small groups of people who frequented the bayshore habitat the year-round? Or, were the sites visited as a part of seasonal or yearly economic cycles by peoples who lived part of the year elsewhere (perhaps in the interior or on other nearby sectors of the littoral)? While we cannot satisfactorily examine these questions in this paper, I would like to discuss some data, derived from research by marine biologists, which may have a distinct bearing on any future settlement-subsistence investigations in the area.

During the 1950's, marine biologists working in this area were of the opinion that the Baffin-Grul10 system enjoyed low salinity (brackish) conditions until relatively recent times, when increased salinity was brought about largely by reduced annual precipitation (Breuer 1957:138). This hypothes is was based largely on the occurrence of oyster shells in middens along the bay shore. It was also believed that the deposition of heavy loads of silt on the bottom of Grullo Bay accompanied rising salinity (the increased siltation resulting probably from the destruction of the surrounding watershed through overgrazing). The muddy bottom characterizing Grullo Bay at present (and in the recent past), coupled with high salinity, cannot support oyster populations. The oysters in the middens surrounding the bay were thus attributed by marine biologists to a period prior to the hypersaline/muddy bottom conditions of the mid-20th century--conditions which they thought came about during the historic era. However, recent research 
(particuTarly by E. W. Behrens) indicates a completely different history of saline conditions in the bay system. Behrens (1971:279; 1972:467) has discovered, through a series of geologic radiocarbon assays, that Baffin Bay and the Laguna Madre were cut off from the Gulf of Mexico about 5000 B.P. and that hypersaline conditions commenced in the bays around 4000 years ago (i.e., ca. 2050 B.C.). Additional radiocarbon evidence, from serpulid worm reefs in the bay, indicate that this hypersaline situation persisted into historic times. Hypersalinity ended the status of Baffin and Grullo Bays as normal estuaries, and drastically reduced molluscan fauna supported by the bay waters. According to Behrens (personal communication), this indicates that archaeological sites containing a shell assemblage characteristic of a normal estuary with the proper saline balance would be at least 4000 years old--if the shells were gathered from Baffin and Grullo Bays. Behrens has examined the list of shellfish present at the Loyola Beach site (Hester 1971) and is of the opinion that this assemblage would have to have been collected under normal estuary conditions, prior to 4000 B.P. The mollusca include Oyster, Southern Quahog, Heart Cockle, Sunray Clam, Bay Scallop and Lightning Whelk (conch). Of course, some of these specimens could have been collected from the Gulf of Mexico, about 20 miles to the east of the Loyola Beach site. This may be particularly true in the case of the conch and Sunray Clam, both of which were used as sources of raw materials for tool manufacture. There are cultural remains at Loyola Beach which would indicate an Archaic or preceramic occupation which could possibly date prior to 4000 B.P. and these peoples could have been responsible for gathering the shellfish described above. However, the bulk of the occupational debris appears to be linked to Late Prehistoric occupations characterized by ceramics and arrow points.

With Behren's data, one could use the occurrence of normal-salinity shell fauna to indicate the presence of pre-4000 B.P. human occupation of archaeological sites. Another "time-marker" revealed through Behren's work (see also Suhm, Russe11 and Russel1 1977:22) may be the occurrence of serpulid worm tubes. These occur at many Grul10 Bay sites; Behrens believes that the growth of serpulid worm tubes in the bay begins after 3000 B.P. (cf. Behrens 1972:468).

I would like to offer the following generalized hypotheses based on what we currently know about salinity changes in the bay system. These can be tested by further research by archaeologists and marine biologists in the area:

1. The main occupation sites, with extensive surface debris, often situated on high clay dunes and containing several species of shellfish characteristic

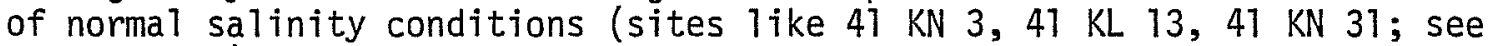
Hester 1969) were originally inhabited prior to ca. 2000 B.C. In fact, the bulk of occupation at these sites may have been during that time period. The occupants of these sites relied heavily on shellfish-collecting, supplementing the diet provided by these mollusca through hunting and food-collecting on the inland prairies and the exploitation of seasonal waterfowl/fish harvests. occupation of these sites could have spanned several months.

2. In the period since ca. 2000 B.C., the gathering of shellfish in any quantity has been impossible in this area due to the hypersaline conditions. The subsistence pattern expanded so as to place more emphasis on fishing and/or on inland hunting and foraging. Seasonal waterfowl and fish harvests continued. 
3. The major occupation sites of post-2000 B.C. were located at the confluence of tributaries with the bays; these may have been seasonally-occupied sites, with habitation correlated with fish "runs" (see Hester 1971). These sites might be recognized by large numbers of the otoliths and bones of Black Drum (Pogonia cromis). Today, the "runs" of this fish species occur during the period of January to March.

4. The bayshores did not see long-term occupations after 2000 B.C., particularly because of restricted shellfish resources. Groups may have visited the bayshores during annual subsistence rounds. Perhaps the distribution of certain Late Prehistoric specialized tool forms, such as olmos bifaces (Shafer and Hester 1971) may hold a clue to the annual travels of certain groups. For example, the olmos bifaces are confined largely to an area extending from the Grullo Bay area, inland along the major stream course, Los 01mos Creek, and its tributaries. This would suggest that a group or groups may have traveled up and down this drainage from the interior to the coast, throughout the course of a subsistence cycle. 


\section{REFERENCES CITED}

Behrens, E. W.

1963 Buried Pleistocene River Valleys in Aransas and Baffin Bays, Texas. Publication of the Institute of Marine Science, The University of Texas 9:7-18.

1971 The Development of Hypersal inity in Baffin Bay, Texas (abstract). The Texas Journal of Science 22(2-3):279.

1972 Baffin Bay Marl and Shell Samples, Texas. In S. Valastro, Jr., E. Mott Davis, and Alejandra G. Varela, University of Texas at Austin Radiocarbon Dates IX. Radiocarbon 14(2):466-468.

Breuer, J. P.

1957 An Ecological Survey of Baffin and Alazan Bays, Texas. Publication of the Institute of Marine Science, The University of Texas 4(2): 134-155.

Hester, T. R.

1969 Archeological Investigations in Kleberg and Kenedy Counties, Texas in August, 1967. State Building Commission, Archeological Program 15.

1971 Loyola Beach: An Example of Aboriginal Adaptation to the Maritime Environment of the Lower Texas Coast. Florida Anthropologist $24(3): 9 ;-106$.

1973 Notes on an Archaeological Site in Kleberg County, Texas. Newsletter, Houston Archeological Society 41:2-6.

Shafer, H. J. and T. R. Hester

1971 A Study of the Function and Technology of Certain Bifacial Tools from Southern Texas. Texas Historical Survey Committee, Archeological Report 20.

Suhm, R. W., J. L. Russell and J. M. Russe11

1977 Geomorphic and Biologic Changes in the Drum Point Spit and Other Regions of Baffin Bay, Texas. TAIUS, Journal of Texas A\&I University $X(1): 9-27$. 